\author{
UNIVERSIDADE DE SÃO PAULO \\ ESCOLA DE ARTES, CIÊNCIAS E HUMANIDADES \\ PROGRAMA DE PÓS-GRADUAÇÃO EM CIÊNCIAS DA ATIVIDADE FÍSICA
}

DIEGO LEONARDO DE ANDRADE

Análise Histórica da Evolução dos Sistemas Defensivos no Basquetebol

Brasileiro Masculino Adulto

São Paulo

2019 
DIEGO LEONARDO DE ANDRADE

\title{
Análise Histórica da Evolução dos Sistemas Defensivos no Basquetebol
} Brasileiro Masculino Adulto

\author{
Versão Corrigida
}

Dissertação apresentada à Escola de Artes Ciências e Humanidades da Universidade de São Paulo para a obtenção do título de Mestre em Ciências, pelo programa de Pós-Graduação em Ciência da Atividade Física.

Área de Concentração:

Ciências Biológicas e da Saúde

Orientado Por:

Prof.: Dr. Dante De Rose Jr.

São Paulo 
Autorizo a reprodução e divulgação total ou parcial deste trabalho, por qualquer meio convencional ou eletrônico, para fins de estudo e pesquisa, desde que citada a fonte.

Andrade, Diego Leonardo de

Análise histórica da evolução dos sistemas defensivos no Basquetebol Brasileiro Masculino Adulto / Diego Leonardo de Andrade ; orientador, Dante De Rose Jr. - 2019.

152 f.: il.

Dissertação (Mestrado em Ciências) - Programa de PósGraduação em Ciências da Atividade Física, Escola de Artes, Ciências e Humanidades, Universidade de São Paulo, São Paulo.

Versão corrigida

1. Basquetebol - Brasil. 2. Basquetebol - Aspectos históricos - Brasil. 3. Esportes por equipe - Sistemas defensivos. I. De Rose Junior, Dante, orient. II. Título CDD 22.ed. - 796.3230981 
Nome: ANDRADE, Diego Leonardo

Título: Análise histórica da evolução dos sistemas defensivos no Basquetebol Brasileiro Masculino Adulto

Dissertação apresentada à Escola de Artes Ciências e Humanidades da Universidade de São Paulo para a obtenção do título de Mestre em Ciências, pelo programa de Pós-Graduação em Ciência da Atividade Física.

Área de Concentração:

Ciências Biológicas e da Saúde

Aprovado em:

Banca Examinadora

Prof. Dr.

Julgamento:

Prof. Dr.

Julgamento:

Prof. Dr.

Julgamento:
Instituição:

Assinatura:

Instituição:

Assinatura:

Instituição:

Assinatura: 
À minha filha, Larah Silver. Que com um sorriso lindo, sempre me motivou a continuar estudando, me apoiando e sendo a pessoa mais compreensiva de todo o mundo, no auge dos seus 6 aos 9 anos de idade, período em que precisei dedicar meu tempo a ela e à pesquisa.

Filha, sem você, nada disso seria possível. 


\section{Agradecimentos}

À Escola de Artes, Ciências e Humanidades da Universidade de São Paulo, que me acolheu de braços abertos e ofereceu toda estrutura e aparatos necessários para o desenvolvimento de toda a pesquisa, além de realizar um sonho que nunca achei que fosse alcançar, o de poder estudar na USP.

A todos profissionais da EACH-USP, que influenciaram diretamente meu desenvolvimento como profissional e ser humano. Entrei uma pessoa e garanto à vocês que saio um ser humano muito melhor.

Ao Prof. Dr. Dante De Rose Jr. que aceitou humildemente a difícil tarefa de orientar e desenvolver toda pesquisa comigo. Para muitos, descrevi esse processo como o de pai e filho, pois ele me mostrou o caminho, mesmo estando com medo de decepcioná-lo.

A Jornalista Débora Prado, que prontamente me atendeu e trabalhou na revisão gramatical, muito obrigado por ser essa pessoa maravilhosa.

Ao meu núcleo familiar, que mesmo não tão instruído em nível escolar, entendeu minha necessidade de seguir estudando e buscando melhorias, profissional e academicamente. Aqui, deixo meus mais sinceros agradecimentos.

Aos amigos, que ajudaram muito no desenvolvimento do meu trabalho, como Tássia Hada e Sérgio Lagrotta, que ajudaram em diversos momentos, doando tempo e atenção para mim e à Íbis Moraes, que muitas vezes pareceu estar mais preocupada com o desenvolvimento do trabalho do que eu mesmo, meu carinho por vocês será eterno.

À Parveeshah Balakrishnan, que com contatos diários, ouviu minhas reclamações e murmúrios, me manteve alinhado com meus objetivos e com o desenvolvimento da pesquisa. 


\section{RESUMO}

ANDRADE, Diego Leonardo. Análise histórica da evolução dos sistemas defensivos no Basquetebol Brasileiro Masculino Adulto. 2019. $152 \mathrm{f}$. Dissertação (Mestrado em Ciências) - Programa de Pós-Graduação em Ciências da Atividade Física, Escola de Artes Ciências e Humanidades, Universidade de São Paulo, São Paulo, 2019. Versão Corrigida.

Existe um processo de evolução do esporte, uma busca pelo dinamismo que influenciou o jogo técnica e taticamente, acompanhando a estruturação da modalidade manuais de Basquete foram criados como um dos primeiros utilizados no Brasil pela Escola de Educação Física do Exército em 1971 até os dias atuais. Nessa perspectiva, o presente trabalho, através de um levantamento histórico da evolução do esporte, tem como objetivo identificar a evolução e o comportamento da defesa no Basquetebol Brasileiro Masculino Adulto, identificando quais são as ações defensivas coletivas dentro de um jogo formal de Basquetebol brasileiro masculino adulto; os fatores que levaram os sistemas defensivos a sofrerem alterações; como a defesa no Basquetebol se articula na forma como o esporte é jogado nos dias atuais. Criado pelo James Naismith com 5 normas para a prática do jogo, para os dias atuais com 8 regras divididas em 50 artigos, o basquetebol passou por um processo de evolução e diversas alterações na dinâmica do jogo aconteceram, por conta desse processo de evolução e alteração das regras, desde os primeiros relatos do sistema defensivo individual até os dias de hoje, que levou a uma classificação dos sistemas defensivos. Para organização pedagógica do trabalho, escolheu-se seguir a classificação dos sistemas defensivos apresentada por Paes, Montagner e Ferreira (2009) e para o cumprimento da analise proposta, foram entrevistados 14 profissionais, dentre eles, técnicos, ex-atletas, árbitros e especialistas. O estudo utilizou uma abordagem qualitativa de natureza aplicada no qual foram realizadas entrevistas individuais de profundidade, baseadas em um tópico guia seguindo a proposta metodologia da entrevista narrativa e para a análise dos dados, a Análise de Conteúdo de Bardin (2016). Ao todo, foram criadas 103 unidades de registro através da análise proposta, divididas nas fases do tópico guia da entrevista. O jogo conceito, atleticísmo e a pressão foram grupos focais de análise com maior incidência na categoria de características do jogo, além dos três grupos aparecerem em mais de uma categoria e terem outros grupos que de alguma forma, podem ser relacionados a eles, o jogo conceito e as nomenclaturas ganham destaque, sendo talvez a próxima fase do jogo, a próxima evolução, de um esporte cada vez mais atlético e com o espaço reduzido devido ao atleticísmo e as valências físicas dos atletas, sendo o atleticísmo um fator determinante para alterações no basquetebol como esporte e em seus sistemas de jogo. Seguindo os objetivos do trabalho, foi apresentada a interpretação para evolução dos sistemas defensivos, dentro dessa evolução, foi apresentada uma classificação com quatro grandes grupos de sistemas defensivos. Concluiu-se que o basquetebol evoluiu devido o atleticísmo dos jogadores, que levou ao maior contato físico, os sistemas se articulam através do jogo conceito, assim sendo, se faz necessária a atualização dos conteúdos dos grupos, porém, a classificação tradicional dos sistemas defensivos é considerada válida pelos entrevistados.

Palavras chave: Basquetebol. Evolução do esporte. Evolução histórica. Sistemas defensivos. Evolução do basquetebol. 


\begin{abstract}
ANDRADE, Diego Leonardo. Historical Evolution Analyses of Defensive Sistems

in Mens Brazilian Basketball.2019. 152 p. Dissertation (Master of Science) Physical Activity Science Program, School of Arts, Sciences and Humanities, University of São Paulo, São Paulo, 2019. Corrected version.
\end{abstract}

Since its creation in 1891 basketball has been evolving, internationalized and institutionalized, to the modality as it is practiced today. There is a process of evolution of the sport, a search for dynamism that influenced the game technically and tactically, accompanying the structuring of the game manuals of that was created similar to the one first used in Brazil by the Army's Physical Education School in 1971 until present day. In this perspective, the present work, through a historical survey of the basketball evolution, aims to identify the evolution and defensive behavior in the male Brazilian basketball, identifying which are the collective defensive actions within a basketball game; the factors that led the defensive systems to change; as the basketball defense is articulated the way the game is played in the present day. This research was conducted through interviews with former athletes, coaches, referees and experts of the sports. Created by James Naismith with 5 rules to play the game, for the present days with 8 rules divided in 50 articles, basketball has undergone a process of evolution and several changes in game dynamics appeared, due to this process and the changes of the rules, from the first reports of the individual defensive system to the present days, wihich led to a classification of defensive systems. For the pedagogical organization of this research, it was chosen to follow the defense methods presented by Paes, Montagner and Ferreira (2009) and for the fulfillment of the proposed analysis, 14 professionals were interviewed, among them, former athletes, coaches, referees and basketball specialists. The Study used a qualitative approach of applied nature, using the individual interview of depth, based on a topic guide following the proposed methodology of the narrative interview and for analysis of the data, Bardin's Contend Analyses (2016). Altogether, 103 recording units were created through the proposed analysis, divided into phases of the interview guide topic. The game concept, athleticism and pressure were focus groups of analysis with more incidence in the game characteristics category, besides these three groups appear in more categories and have other groups that of some form, can be related to them, the game concept and the terminologies are highlihjted, being perhaps the next phase of the game evolution, in an increasingly athletic and with lesser space on the court due to the athleticism and physical values of the athletes, being the athleticism a determinant factor for changes in the basketball. Following the objectives of the work, we presented the interpretation of the defensive systems evolution, a classification with four large groups of defensive systems. It was concluded that basketball evolved due to athleticism of the players, which led to greater physical contact, systems are articulated through the concept game, thus, it is necessary to update the contents of the groups, however, the classification of defensive systems still is valid.

Keywords: Basketball. Sport evolution. Historical evolution. Defensive systems. Basketball evolution. 


\section{LISTA DE FIGURAS}

Figura 01 - Diagrama da quadra de basquetebol inteira ............................. 28

Figura 02 - Diagrama da área restritiva .............................................. 29

Figura 03 - Diagrama área de pontuação ............................................ 30

Figura 04 - Anagramas conjunto de defesas pares ............................... 37

Figura 05 - Anagramas conjunto de defesas ímpares ................................ 38

Figura 06 - Anagramas sistema defensivo misto box-one ......................... 39

Figura 07 - Anagramas sistema defensivo misto diamond-one .................... 39

Figura 08 - Anagramas sistema defensivo misto triângulo-dois ................... 40

Figura 09 - Anagramas sistema defensivo misto três individual-dois em zona . 40

Figura 10 - Conjunto de anagramas sistema defensivo misto match-up ........... 41

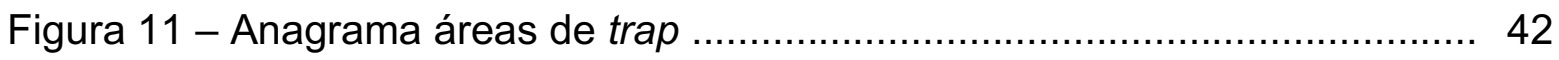

Figura 12 - Conjunto de anagramas sistema defensivo pressão zona 1:2:1:1 .. 43

Figura 13 - Fluxograma de desenvolvimento de análise ............................. 49

Figura 14 - Fluxograma de desenvolvimento de análise ............................ 50 


\section{LISTA DE QUADROS}

Quadro 01 - 05 Normas do Basquetebol em 1891 22

Quadro 02 - Linha do Tempo das Grandes Alterações das Regras do Basquetebol 23

Quadro 03 - Primeiros relatos de alterações dos Sistemas Defensivos 25

Quadro 04 - Alterações visuais/estruturais na Quadra 26

Quadro 05 - Tópico Guia - Estrutura da Entrevista Narrativa 46

Quadro 06 - Descrição dos Grupos Focais Formados/Unidades de Registro e Contexto 


\section{LISTA DE TABELAS}

Tabela 01 - Conjunto de Categorias - Tópico Inicial ...................................... 55

Tabela 02 - Conjunto de Categorias - Aspectos/Evolução Defensiva ................. 56

Tabela 03 - Conjunto de Categorias - Fundamentos Téc/Tát e Ataque x Defesa. 57

Tabela 04 - Conjunto de Categorias - Conhecimento do Jogo ......................... 58

Tabela 05 - Conjunto de Categorias - Essencial ........................................ 59

Tabela 06 - Conjunto de Categorias - Classificação dos Sistemas Defensivos .. 60

Tabela 07 - Conjunto de Categorias - Sugestão de Nova Classificação ............. 60

Tabela 08 - Conjunto de Categorias - Todas as Narrativas ............................... 62

Tabela 09 - Estatísticas de Todas as Temporadas do Novo Basquete Brasil ...... 63 


\section{LISTA DE ABREVIATURAS}

ATBB - Associação de Técnicos de Basquetebol

ACM - Associação Cristã de Moços

CBB - Confederação Brasileira de Basketball

FIBA - Federação Internacional de Basquetebol

LNB - Liga Nacional de Basquete

NBB - Novo Basquete Brasil

NBA - National Basketball Association 


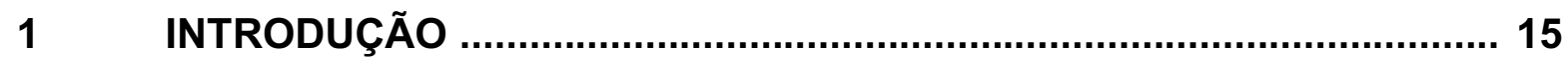

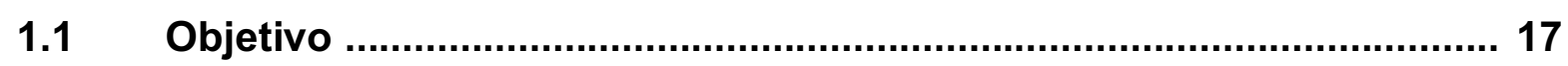

2 BASQUETEBOL - CARACTERIZAÇÃO DA MODALIDADE ................. 18

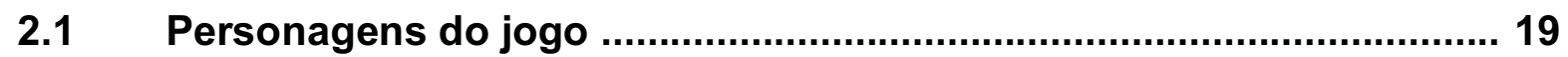

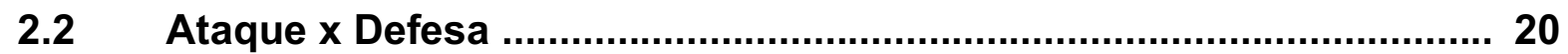

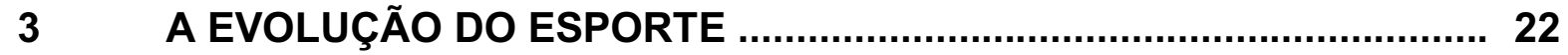

$4 \quad$ DEFESA NO BASQUETEBOL …................................................ 32

4.1 Posturas e deslocamentos defensivos ......................................... 42

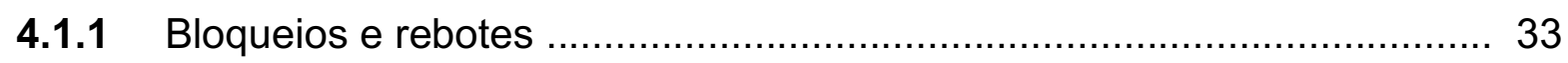

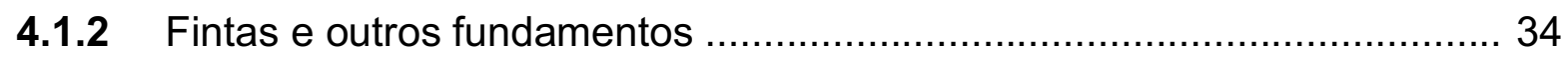

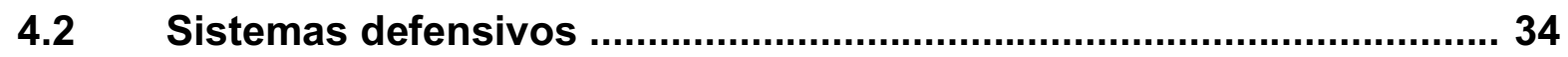

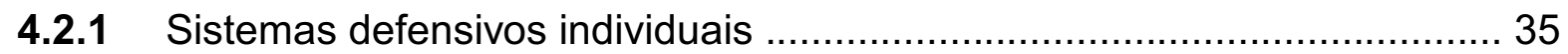

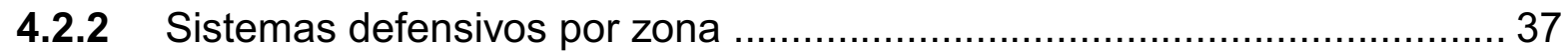

4.2.3 Sistemas defensivos mistos ou combinados .................................... 38

4.2.4 Sistemas defensivos pressão …………...................................... 41

5 PROCESSOS E PROCEDIMENTOS METODOLÓGICOS DE PESQUISA

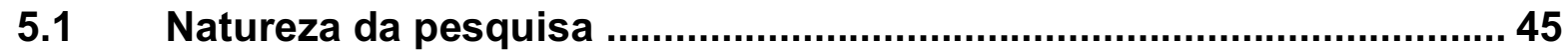

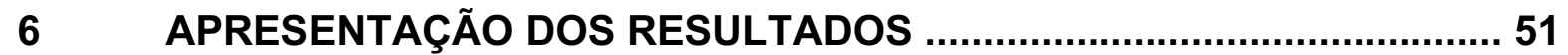

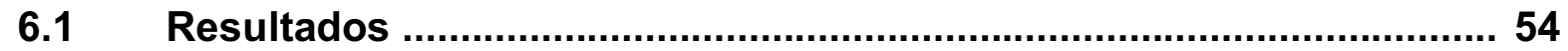

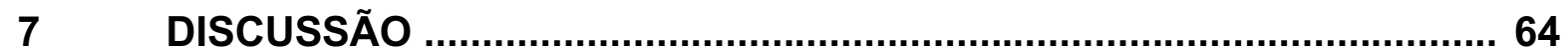

8 CONSIDERAÇÕES FINAIS E CONCLUSÃO ……..............................69

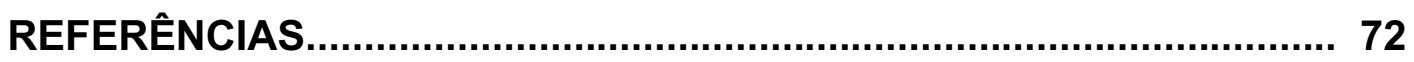

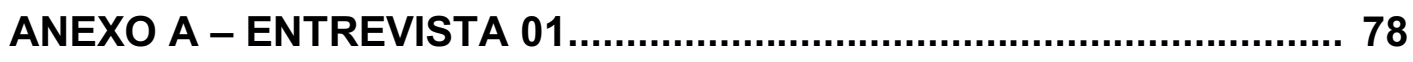

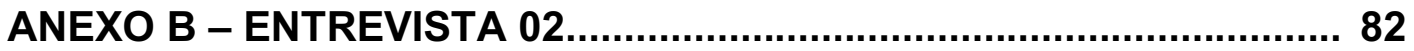

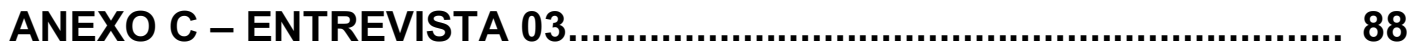

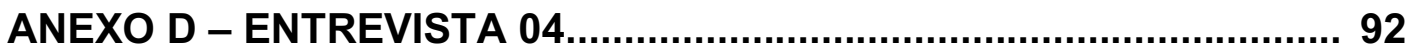

ANEXO E - ENTREVISTA 05 .......................................................... 98

ANEXO F - ENTREVISTA 06...................................................... 101

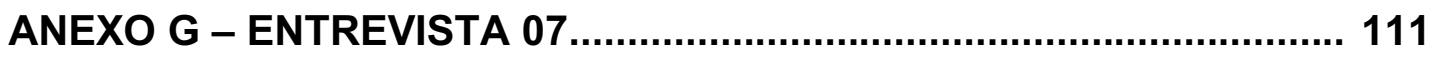

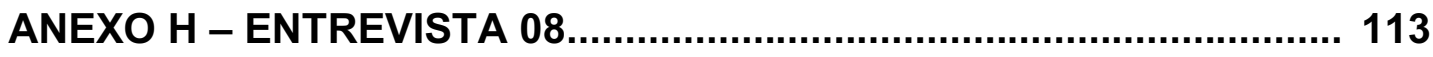

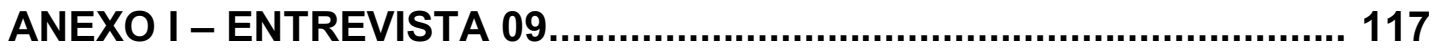




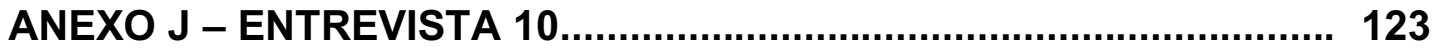

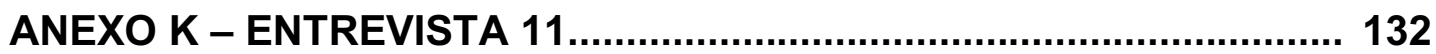

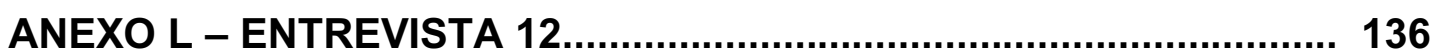

ANEXO M - ENTREVISTA 13........................................................ 140

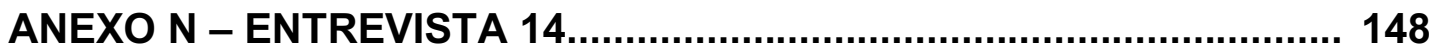




\section{INTRODUÇÃO}

Criado em 1891, o basquetebol surgiu como uma opção de prática de atividade física para os alunos do colégio internacional da Associação Cristã de Moços (ACM), em Springfield, Massachusetts nos Estados Unidos.

Luther Hasley Gullick, diretor do Springfield College, preocupado com a evasão dos alunos das práticas de atividade física, pediu ao professor James Naismith que arrumasse uma solução para esse problema. Uma das preocupações na criação dessa nova atividade foi a de apresentar um jogo não violento, visto que os possíveis praticantes iriam ser alunos atletas de Rugby, modalidade muito praticada naquela região, além de algo diferente do conhecido até então. Assim, foi criado o basquetebol. (CBB, 2016).

Existem divergências sobre como surgiu a ideia utilizada na concepção do jogo. Uma delas apontada por Oliveira (2012) é de que alguns professores estavam na sala conversando sobre assuntos diversos, entre eles a criação do basquetebol e enquanto rascunhavam as suas ideias, as não utilizadas viravam bolinhas de papel arremessadas no cesto de lixo, Naismith, observando a prática, teve a ideia inicial para a concepção do novo Jogo.

Por sua vez, Duarte (2013) aponta as ideias mais difundidas sobre a elaboração do que seria o basquetebol. Segundo o autor, o jogo foi baseado em duas brincadeiras que eram praticadas na época.

Uma delas era simplesmente $o$ ato de jogar pedras no lago, desde que elas traçassem uma trajetória parabólica, já a outra brincadeira, chamada de Patos no Rochedo, consistia em um amontoado de pedras sobre uma rocha e os participantes deveriam derrubar esse amontoado jogando outra pedra sobre.

O basquetebol foi evoluindo e se institucionalizando na modalidade que é praticada hoje por mais de 450 milhões de pessoas no mundo (FIBA, 2016), mas toda essa evolução do esporte pode ter influenciado a forma de se jogar o jogo.

Historicamente, desde a criação das 13 regras iniciais do basquetebol em 1891 (ÁREA RESTRITIVA, 2018), até o livro de regras utilizadas hoje em dia e que tiveram a última atualização em 2017 (CBB, 2018), o basquetebol passou por uma grande evolução, com o objetivo de deixar o esporte cada vez mais dinâmico. 
Desde uma simples mudança de regra, como o cortar o fundo dos cestos de pêssego para acelerar a reposição de bola, pois nos primeiros jogos, depois de uma cesta, os jogadores precisavam pegar uma escada para poder subir e tirar a bola e recomeçar a partida, com reposições de bola laterais e no fundo de quadra. Todas as mudanças tinham como um objetivo primário deixar o jogo mais dinâmico e emocionante (COOPER; SIEDENTOP, 1975).

Toda evolução do esporte influenciou também o jogo tática e tecnicamente, alterações na quantidade de jogadores, inclusão da linha de três pontos e as alterações do formato da área restritiva, tiveram influência direta em como a ação do jogo acontecia.

Acompanhando a estruturação e evolução do basquetebol, como modalidade esportiva, com o passar dos anos, passaram a ser desenvolvidos guias com os fundamentos técnicos, que chegaram ao Brasil como o manual de basquetebol utilizado pela Escola de Educação Física do Exército em 1971, até os primeiros livros didáticos de basquetebol, onde os fundamentos técnicos e estratégico-táticos passaram a ser organizados e sistematizados, como a obra de Duarte (2013), uma das obras mais recentes publicadas no Brasil que apresenta uma classificação dos fundamentos técnicos e táticos do jogo.

Assim sendo, os treinos de basquetebol em clubes e escolas passaram a tomar um corpo e o esporte passou a ser desenvolvido. Porém, uma questão pertinente pode ser levantada. A literatura da modalidade acompanhou a evolução do jogo ou até mesmo a classificação clássica dos sistemas defensivos no basquetebol condiz com a forma com que o jogo é jogado atualmente?

Refletindo sobre o histórico da modalidade e a evolução do esporte, chegase aos questionamentos levantados pelo presente trabalho que tem como seu objeto de pesquisa a Defesa no Basquetebol Brasileiro Adulto Masculino de Alto Rendimento, como os fundamentos defensivos se organizam no basquetebol? 


\subsection{Objetivos}

Nessa perspectiva, o presente trabalho, através de um levantamento histórico da evolução do esporte, tem como objetivo identificar a evolução e o comportamento da defesa no Basquetebol Brasileiro Masculino Adulto, levando em consideração equipes de alto rendimento. Desta forma, os objetivos específicos desta pesquisa são:

* Fazer levantamento histórico da evolução da defesa no basquetebol, para assim, identificar quais são as ações defensivas coletivas dentro de um jogo formal de Basquetebol Brasileiro Masculino Adulto;

Identificar fatores que levaram os sistemas defensivos a sofrerem alterações, podendo ser elas simples mudanças de sistema empregado pela equipe, ou mudanças em posturas e organização estratégico-tática.

- Identificar como a defesa no basquetebol se articula na forma como o esporte é jogado atualmente, através de entrevistas com atletas, técnicos e especialistas da modalidade. 


\section{BASQUETEBOL - CARACTERIZAÇÃO DA MODALIDADE}

Jogos coletivos são grupos de modalidades que têm ações resultantes da interação constante entre jogadores, cooperando entre si e em oposição a outra equipe.

Seguindo a classificação apresentada por Reverdito e Scaglia (2009), podese incluir a esse grupo de modalidades, os jogos coletivos de invasão, a qual se inclui o basquetebol, caracterizados pela liberdade de atuação das equipes dentro do campo de jogo, podendo realizar ações do jogo tanto em seu campo de defesa como no do adversário.

Segundo a análise da estrutura funcional dos jogos coletivos, tanto de equipe atacante quanto defensora, devem levar em consideração alguns pontos, que são a conservação da bola e a intervenção sobre ela, o confronto direto entre as equipes no espaço de jogo e a comunicação entre membros da mesma equipe e contra comunicação feita pelos adversários, independentemente de ser a equipe atacante ou defensora (REVERDITO; SCAGLIA, 2009).

Ambientando o basquetebol como uma modalidade esportiva coletiva, existem diversas classificações, conforme apontam De Rose Jr. e Silva (2011). Podese classificar o basquetebol como esporte coletivo com bola, de conhecimento do oponente e modalidade esportiva aberta.

Em uma caracterização feita por Ferreira e De Rose Jr (2010), o basquetebol é uma modalidade esportiva de oposição e cooperação, entre adversários e companheiros de equipe, envolvendo ações simultâneas entre essas duas equipes, que ocupam espaço comum, proporcionando contato direto entre participantes.

Sendo que habilidades específicas da modalidade ou fundamentos técnicos são executados em ambiente aberto, com exceção do lance livre, - o único momento do jogo onde uma um gesto técnico (o arremesso) - é executado em um ambiente fechado.

Segundo a ambientação sistêmica do esporte apresentada por Tani e Corrêa (2011), o basquetebol pode ser considerado um esporte praticado em sistema essencialmente aberto, pois, elementos do jogo utilizam e trocam energia e informação dentro do ecossistema do esporte, permitindo alterações de seus elementos. 
Para a excelência da prática esportiva do basquetebol, se faz necessário aprimoramento das capacidades relacionadas ao jogo. Para isso, deve-se levar em consideração dentro do planejamento de uma equipe de basquetebol, o treinamento das capacidades físicas, coordenativas e cognitivas.

Com o passar do tempo, a preparação física relacionada ao basquetebol tem evoluído. Ao se pensar nas capacidades físicas do esporte, Lamas (2006) afirma que, espera-se que gestos técnicos sejam realizados de forma continuada e com menor queda de desempenho possível ao longo do jogo. Neste mesmo contexto, em ensaio apresentado por Isnidarsi e Oliveira (2013), os autores apontam a potência muscular como capacidade mais específica do basquetebol, lembrando que a potência deriva diretamente da força muscular.

Dada a complexidade dos fundamentos do basquetebol, as capacidades coordenativas relacionadas ao esporte devem ser levadas em consideração. Já que a função da coordenação é convergir diversas funções motoras e psíquicas. Para o aprimoramento dos padrões motores capacidades coordenativas, devem ser estimuladas e um planejamento a longo prazo deve ser elaborado com tais preocupações, (OLIVEIRA; PAES, 2004; CARVALHO; ASSUNÇÃO; PINHEIRO, 2009).

As capacidades cognitivas segundo Bianco (2011), são relacionadas diretamente ao alcance do bom rendimento no esporte. A autora aponta que os processos cognitivos são responsáveis pelo reconhecimento elaboração e memorização das informações, sendo então relacionados à percepção, antecipação, tomada de decisão, atenção, pensamento, imaginação, velocidade de reação e até mesmo ao sentido de tempo e espaço. Abernethy, Wann e Parks (2000), apontam que a percepção e tomada de decisão são determinantes para o sucesso no alto nível.

\subsection{Personagens do jogo}

Para o presente trabalho, seguiremos as regras e normas da Federação Internacional de Basquetebol (FIBA), formada por 12 atletas, conforme aponta Drewett (2009), e posições tradicionais da modalidade são o Armador, Ala e o Pivô.

O armador, passou a ser chamado de jogador na posição 1, assim como o ala-armador ou escolta, passou a ser chamado de jogador na posição 2. Os 
armadores são os atletas que fazem a maior quantidade de passes e os que mais driblam durante o jogo de basquetebol, já que são jogadores responsáveis em organizar o ataque e levam a bola na transição defesa-ataque (OKAZAKI et al, 2004).

O ala, passou a ser chamado de jogador na posição 3, assim como o ala-pivô, ou pivố-móvel passou a ser chamado de jogador na posição 4. Os alas são os jogadores que mais arremessam durante as partidas, com um número maior de arremessos de 3 pontos, jumps e bandejas, consequentemente os maiores pontuadores (OKAZAKI et al, 2004).

Em uma análise das temporadas 2009/10, 2010/11 e 2011/12 do Novo Basquete Brasil, feita por Meneses, Gois Jr e Almeida (2016), foi constatada diminuição dos arremessos de três pontos e aumento dos arremessos de média distância, deixando o jogo de basquetebol um jogo mais físico.

Por sua vez, o pivô, ou pivô-fixo, é o jogador na posição 5. Possui representatividade muito grande dentro da área restritiva, com uma variedade muito grande de arremessos, é o jogador com o maior número de rebotes e bloqueios, além de ser o jogador que mais arremessa lances livres e faz arremessos de dois pontos (OKAZAKI et al, 2004). Porém, Meneses, Gois Jr e Almeida (2016), apontam que a função do pivô se resumiu a pegar rebotes, com pouca influência no sistema ofensivo.

\subsection{Ataque x Defesa}

No basquetebol, como aponta Oliveira (2012), o objetivo do jogo é pontuar e impedir que o adversário pontue, configurando assim, a premissa já apresentada neste trabalho de Esporte de Interação e Oposição, onde duas equipes disputam o controle sobre a posse de bola, além de compartilharem mesmo espaço para a prática do jogo (DE ROSE JR; SILVA, 2011; FERREIRA; DE ROSE JR, 2010; REVERDITO; SCAGLIA, 2009).

Nessa perspectiva, existe o ataque e a defesa, caracterizados pela posse ou não da bola, respectivamente. (FERREIRA; DE ROSE JR, 2010; PAES; MONTAGNER; FERREIRA, 2009).

Alguns autores associam a defesa com a vitória no basquetebol, como Brandão, Janeira e Sampaio (2002), que relacionam a eficácia defensiva tanto em 
vitórias em jogos, onde a diferença de pontos é superior a 24 pontos, como em partidas equilibradas, que são jogos onde a diferença do placar é inferior a 10 pontos.

De Rose Jr. (2002) aponta que equipes mandantes vitoriosas são mais efetivas nos rebotes, por consequência, aumentam o volume de jogo dando mais chances de novos ataques, ou como detalha Gonzalez, Balbinotti e Saldanha (2009), que o rebote defensivo, pode gerar contra-ataques e o rebote ofensivo, possibilitará segundas chances de arremesso, com grande possibilidade de serem próximas a cesta.

Porém, o esporte nem sempre foi jogado da forma como é jogado atualmente, apesar de manter suas principais características como a altura da cesta e o tamanho e cor da bola, o esporte passa por uma evolução constante. 


\section{A EVOLUÇÃO DO ESPORTE}

O basquetebol como jogo até se transformar no fenômeno esportivo mundialmente conhecido, passou por diversas transformações. Apesar de como já apontado, manter as suas principais características o esporte evoluiu com o tempo, grande exemplo disso são as regras do jogo.

Inicialmente, o novo jogo apresentado por James Naismith, foi baseado em cinco normas (Quadro 1), que foram a base para as treze regras iniciais, apresentadas em duas folhas fixadas em um quadro de avisos da escola. Esse era o anúncio do que viraria um fenômeno mundial, o basquetebol (PAES; MONTAGNER; FERREIRA, 2009).

O jogo não parou por aí, para isso, foi necessária em 1894, a criação de um comitê de regras para apurar os acontecimentos do esporte e assim, discutir alterações nas regras do jogo e em sua estrutura física, como aponta um texto exposto na página Estudo Geral, da Universidade de Coimbra (2018). Já no primeiro ano de atividade do comitê a pontuação do jogo, foi revista e também foi introduzido o Lance Livre e a Tabela Foi criada (Quadro 02).

\section{Quadro 01 - 5 Normas do basquetebol}

\begin{tabular}{|r|l|}
\hline \multicolumn{1}{|c|}{ Regra } & \\
\hline $\mathbf{1}$ & O jogo é jogado com uma bola redonda e com as mãos. \\
$\mathbf{2}$ & Um jogador não pode correr com a bola. \\
$\mathbf{3}$ & Qualquer jogador pode atuar em qualquer posição da quadra. \\
$\mathbf{4}$ & Não haverá contato físico entre os jogadores. \\
\hline $\mathbf{5}$ & O gol (cesta) deverá ser colocado horizontalmente acima da quadra. \\
\hline
\end{tabular}

Fonte: Paes, Montagner e Ferreira (2009)

Atualmente, o basquetebol organizado pela Federação Internacional de Basquetebol (FIBA), criada em 1932, impacto da internacionalização do esporte, a última versão do livro de regras tem 8 regras divididas em 50 artigos e 87 páginas (FIBA, 2018), as regras do esporte são revisadas de quatro em quatro anos dentro do calendário olímpico.

De maneira geral, as regras são organizadas para se manter uma fluidez e organização do jogo, para que dessa forma, as regras acompanhem a evolução natural do esporte. Uma das primeiras alterações, por exemplo, foi a primeira definição 
do número de jogadores, por mais que ainda não seja exato, em 1897, o número de jogadores foi fixado entre 5 e 9, sendo obrigatório somente 5 jogadores em quadra em partidas oficiais e competições (UNIVERSIDADE DE COIMBRA, 2018; FERREIRA; DE ROSE JR, 2010).

Em 1942, o número de jogadores no banco de reservas foi fixado em 5 , como conta no livro de regras publicado no Brasil. No mesmo ano, porém, o número de substituições era limitado, cada jogador podia entrar em quadra apenas duas vezes, regra que foi abolida dois anos depois (PAES; MONTAGNER; FERREIRA, 2009; CBB, 1942).

A forma como a reposição de bola acontece no jogo também foi alvo de discussão por muito tempo. Em 1914, foi definido que a reposição de bola seria feita sempre nas laterais da quadra, em 1932, após qualquer cesta convertida, uma nova disputa de bola ao alto era realizada (PAES; MONTAGNER; FERREIRA, 2009).

Em 1936, o basquetebol foi incluso no Programa Olímpico dos Jogos de Berlim e um congresso foi realizado para discutir o esporte, nesse congresso, grandes mudanças foram realizadas e talvez a maior delas - naquela época - pensando na fluidez do jogo, foi retirar o bola ao alto após cesta, sendo instituído o fundo bola para a reposição de bola em jogo, (ZOLT, 2018) conforme consta na quadro 02.

\section{Quadro 02 - Linha do tempo das grandes alterações das regras do basquetebol}

\begin{tabular}{|c|c|}
\hline Ano & Acontecimento/Mudança \\
\hline 1894 & Criação do Lance-Livre. \\
\hline 1896 & $\begin{array}{l}\text { Definida a pontuação do jogo (Arremesso de Lance Livre = } 1 \text { Ponto, Arremesso de } \\
\text { Quadra } 2 \text { Pontos). }\end{array}$ \\
\hline 1896 & Definido o número de jogadores, entre 5 e 9. \\
\hline 1910 & Jogador é desqualificado com 4 faltas. \\
\hline 1914 & Reposição de bola feita na lateral. \\
\hline 1932 & $\begin{array}{l}\text { Criação da Regra de } 3 \text { segundos e criação da regra dos } 10 \text { segundos para transição; } \\
\text { quadra de defesa, para quadra de ataque. }\end{array}$ \\
\hline 1936 & Reposição de bola após cesta feita na linha de fundo. \\
\hline 1942 & $\begin{array}{l}\text { Definido que uma equipe pode ter } 5 \text { jogadores em quadra e } 5 \text { jogadores no banco } \\
\text { de reservas. }\end{array}$ \\
\hline
\end{tabular}




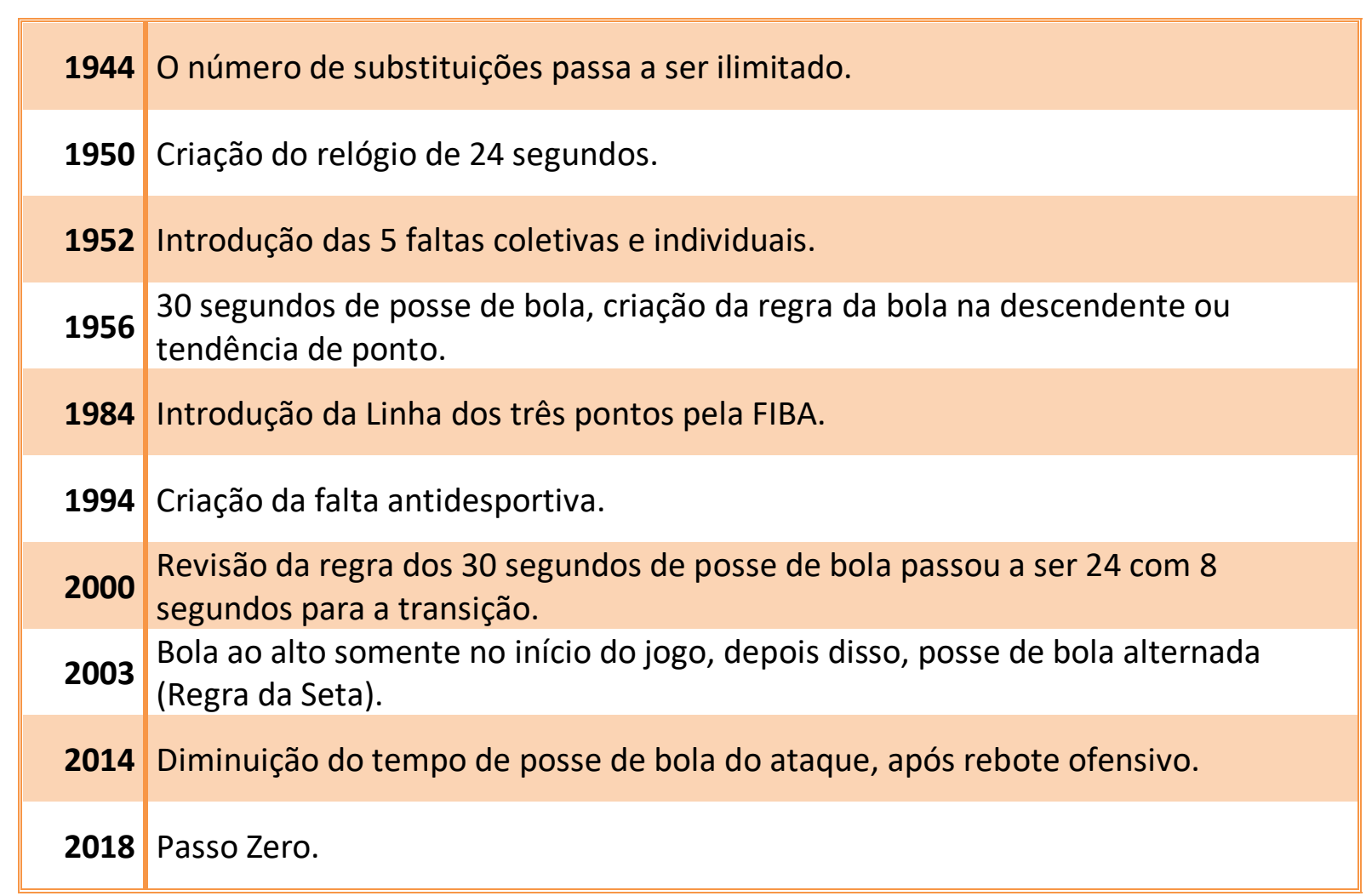

Fonte: Diego Leonardo de Andrade, 2019

Quando se pensa nos sistemas defensivos, por mais que não existissem as mesmas nomenclaturas apresentadas por diversos autores atualmente, partidas de basquetebol inicialmente com predomínio da defesa sobre o ataque, tinham em suas equipes sistemas defensivos individuais simples, segundo o Harvey County Historical Museum (2018), isso se seguiu até 1914 com a primeira equipe a utilizar um sistema defensivo zona, introduzido por Frank Lindley (Quadro 3).

Em um conceito simples, Coach Lindley deixou de marcar o homem e dizia para marcarem o espaço, essa era a definição utilizada por Lindley, que é a mesma utilizada até hoje, mas sistematizada em linhas defensivas, advinda dos sistemas defensivos zona de Lindley, a equipe aplicou também jogos de transição e contraataques e com isso, conquistou um recorde de 594 vitórias e 118 derrotas e 10 títulos estaduais sob o comando de Lindley (COMPLEX, 2018; Harvey County Voices, 2018). 
Quadro 03 - Primeiros relato de alterações dos sistemas defensivos

\begin{tabular}{|r|l||}
\hline Ano & Tipos de Alterações nos Sistemas de Jogo \\
\hline 1891 & Sistemas individuais simples - James Naismith; \\
\hline 1914 & Sistemas defensivos por zona - Coach Lindley; \\
\hline 1936 & Jogos de transição depois do fundo bola; \\
\hline 1939 & Primeiros relatos de contra-ataque; \\
1950 & Sistemas defensivos pressão - Coach Johnson. \\
\hline
\end{tabular}

Fonte: Diego Leonardo de Andrade, 2019

A modalidade continua a crescer mundialmente e uma movimentação que atualmente acontece, a fim de unificar alguns termos do basquetebol ou até mesmo regras da FIBA com as da NBA, já era previsto desde a criação da FIBA e as primeiras regras internacionais da modalidade. A partir de 1932, regras passaram a ser revistas a cada 4 anos, para coincidir com os ciclos olímpicos (PAES; MONTAGNER; FERREIRA, 2009).

Ainda em 1932, o que pode ser a primeira grande mudança no basquetebol, foi a criação da regra dos três segundos, onde o jogador atacante sem posse de bola não pode ficar mais que três segundos dentro da área restritiva, influenciando assim, diretamente as dinâmicas ofensivas daquela época (DE ROSE JR., 2018; PAES; MONTAGNER; FERREIRA, 2009).

A evolução dos sistemas defensivos por zona, propostos por Lindley em 1914 (tabela 03), assim como os jogos de transição e contra-ataque, seguem se popularizando e em 1939, relatos de jogos de contra-ataque tomam o mundo, transições com muitos passes e corta-luz e o jogo não parou de evoluir estrategicamente (GUIDE TO COACHING BASKETBALL, 2018).

O ano de 1950 para a NBA e em 1954 para a FIBA, foram anos de grandes mudanças no basquetebol. Com a criação do relógio de 24 segundos, as equipes tinham tempo para concluir ações ofensivas, que colocou naturalmente pressão sobre o ataque. No mesmo período, mais um passo na evolução dos sistemas defensivos. A criação de sistemas defensivos pressão, criado por Gene Johnson, técnico da primeira seleção dos Estados Unidos, a ganhar a medalha de ouro Olímpica, nos Jogos de Berlim em 1936 (DUARTE, 2018; JONES, 2017).

Diversas alterações nas regras do jogo foram acontecendo no decorrer dos anos até a próxima grande mudança, a criação da linha dos três pontos em 1979 na 
NBA e sendo absorvida pela a FIBA em 1984, a linha de três pontos ficava a uma distância de $6,25 \mathrm{~m}$ da cesta as dimensões da quadra também mudaram de 26x14 para 28x15 (CBB, 1984).

O basquetebol chegou a um ponto onde regras passaram a ser alteradas por conta da disparidade de alguns atletas, após a regra dos três segundos, o formato da área restritiva também sofreu alterações: primeiro, o diâmetro foi aumentando até o formato que passou por duas alterações, a primeira em 1952 e depois em 2010.

Em 2010, ocorreram as últimas grandes mudanças, nas marcações ou estruturas do jogo, com o aumento da distância da linha dos três pontos, que passou de 6,25m para 6,75 (tabela 4), a inclusão do semicírculo de não carga e como já citado, a padronização internacional do formato da área restritiva, que deixou de ser um losango e passou a ser um retângulo (FIBA, 2010)

A quadro 04 apresenta a linha do tempo das alterações e atualizações visuais feitas na quadra de basquetebol.

\section{Quadro 04 - Alterações visuais/estruturais na quadra}

\begin{tabular}{|r|l|}
\hline Ano & Alterações \\
\hline 1891 & Foram introduzidas as primeiras tabelas. \\
\hline 1910 & Aprovada a Tabela de Vidro. \\
\hline 1930 & Suporte da Tabela ainda ficava dentro da quadra e a área restritiva era estreita. \\
\hline 1952 & Área restritiva ampliada. \\
\hline 1956 & Área restritiva tem o seu formato alterado para um trapézio. \\
\hline 1979 & A NBA cria a linha dos três pontos, em 1984 a FIBA também introduz a regra. \\
\hline 1979 & $\begin{array}{l}\text { Área restritiva igual da NBA, introdução do Semicírculo de Não Carga e expansão da } \\
\text { linha de três pontos. }\end{array}$ \\
\hline
\end{tabular}

Fonte: Diego Leonardo de Andrade, 2019

A diagramação da quadra até 2018, não sofreu novas alterações, seguindo da mesma forma desde 2010 e 2014, conforme figura 01.

Dessa forma, partidas oficiais de basquetebol são disputadas em quadras com 28 metros de cumprimento e 15 metros de largura (Figura 01), dividida ao meio pela linha central, todas as linhas da quadra devem ter 5 centímetros de largura (FIBA, 2018). 
Na região próxima as cestas, estão situadas as áreas restritivas, área em formato é o de retângulo, esses espaços têm 5,8 de comprimento, por 4,9 de largura (Figura 02), dois semicírculos, um interno e outro na extremidade da área restritiva. 
Figura 01 - Diagrama da quadra de basquetebol inteira

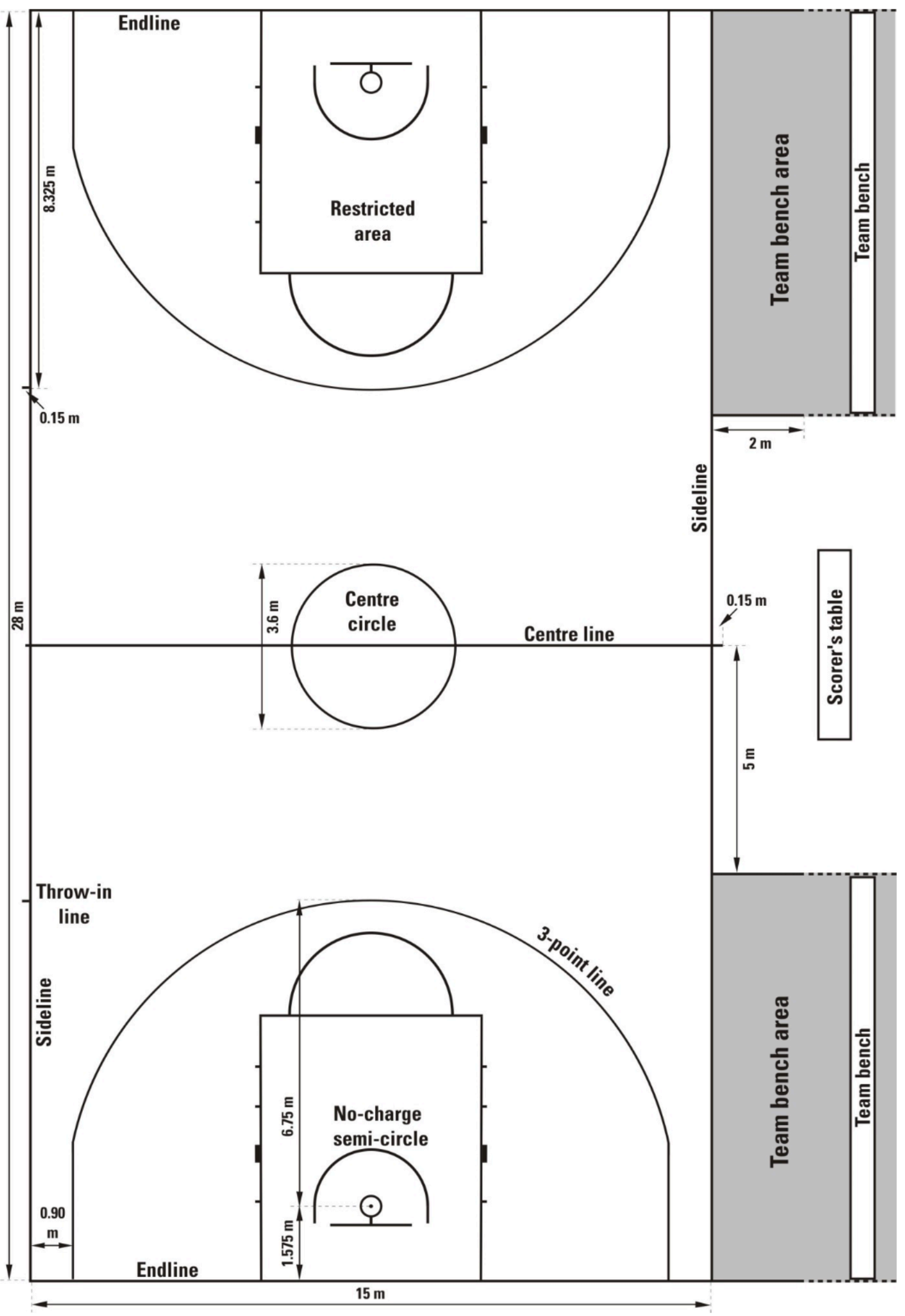

Fonte: Federação Internacional de Basketball (2018) 
O Interno é o semicírculo de não carga, localizado abaixo da cesta. Serve de marcação da área, onde o choque entre dois jogadores não é caracterizado falta de ataque, desde que o defensor esteja parado dentro do semicírculo antes do contato com o atacante, já o externo, é um espaço reservado para a cobrança de lanceslivres, (figura 02).

Figura 02 - Diagrama da área restritiva

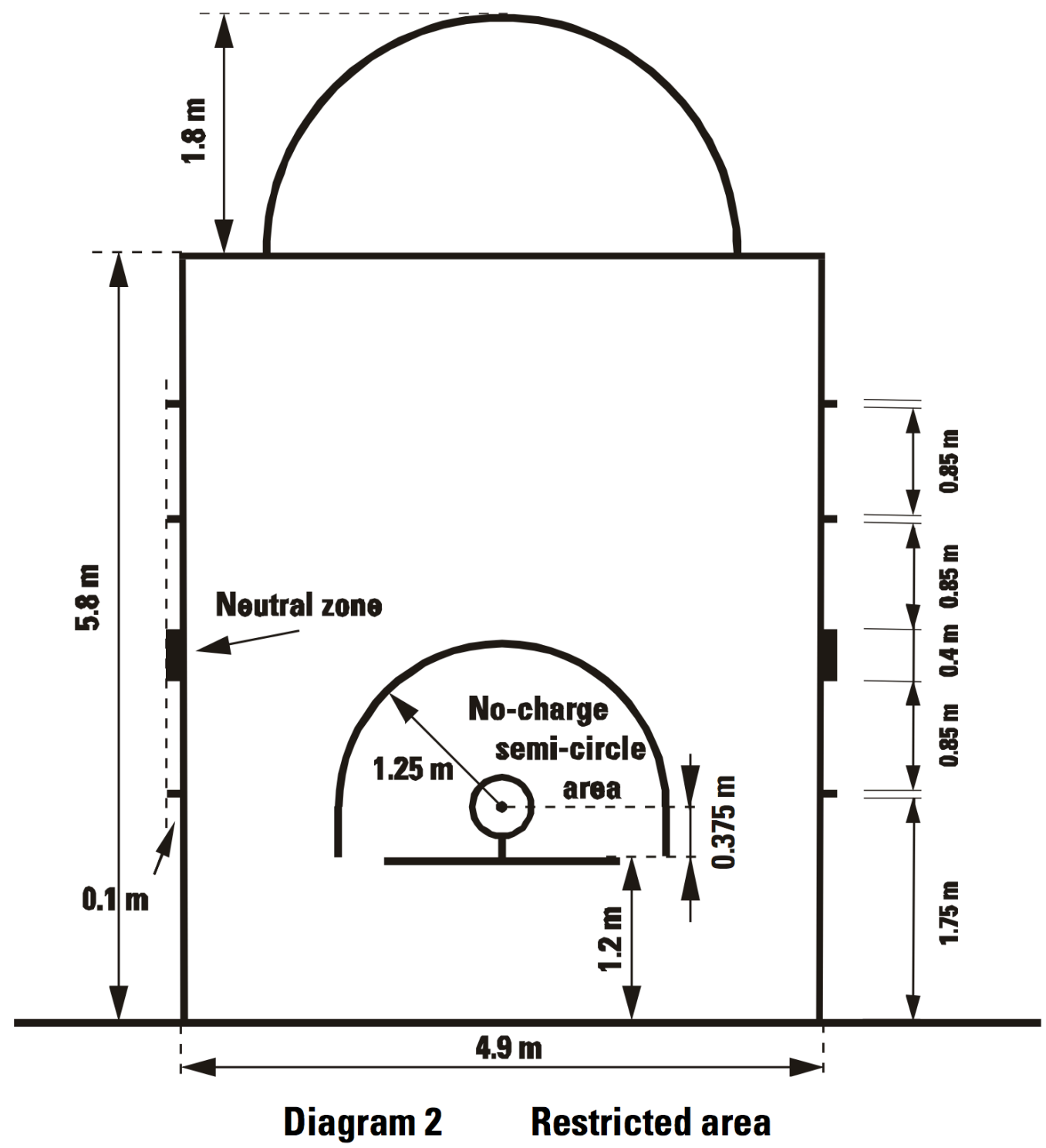

Fonte: Federação Internacional de Basketball (2018)

A última área demarcada dentro da quadra de basquetebol é a linha de três pontos, demarcadas a uma distância de 6,75 metros (figura 01), influenciando diretamente a configuração dos sistemas defensivos, (FIBA, 2016). 
A Figura 03 apresenta diagrama das áreas de pontuação na quadra de basquetebol, mas é importante ressaltar que os lances livres são arremessos que valem um ponto e o arremesso é feito do topo da área restritiva, como abordado anteriormente. Os lances livres são únicos momentos do jogo onde o arremesso é feito sem o contato direto com adversários.

Figura 03 - Diagrama área de pontuação

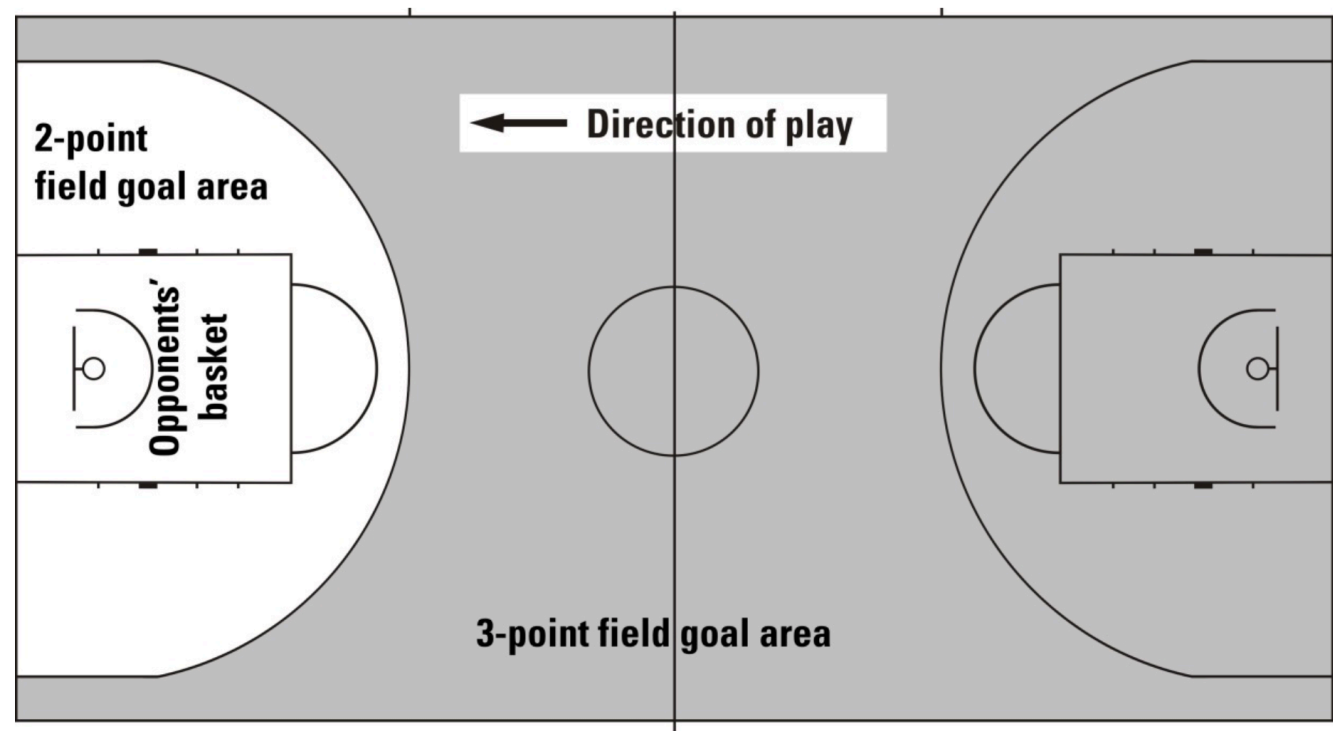

Diagram 3 2-point/3-point field goal area

Fonte: Federação Internacional de Basketball (2018)

Mas, o basquetebol segue evoluindo e mudando. Em 2014, mudanças no tempo de posse de bola também aconteceram e em 2018, a padronização internacional do passo zero. Uma mudança ainda sem precedentes dentro do jogo, mas que irá gerar uma diminuição na quantidade de violações com "andadas" por conta da padronização entre FIBA e NBA (FIBA, 2018; FIBA, 2014).

Contraponto as tabelas expostas, é possível identificar relações entre mudanças de regras e sistemas defensivos, partindo do princípio que mudanças de regras servem para deixar o jogo mais fluído, algumas delas aconteceram para evitar supremacia de jogadores ou de sistemas defensivos, porém, os sistemas continuam se articulando dentro do jogo.

Um exemplo dessas alterações são mudanças no formato da área restritiva, criação e aumento da distância da Linha dos Três Pontos, que podem influenciar diretamente a configuração dos sistemas defensivos, por resultarem em alterações 
diretas nos sistemas ofensivos, ou como a criação do relógio de 24 segundo em 1950 (Tabela 02) pode ter ligação com os sistemas defensivos pressão (Tabela 03), ou pelo menos, passaram a serem mais efetivos, já que além da pressão exercida pela defesa, existe pressão do tempo de posse de bola (KURTUS, 2018).

Um ponto é importante na organização de equipes e filosofias de trabalho, são as regras e organização da modalidade, conforme aponta Duarte (2016), pois de acordo com as regras, regulamentos e alguns fatores organizacionais do basquetebol influenciam diretamente fundamentos técnicos e organização de seus sistemas de jogo. 


\section{DEFESA NO BASQUETEBOL}

Esportes são caracterizados por fundamentos técnicos e o basquetebol não seria uma modalidade diferente. Segundo Paes, Montagner e Ferreira (2009), fundamentos são partes constitutivas do jogo, sendo eles ações técnicas realizadas pelos atletas durante o jogo, sendo sistematizadas em fundamentos ofensivos e defensivos.

Fundamentos defensivos ou princípios defensivos no basquetebol são ações que não permitem jogadores atacantes se moverem de forma livre, evitando que jogadores se posicionem, driblem, efetuem passes e recebam a bola, arremessem ou recuperem a bola em caso de rebote (FERREIRA; DE ROSE JR., 2010).

Paes, Montagner e Ferreira $(2009, p, 52)$ definem princípios defensivos da seguinte forma:

Baseiam-se na busca da recuperação da posse da bola; na tentativa de dificultar ou impedir a progressão do adversário à cesta; na constante busca de dificultar a organização do ataque adversário, visando a proteção da cesta (objetivando não sofrer pontos).

Essas ações defensivas serão apresentadas em suas definições a seguir.

\subsection{Posturas e deslocamentos defensivos}

Posturas defensivas ou posições defensivas são ações técnicas que têm como objetivo dificultar que o atacante efetue suas ações ofensivas de forma confortável, a postura defensiva deve permitir que o defensor consiga de forma ágil: deslocar-se e antecipar movimentações ofensivas, dificultar o drible, passe ou arremesso, interceptar o passe, bloquear arremesso e posicionar-se para um rebote (FERREIRA; DE ROSE JR., 2010).

A posição básica de defesa segundo Ferreira e De Rose Jr (2010) é quando o defensor está em afastamento lateral de membros inferiores, com os joelhos levemente flexionados, podendo ainda ter um dos membros inferiores postados ligeiramente à frente, o tronco deve estar ligeiramente inclinado e membros superiores podem estar em posições diferentes dependendo da situação do atacante.

Paes, Montagner e Ferreira (2009), apontam que para uma melhor proteção da cesta, defensores devem estar sempre entre o atacante e a cesta, sendo que o 
posicionamento em quadra deve sempre levar em consideração a bola, jogador ou jogadores adversários e cesta.

Quando o defensor está marcando um atacante que está driblando, este deve se mover acompanhando o atacante, bloqueando o caminho, ou seja, impedindo a progressão do atacante. Nesse caso, membros superiores do defensor estão posicionados abaixo da linha dos ombros procurando evitar passes, dribles e fintas com a bola (DREWETT, 2009).

Drewett (2009) ainda afirma que ao marcar um atacante sem a posse de bola, além de evitar o posicionamento do adversário em locais onde ele possa impor mais perigo, o defensor deve estar atento a possíveis passes, posicionando-se ao lado do adversário com o objetivo de evitar o recebimento da bola.

O autor também aponta que ao marcar um adversário em posição de arremesso, o defensor deve pressionar esse atacante, elevando os braços acima da linha dos ombros, utilizando braços e mãos para bloquear tentativas de arremesso ou até mesmo de passes.

Quanto ao deslocamento, os jogadores podem se movimentar lateralmente, para a frente e para trás, sempre atentos ao jogador adversário, deslocamentos laterais são feitos em deslizamentos, sem que os pés cruzem, em alguns momentos os movimentos são semelhantes aos da esgrima (FERREIRA; DE ROSE JR., 2010; DREWETT, 2009).

\subsubsection{Bloqueios e rebotes}

Existem dois fundamentos defensivos que estão muito presentes em jogos de basquetebol, são eles: bloqueios e rebotes.

Os bloqueios no basquetebol, também conhecidos como tocos, são ações técnicas que visam impedir o arremesso do adversário, interrompendo-o quando a bola ainda está na mão do adversário ou quando este já concluiu o arremesso. Porém, a bola só pode ser interceptada quando ainda não atingiu o ponto máximo da sua parábola, ou seja, o bloqueio só é válido quando a bola está em fase ascendente, caso contrário, os pontos são válidos, como previsto na regra da FIBA (GUERRA, 2001).

Quanto aos rebotes, podem ser ofensivos e defensivos, a diferença das ações é a origem do arremesso, quando um arremesso feito por qualquer atacante não é 
convertido e a bola é recuperada no rebote pela mesma equipe, é um rebote ofensivo, quando recuperada pela equipe adversária, é um rebote defensivo (FERREIRA; DE ROSE JR., 2010; PAES; MONTAGNER; FERREIRA, 2009).

A ação do rebote se inicia logo após o arremesso e segundo Ferreira e De Rose Jr. (2010), o rebote é dividido em 6 fases: acompanhamento visual da trajetória da bola, posicionamento, bloqueio do adversário, salto, tomada da bola e queda.

Em estudos como o feito por Reis (2008) e Brandão Janeira e Sampaio (2002), o rebote é ligado a vitórias no basquetebol, uma vez que ao recuperar a bola, a equipe defensora está impedindo que os atacantes pontuem, além dos rebotes defensivos terem ligação com o volume de jogo.

\subsubsection{Fintas e outros fundamentos}

Segundo Paes, Montagner e Ferreira (2009) nos fundamentos do basquetebol também existem fintas defensivas, da mesma forma como existem as ofensivas.

As fintas como ação defensiva, têm o intuito de ludibriar os atacantes, incidindo em situações de superioridade numérica defensiva ou a fim de levar o atacante a posições menos favoráveis dentro de quadra, favorecendo roubos de bola ou erros do adversário.

Ainda nos fundamentos defensivos, pode-se elencar tipos de marcação conforme as definições de Paes, Montanger e Ferreira (2009), porém, aqui ficaria muito caracterizado como situações individuais ou em grupo.

Um dos objetivos do trabalho é identificar fatores que levam os sistemas defensivos a sofrerem alterações, ou seja, será levado em consideração situações de $5 \times 5$, dessa forma os tipos de marcação serão abordados nos sistemas defensivos.

\subsection{Sistemas defensivos}

Os sistemas defensivos são organizações estratégico-táticas de uma equipe com objetivo de proteger a cesta. Ferreira e De Rose Jr. (2010) apontam que dentro dos sistemas defensivos, cada membro tem determinadas funções relacionadas às suas características físicas e técnicas, facilitando a aplicação. 
Paes, Montagner e Ferreira (2009) afirmam que equipes com sistemas mais estruturados e organizados, possivelmente têm vantagens sobre os adversários, tanto em aspectos ofensivos quanto em aspectos defensivos e de transição.

Para o presente trabalho, utilizaremos a divisão pedagógica utilizada por Duarte (2013) e Paes, Montagner e Ferreira (2009). Nas duas obras, sistemas defensivos são divididos em quatro grandes grupos: sistemas defensivos Individuais, zona, mistos ou combinadas e pressões. Na literatura, é possível encontrar divisões com três, cinco ou seis grandes grupos, porém, conteúdos não diferem estas divisões, servem para organização pedagógica dos conteúdos, ou por heterogeneidade encontrada pelos autores.

Porém, um fator deve ser levado em consideração para fins de análise e para o ensino do basquetebol, devido à evolução técnica, tática e até mesmo das regras da modalidade, atualmente, não é possível dizer que exista um sistema defensivo puro, como apontam Paes, Montagner e Ferreira (2009), ao afirmarem que alguns sistemas defensivos têm características de outros sem mudar sua estrutura, devido dinâmicas do jogo que foram mudando com a evolução do basquetebol.

\subsubsection{Sistemas defensivos individuais}

Os sistemas defensivos individuais são divididos em: simples, com flutuação, em linha de passe ou antecipação, com troca de marcação, com ajuda e visão orientada.

Os sistemas defensivos individuais têm como características situações de marcação $1 \times 1$ e são normalmente utilizados quando a equipe adversária tem em quadra, jogadores que podem desequilibrar o jogo individualmente aproveitando espaços dados por outros sistemas, além disso, dificulta o arremesso de média e longa distância (OLIVEIRA; PAES, 2004).

O sistema defensivo individual simples é o mais elementar das defesas individuais. Nele, cada defensor marca um adversário, mantendo-se entre jogador e cesta, até que aconteça qualquer alteração em que mude a dinâmica da marcação, logo, alterando o sistema defensivo.

Esse sistema já não é mais utilizado por equipes de alto rendimento, aparecendo mais nas fases iniciais da prática. 
No sistema defensivo com visão orientada, defensores se mantêm entre adversários que estão marcando e cesta, porém, mantêm a visão na bola. Esse sistema tem por característica a facilitação para outras manobras defensivas como flutuação e ajuda, ou seja, é facilitador de outros sistemas defensivos.

Os sistemas defensivos com ajuda têm como característica troca momentânea de marcação. Os defensores mantêm contato visual com seus marcadores e demais jogadores para evitar que alguma ação ofensiva coloque o sistema defensivo em desvantagem.

Caso algum atacante consiga vantagem sobre a defesa, fintando o marcador, um defensor faz a troca momentânea de marcação até o que defensor fintado recupere a posição.

No sistema defensivo individual com flutuação, defensores que estão do lado oposto da bola, mantendo uma determinada distância, "flutuam", se aproximando mais da cesta sem perder contato visual, evitando assim, possíveis ações do atacante com bola.

No sistema defensivo em linha de passe ou antecipação, defensores têm como objetivo antecipar possíveis linhas de passe, com o objetivo de impedir ou interceptar passes.

No sistema defensivo com troca de marcação, quando o defensor perde contato defensivo com o marcador, seja por finta ou por ação de corta luz, o jogador mais próximo deixa o marcador para acompanhar o atacante que está colocando o sistema defensivo em desequilíbrio. 


\subsubsection{Sistemas defensivos por zona}

Nos sistemas defensivos por zona, defensores têm por responsabilidade a marcação de espaços determinados dentro da quadra de defesa e seguem, prioritariamente, a movimentação da bola

Diferente dos sistemas defensivos individuais, as zonas dificultam infiltrações e arremessos de curta distância, porém, chances de conversão de arremessos de média e longa distância dos adversários aumentam (PAES; MONTAGNER; FERREIRA, 2009).

Os sistemas defensivos por zona são organizados em linhas defensivas, sendo que cada linha tem um determinado número de defensores. Segundo De Rose Jr. (2011), podem ser divididos em dois subgrupos, além de seus sistemas dentro de cada um dos grupos. Os sistemas defensivos por zona podem ser divididos em defesas pares e defesas ímpares e essa divisão é caracterizada pelo número de defensores na primeira linha defensiva.

Ainda segundo o mesmo autor, defesas pares são aquelas que têm dois jogadores na primeira linha defensiva são eles os sistemas: 2:1:2, 2:2:1 e 2:3 (figura 04). Já defesas ímpares se caracterizam pelo posicionamento de 1 ou 3 jogadores na primeira linha defensiva, são eles os sistemas: 1:2:2, 1:3:1, 1:1:3, 3:2, 1:1:2:1 e 1:2:1:1 (figura 05).

Figura 04 - Anagramas conjunto de defesas pares
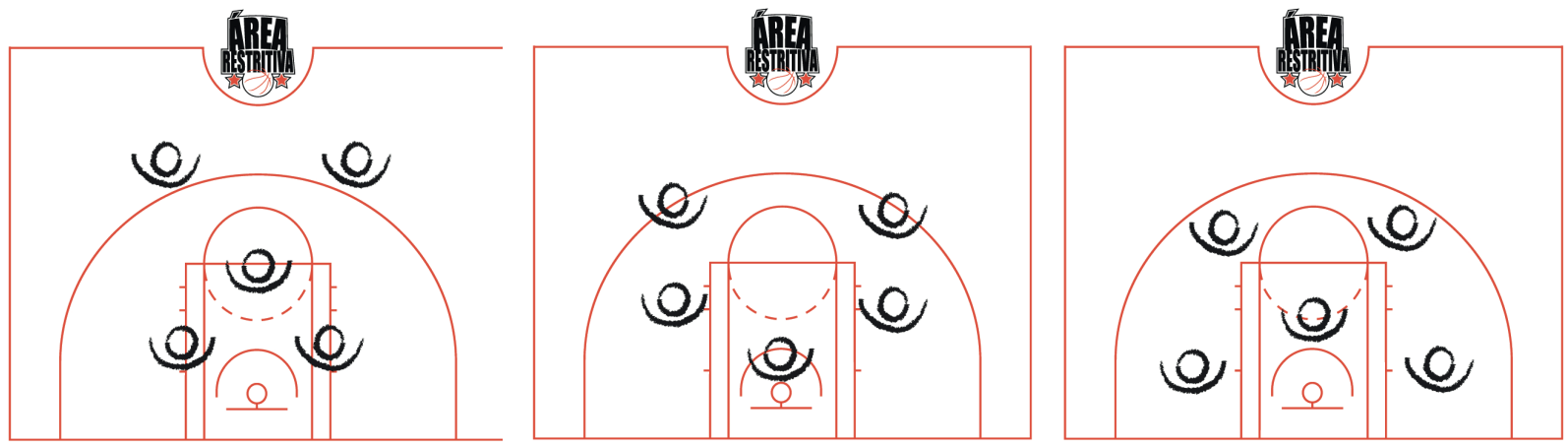

Fonte: Diego Leonardo de Andrade, 2019 
Figura 05 - Anagramas conjunto de defesas ímpares
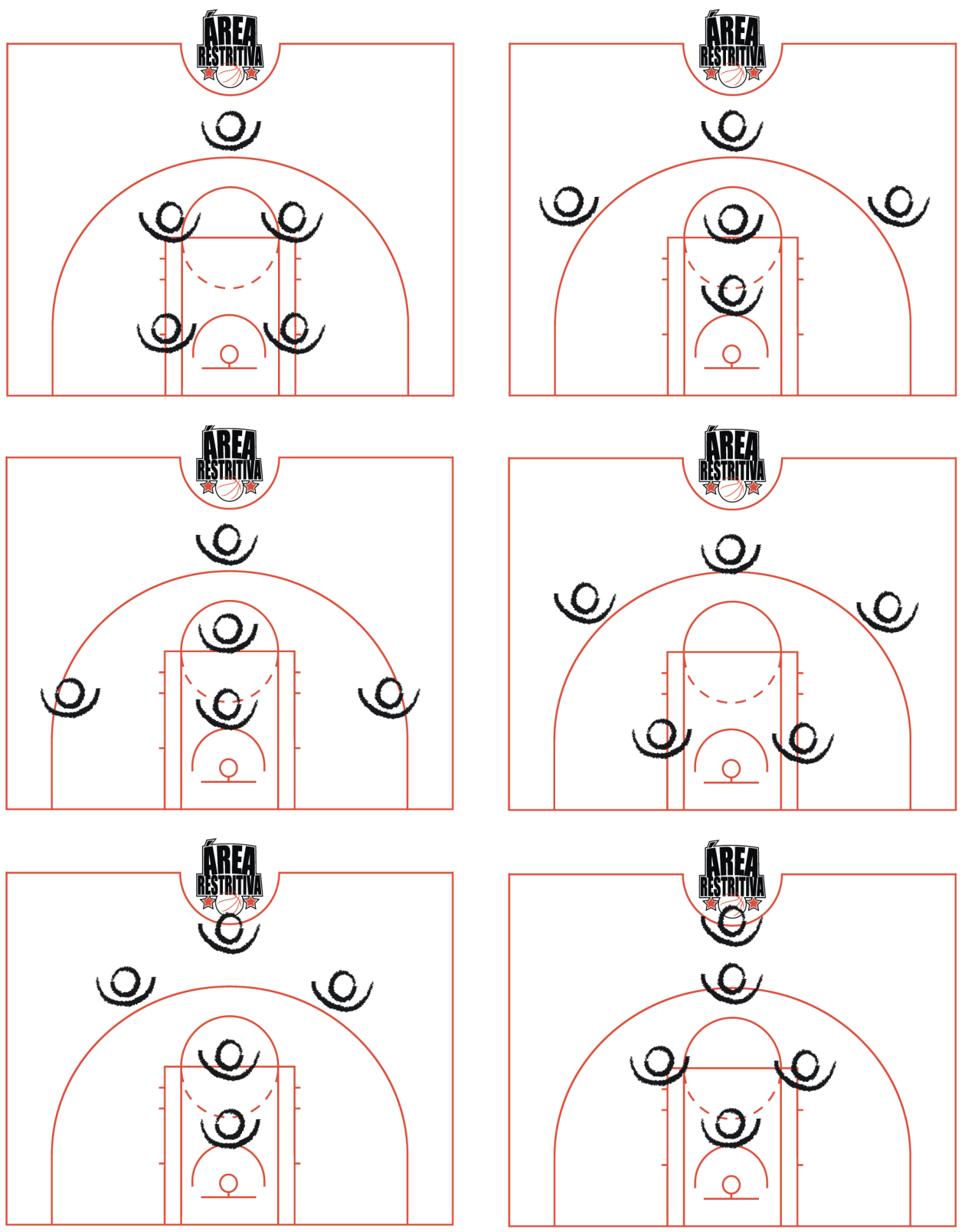

Fonte: Diego Leonardo de Andrade, 2019

\subsubsection{Sistemas defensivos mistos ou combinados}

Os sistemas defensivos mistos ou também chamados de combinados, são organizações defensivas com características dos sistemas defensivos individuais.

Seguindo definições de Paes, Montagner e Ferreira (2009) os sistemas defensivos mistos sãos divididos em box-one, diamond-one, triângulo-dois, três individual-dois em zona e match-up, com seus anagramas apresentados entre as figuras 06 à 10 . 
O box-one é um sistema misto, onde um dos defensores marca individualmente um dos atacantes e os demais defensores marcam em duas linhas defensivas com dois defensores, formando uma caixa ou quadrado. O atacante que é marcado individualmente, normalmente é o que pode desequilibrar o jogo individualmente.

Figura 06 - Anagramas sistema defensivo misto box-one

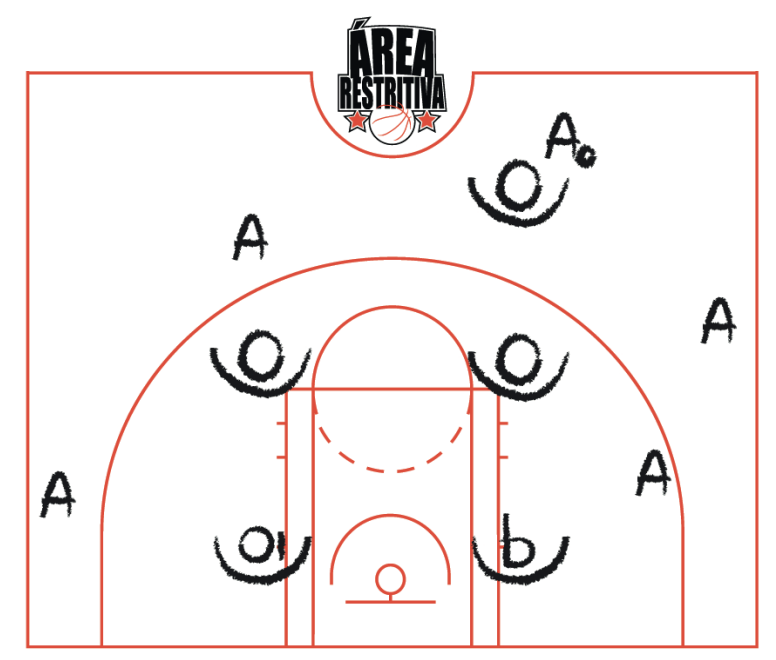

Fonte: Diego Leonardo de Andrade, 2019

A diamond-one é semelhante a box-one, um defensor marca um atacante, porém, atletas que defendem em zona estão em três linhas marcando 1:2:1, em um formato parecido com um diamante.

Figura 07 - Anagramas sistema defensivo misto diamond-one

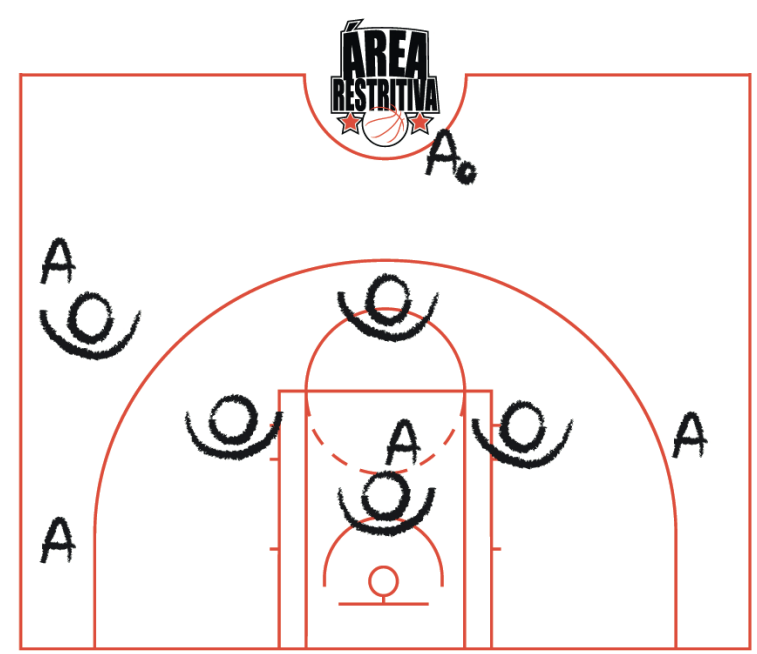

Fonte: Diego Leonardo de Andrade, 2019 
$\mathrm{Na}$ formação triângulo-dois, dois atletas marcam individualmente, assim, como nos sistemas anteriores, jogadores a serem marcados individualmente são os que podem desequilibrar o jogo tecnicamente, os demais se posicionam em duas linhas defensivas, marcando 1:2.

Figura 08 - Anagramas sistema defensivo misto triângulo-dois

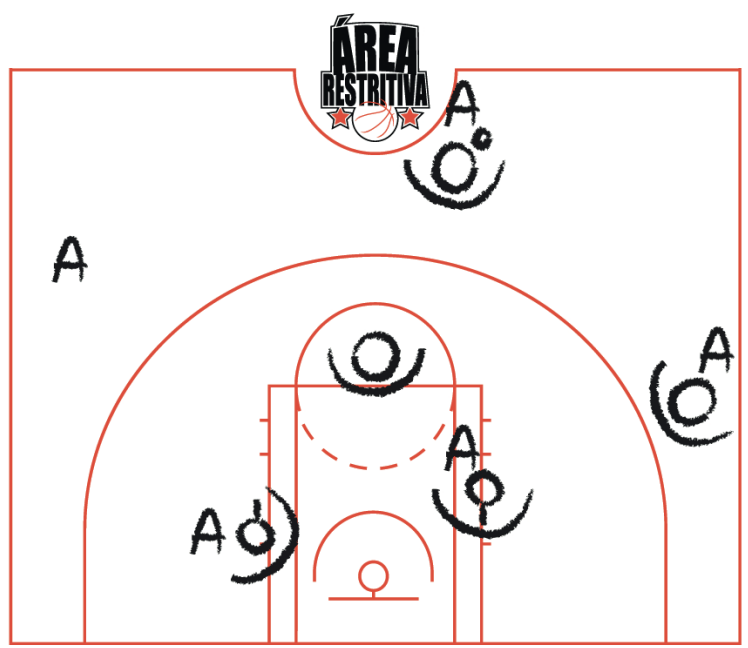

Fonte: Diego Leonardo de Andrade, 2019

Já na três individual-dois em zona, atletas que marcam em zona fazem duas linhas defensivas, cada uma com um jogador ou uma linha com dois atletas, nesse sistema, defensores que estão defendendo zona, defendem área predeterminadas, enquanto os outros três jogadores marcam os adversários individualmente.

Figura 09 - Anagramas sistema defensivo misto três individual-dois em zona

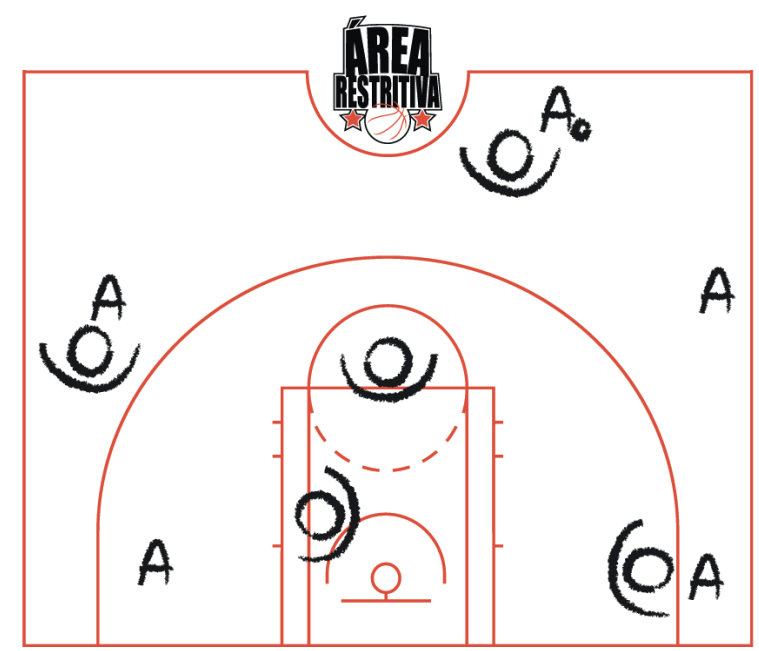

Fonte: Diego Leonardo de Andrade, 2019 
O sistema defensivo misto match-up é uma defesa considerada a mais complexa dentre os sistemas defensivos, esse sistema tem como característica unir sistemas defensivos individuais e zona em um mesmo sistema com o objetivo de igualar sempre a defesa e o ataque.

Esse sistema pode ser organizado com a defesa, marcando um sistema zona e em um determinado momento, todos os defensores passam a marcar individualmente. O mesmo pode acontecer com a defesa, utilizando marcação individual e passando a marcar em um sistema defensivo por zona, depois de uma determinada ação ofensiva.

Figura 10 - Conjunto de anagramas sistema defensivo misto match-up
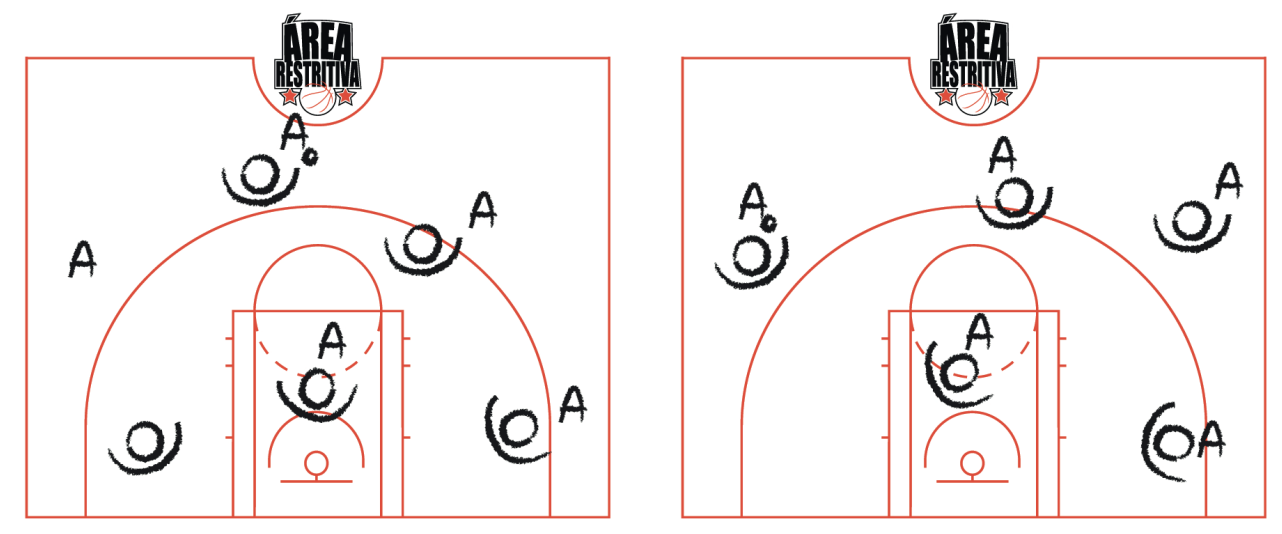

Fonte: Diego Leonardo de Andrade, 2019

Um exemplo de match-up seria após uma cesta efetuada pela equipe $B$, ela marca em um determinado sistema defensivo por zona, quando o armador atacante passa a bola para um dos alas, a defesa passa a defender em um sistema defensivo por zona, conforme exemplo na figura 10.

\subsubsection{Sistemas defensivos pressão}

Os sistemas defensivos pressão são subdivididos em dois grupos: pressão por zona e pressão individual. Grandes características desse bloco de sistemas são proporções da defesa e traps. 
Quanto as traps (figura 11) ou zonas de armadilhas, os sistemas defensivos pressão têm por característica favorecer situações de 2x1 pressionando o homem com a bola.

Defensores buscam levar atacantes para espaços que otimizem a chance de retomada de bola, nesse caso, cantos da quadra ou áreas delimitadas pelas linhas centrais e laterais ou linhas laterais e de fundo da quadra.

Figura 11 - Anagrama áreas de traps

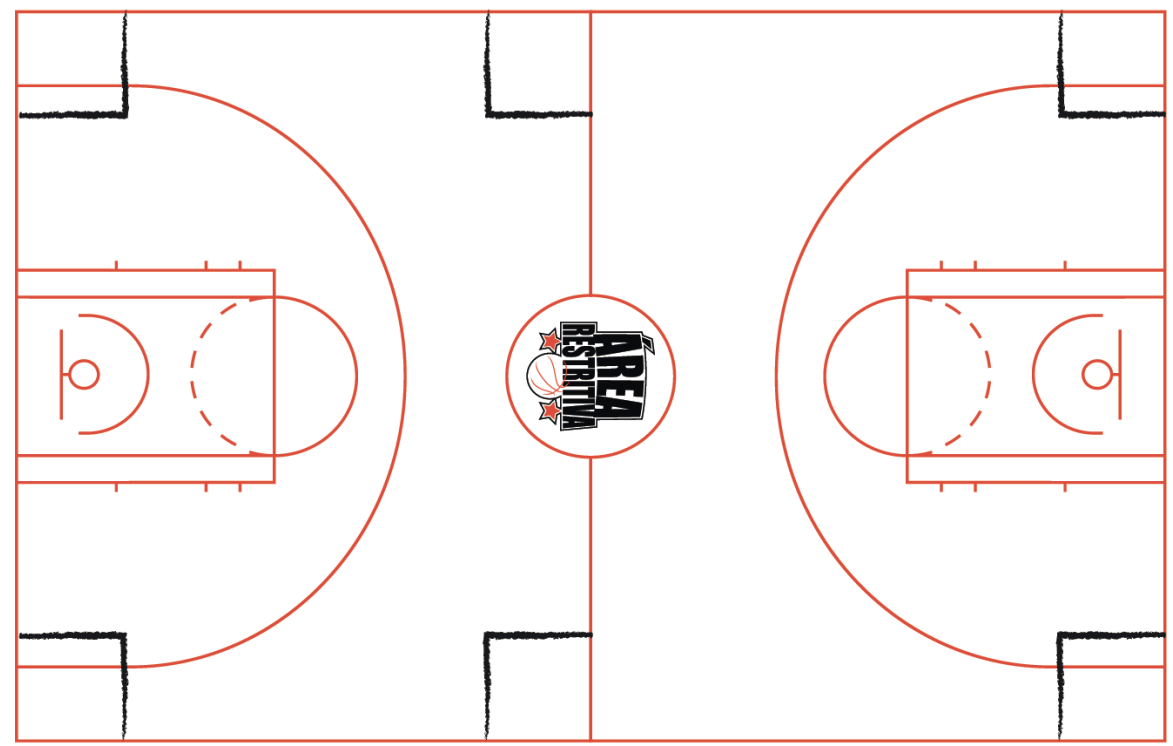

Fonte: Diego Leonardo de Andrade, 2019

Tanto pressões por zona quanto individuais devem levar em consideração espaços de atuação dos sistemas defensivos, ou seja, as proporções de abrangência da defesa dentro de quadra, podendo ser pressão quadra inteira, 3/4 de quadra, $1 / 2$ quadra e 1/4 de quadra, conforme apresentado na figura 12.

Em qualquer uma das proporções, todos os jogadores da defesa estão pressionando o ataque, com o objetivo de levar os atacantes a tomar decisões precipitadas devido à pressão dos jogadores da defesa. 
Figura 12 - Conjunto de anagramas sistema defensivo pressão zona 1:2:1:1
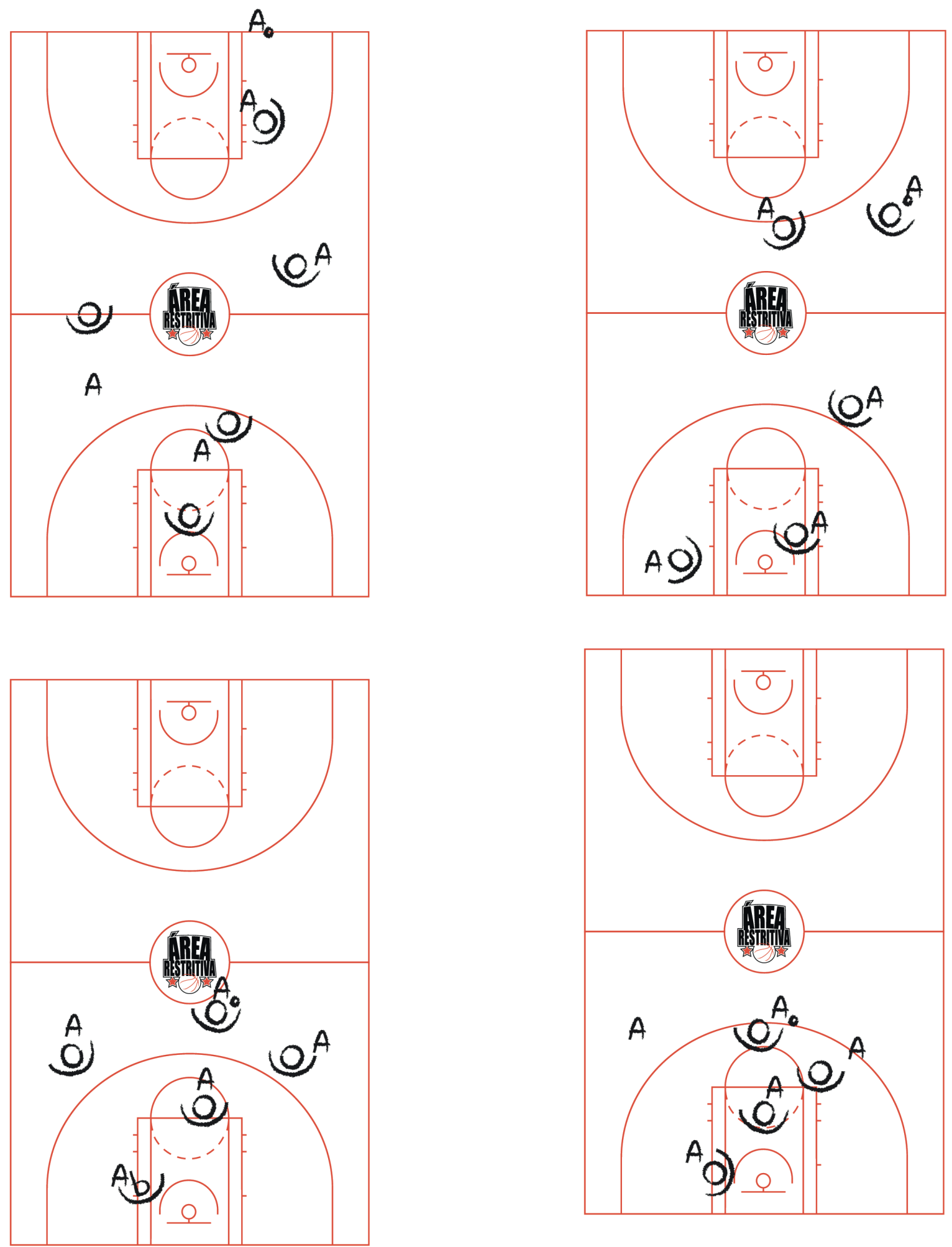

Fonte: Diego Leonardo de Andrade, 2019 
Atletas defensores ainda são guiados pela movimentação da bola, porém, existe pressão maior sobre a bola, objetivando levar o atacante para as zonas de armadilhas.

Apesar dos defensores poderem defender em proporções diferentes, o grande diferencial dos sistemas pressão é a agressividade dos mesmos que pressionam o tempo inteiro seus marcadores. Ferreira e De Rose Jr. (2010) alertam que em sistemas defensivos, defensores devem ter muita condição física para suportar marcar agressivamente os adversários.

Os autores também salientam que este tipo de sistema deve ser utilizado em momentos específicos para mudar o ritmo de jogo do adversário, mas ainda assim, pode ser utilizado por toda partida. 


\section{PROCESSOS E PROCEDIMENTOS METODOLÓGICOS DE PESQUISA}

O estudo foi aprovado pelo Comitê de Ética da Universidade de São Paulo sob o número 90932218.7 .0000 .5390$.

Para o cumprimento dos objetivos propostos pela pesquisa, o presente estudo consta de:

Fazer um levantamento histórico da evolução da defesa no basquetebol, para assim identificar quais são as ações defensivas coletivas dentro de um jogo formal de basquetebol brasileiro masculino adulto;

Identificar fatores que levaram os sistemas defensivos a sofrerem alterações, podendo ser elas simples mudanças de sistema empregado pela equipe, ou, mudanças em posturas e organização estratégico-tática.

Identificar como a defesa no basquetebol se articula na forma como o esporte é jogado atualmente, através de entrevistas com atletas, técnicos e especialistas da modalidade;

Para compor o corpus do trabalho, foram consultados 34 indivíduos, destes, 26 concordaram em participar do estudo, porém, somente 14 entrevistas foram selecionadas para a composição do estudo. Destes entrevistados, foram 2 ex-atletas, 7 técnicos, 1 árbitro e 4 especialistas.

Todos os entrevistados deveriam ter experiência mínima de três anos com equipes adultas de basquetebol masculino em suas áreas de atuação.

\subsection{A natureza da pesquisa}

O estudo foi baseado em uma abordagem qualitativa (SEVERINO, 2007) de natureza aplicada, conforme exposto por Thomas, Nelson e Silverman (2012), onde foram considerados aspectos qualitativos para a proposta desta pesquisa. 
As questões qualitativas do trabalho foram baseadas nos autores supracitados, que descrevem as pesquisas qualitativas como pesquisas altamente descritivas, sendo que elas não são passíveis de manipulação.

Para as cumprir com os objetivos do trabalho, foram feitas entrevistas individuais de profundidade (GASKELL, 2015), com técnicos de basquetebol, exatletas, árbitros e especialistas da modalidade, sendo esses comentaristas esportivos, todos com experiência mínima de três anos em suas áreas, com equipes adultas masculinas.

O método empregado foi a entrevista narrativa, baseada em tópico guia, conforme definições (JOVCHELOVITCH; BAUER, 2015) e descrito no quadro 5, todas as entrevistas foram feitas pessoalmente ou através de chamadas telefônicas, via Skype.

As entrevistas realizadas pessoalmente foram gravadas em formato MP3 através do aplicativo para iOS "Gravador de Voz", versão 8.4.0, já as entrevistas feitas via Skype serão gravadas em formado mp4 através do programa para macOX “Callnote", versão 5.6.4.

Quadro 05 - Tópico guia - estrutura da entrevista narrativa

\begin{tabular}{|c|c|}
\hline Sequência & Perguntas \\
\hline 1 & Preparação: Agradecimento e explicação da pesquisa. \\
\hline 2 & Início: Começar gravação e apresentar o tópico inicial. \\
\hline 3 & $\begin{array}{l}\text { Narração central: defesa no basquetebol, o informante deve apresentar uma } \\
\text { visão geral do basquetebol atual, falando sobre o Basquetebol Masculino } \\
\text { brasileiro e a evolução do jogo. }\end{array}$ \\
\hline \multirow[t]{10}{*}{4} & $\begin{array}{l}\text { Fase de questionamento: transformando o tópico guia em perguntas } \\
\text { imanentes abordar com as palavras do informante: }\end{array}$ \\
\hline & a- Aspectos defensivos no basquetebol. \\
\hline & b- Fundamentos técnico-táticos. \\
\hline & c- Conhecimento do jogo. \\
\hline & d- Conhecimento da relação ataque $x$ defesa esperado dos atletas. \\
\hline & e- Disso o que é essencial. \\
\hline & f- Sobre a Classificação da defesa. \\
\hline & g- Fundamentos defensivos individuais e grupais. \\
\hline & h- Fundamentos defensivos coletivos. \\
\hline & i- Uma sugestão de classificação defensiva. \\
\hline
\end{tabular}


Fonte: Desenvolvida pelo próprio autor (2018)

As entrevistas têm como objetivo identificar como sistemas defensivos se articulam no Basquetebol Brasileiro Masculino De Alto Rendimento, visto a constante evolução do esporte.

Para o tratamento dos dados coletados nas entrevistas, optou-se pelo método de análise de conteúdo de Bardin (2016), que segundo a autora, é a "inferência de conhecimentos relativos às condições de produção, inferência esta que recorre a indicadores" (p.44).

O método de análise de conteúdo foi organizado em três momentos: préanálise, exploração do material e tratamento dos resultados. Cada um desses momentos tem características distintas e em alguns casos, outras subdivisões.

A pré-análise corresponde ao momento de tornar operacionais e sistematizar ideias iniciais. Para que isso seja possível, é necessária a leitura flutuante dos conteúdos a serem analisados para as primeiras impressões sobre os dados.

Ela ainda pode ser dividida em outras três partes, que são: escolha dos documentos, formulação das hipóteses e objetivos e elaboração de indicadores que fundamentem a interpretação final.

A primeira parte da pré-análise é a escolha dos documentos. Nesse momento, são definidos o corpus, nesse caso, entrevistas narrativas, para assim estipular regras e critérios necessários, preparando o material para cumprir necessidades da pesquisa.

Duas regras são levadas em consideração nesta pesquisa: regra da exaustividade, que diz que quando o corpus é definido, nenhum item dele é deixado de lado, outra regra é da homogeneidade, que diz que documentos utilizados devem obedecer precisamente ao critério de escolha. Nesse caso, entrevistas foram feitas com indivíduos com experiência mínima de três anos, com equipes profissionais de basquetebol, sendo essas equipes adultas.

Seguindo para a formulação das hipóteses e objetivos, porém, nem sempre é necessária a composição de um guia de hipóteses, optando assim por procedimentos de exploração, onde, a partir das próprias entrevistas é possível aprender ligações de variáveis dentro dos conteúdos. 
Sendo assim, nessa pesquisa, não foram elaborados hipóteses e indicadores para as análises das entrevistas. Porém, as entrevistas seguem o tópico guia de itens a serem abordados, apresentado na tabela 05.

Com três partes seguidas, técnicas de análise são testadas e dados são preparados para a análise a ser feita na exploração do material, nesse caso, as entrevistas são transcritas, alinhando e estruturando conteúdos para possíveis comentários e notas feitas durante o contato com documentos a serem analisados.

A técnica de análise empregada foi a análise da enunciação. A característica principal desta técnica é que cada entrevista é tratada como um processo e não como um dado, sendo que cada entrevista é estudada em si mesma como uma totalidade.

Quanto a segunda fase, a exploração do material consistiu na aplicação sistemática das decisões tomadas é foi momento em que as operações de codificação, decomposição ou enumeração, em função das regras previamente formuladas. Nesta fase a categorização das análises é estabelecida, juntamente com as unidades de registro e de contexto.

Iniciando a última fase da análise de conteúdo, o tratamento dos resultados, com categorias estabelecidas e resultados brutos das análises.

A partir daqui, aconteceram inferências e interpretações dos resultados obtidos e para este estudo foi o momento que que apareceram o contraponto entre o objetivo das entrevistas e o instrumento de análise previamente estruturado, que foi composto de indicadores de observação, relacionados a componentes técnicos e tático-estratégicos do jogo. Todos os indicadores estiveram relacionados a situações defensivas no basquetebol, conforme exposto anteriormente.

A análise de conteúdo segue em fluxograma de ações exposto na figura 13: 
Figura 13 - Fluxograma de desenvolvimento de análise

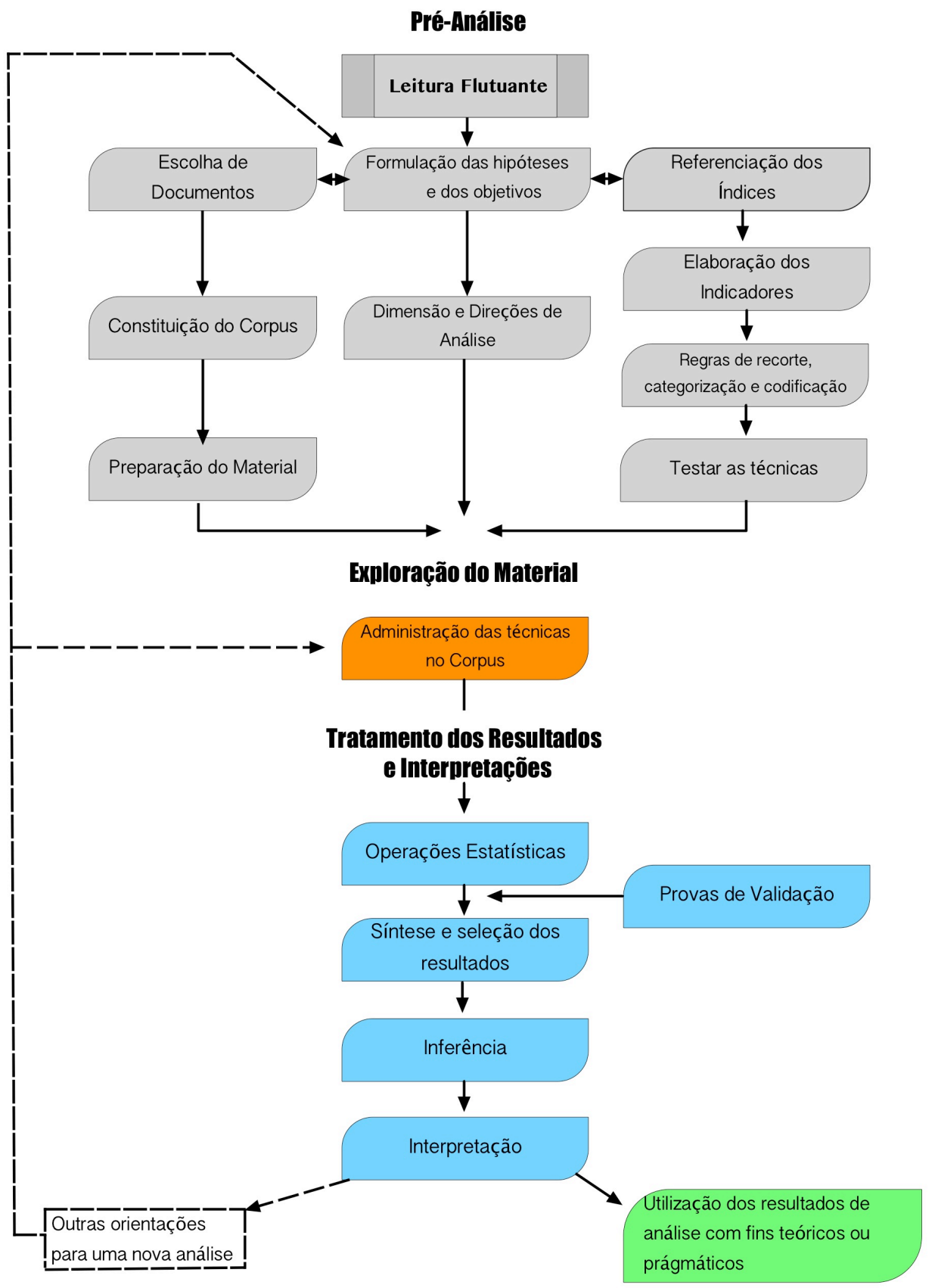

Fonte: Extraído de Bardin (2016, p.132)

Sendo assim, segundo Bardin (2016), o desenvolvimento da análise das entrevistas narrativas feitas para o presente estudo foram estruturadas de acordo com a figura 14 : 
Figura 14 - Fluxograma de desenvolvimento de análise

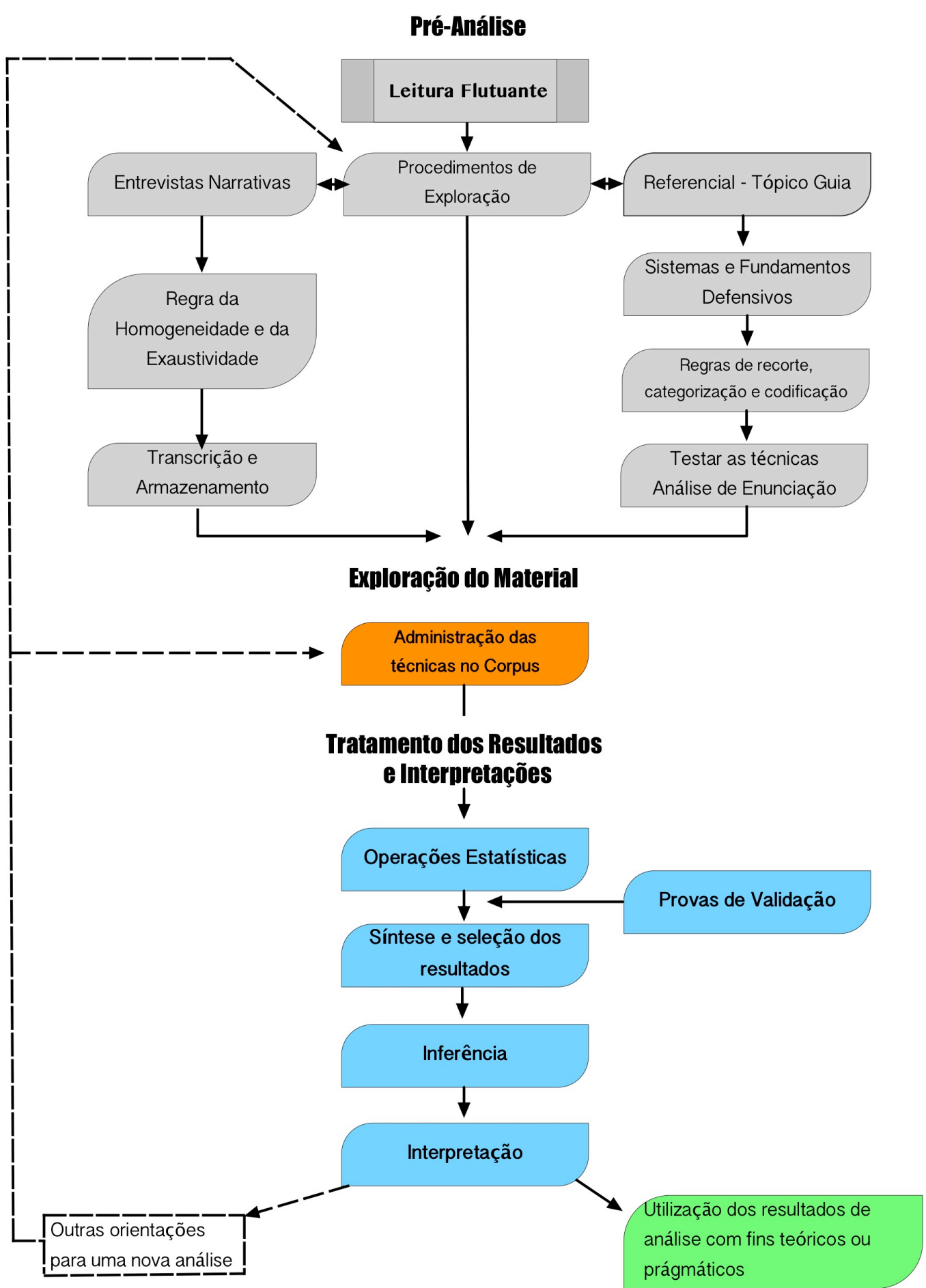

Fonte: Adaptado de Bardin (2016, p.132) 


\section{APRESENTAÇÃO DOS RESULTADOS}

Seguindo a metodologia proposta, os dados foram analisados e divididos em grupos focais. Ao todo, foram criados 103 grupos focais, sendo que para a formação desses grupos, não foi considerado o significado do termo relacionado ao grupo focal, mas sim, o contexto ao qual ele estava inserido, tratando assim, a narrativa como um processo e não como um dado, seguindo critérios da Análise de Enunciação (BARDIN, 2016).

Os grupos formados depois da interpretação e criação das unidades de registro e contexto, foram nomeados conforme apresentados na quadro 06 :

Quadro 06 - Descrição dos grupos focais formados/unidades de registro e contexto

\begin{tabular}{|c|c|}
\hline Ajuda & Fundamento técnico individual. \\
\hline Antecipação & Fundamento técnico individual. \\
\hline Aprimoramento técnico & $\begin{array}{l}\text { Agrupamento de significados relacionados ao } \\
\text { desenvolvimento positivo de fundamentos técnicos. }\end{array}$ \\
\hline Arremessadores Eficientes & Taxa de conversão de arremesso em cesta alta. \\
\hline Atleticísmo & $\begin{array}{l}\text { Termo relacionado a aumento da estatura, força física } \\
\text { envergadura e outras valências físicas dos atletas. }\end{array}$ \\
\hline Aumento do Repertório & Repertório técnico dos atletas mais abrangentes. \\
\hline Comunicação & Comunicação dentro e fora de quadra. \\
\hline Condicionamento Físico & $\begin{array}{l}\text { Termo relacionado ao trabalho de preparação física } \\
\text { dos atletas. }\end{array}$ \\
\hline Conduzir o adversário & $\begin{array}{l}\text { Relacionado a defesa que consegue conduzir o } \\
\text { adversário para o lado que deseja. }\end{array}$ \\
\hline $\begin{array}{l}\text { Conhecimento Técnico/Tático - } \\
\text { Atleta }\end{array}$ & $\begin{array}{l}\text { Conhecimentos técnicos e táticos (Téc/Tát) } \\
\text { relacionados ao entendimento do jogo propriamente } \\
\text { dito por parte do atleta }\end{array}$ \\
\hline $\begin{array}{l}\text { Conhecimento Técnico/Tático - } \\
\text { Técnicos }\end{array}$ & $\begin{array}{l}\text { Conhecimentos técnicos e táticos (Téc/Tát) } \\
\text { relacionados ao entendimento do jogo propriamente } \\
\text { dito por parte do técnico. }\end{array}$ \\
\hline Controle do Tempo & $\begin{array}{l}\text { Relacionado ao controle do jogo em relação ao tempo } \\
\text { de partida. }\end{array}$ \\
\hline Corta-Luz & Fundamento individual propriamente dito. \\
\hline Defesa Motivada & $\begin{array}{l}\text { Atletas motivados para desempenhar seu papel na } \\
\text { defesa. }\end{array}$ \\
\hline $\begin{array}{l}\text { Desenvolvimento de Capaci e } \\
\text { Habili }\end{array}$ & $\begin{array}{l}\text { Desenvolvimento de capacidades físicas e habilidades } \\
\text { motoras. }\end{array}$ \\
\hline Deslocamento Defensivo & $\begin{array}{l}\text { Agrupamento relacionado à movimentação dos } \\
\text { defensores e o trabalho de pernas realizado por eles. }\end{array}$ \\
\hline Diminuição de Espaço & $\begin{array}{l}\text { Diminuição de espaço para ações do jogo } \\
\text { propriamente dito. }\end{array}$ \\
\hline
\end{tabular}


Direcionamento Defensivo

Disposição

Dobra

Ensinar a Jogar

Especialização Técnica

Estruturação

Falta de Metodologia

Flutuar

Footwork

Formação

Imposição

Individual

Instabilidade Tática

Intensidade

Intimidação

Investimento

Jogadores Universais

Jogo Coletivo

Jogo Conceito

Jogo com mais contato

Jogo de Transição

Jogo Individualizado

Jogo Rápido

Leitura de Jogo

Maior Contato Físico
Grupo similar ao "conduzir o adversário", porém aqui apresentado em outra categoria e em um outro contexto.

Agrupamento similar ao "defesa motivada", mas aqui relacionado a como os jogadores se portam em quadra.

Fundamento defensivo individual.

Agrupamento relacionado ensinar a compreensão do jogo.

Relacionado a especialização em determinados fundamentos técnicos ou maneiras de jogar.

Melhores ginásios, tecnologias de captação de imagem.

Falta de um padrão de métodos de ensino.

Fundamento individual defensivo.

Trabalhos coordenativos de membros inferiores relacionados a preparação física, mas um conteúdo diferenciado.

Formação de atletas, trabalho formativo.

Agrupamento relacionado a postura do jogador em quadra, da forma como ele se impõe perante os adversários.

Sistema defensivo individual.

Agrupamento relacionado a falta de um padrão tático no basquetebol nacional, ou o período de transição gerando essa instabilidade.

Relacionado a defender de forma intensa.

Agrupamento de significado semelhante ao "imposição".

Aporte financeiro direto no esporte. Jogadores que atuam em mais de uma posição ou função.

Agrupamento de frases que remetem o jogo de 5 contra 5, ou a importância de se preocupar com os companheiros de equipe.

Jogo baseado em conceitos, regras ou ações combinadas previamente pela comissão técnica e atletas.

Maior contato físico permitido nas partidas. Relacionado ao Jogo de Transição propriamente dito. Agrupamento de frases opostas ao "jogo coletivo". Frases que remetem a velocidade de conclusão do ataque.

Agrupamento de frases que remetem a leitura ou entendimento do jogo e seus acontecimentos. Agrupamento semelhante ao "jogo com mais contato". 


\begin{tabular}{|c|c|}
\hline Métodos & $\begin{array}{l}\text { Agrupamento relacionado a maneiras de se ensinar o } \\
\text { basquetebol. }\end{array}$ \\
\hline Mista & Sistema defensivo misto ou combinado. \\
\hline Motivação & $\begin{array}{l}\text { Agrupamento relacionados a fatores motivadores para } \\
\text { o atleta. }\end{array}$ \\
\hline Mudança de Conteúdo & $\begin{array}{l}\text { Referente ao momento em que segundo os } \\
\text { informantes o basquetebol se encontra. }\end{array}$ \\
\hline Nomenclaturas & $\begin{array}{l}\text { Agrupamento relacionado a um padrão de termos } \\
\text { técnicos relacionados ao esporte. }\end{array}$ \\
\hline Ocupação de Espaço & $\begin{array}{l}\text { Agrupamento relacionado a ocupação de espaço } \\
\text { propriamente dita em partidas de basquetebol. }\end{array}$ \\
\hline Organização Tática & $\begin{array}{l}\text { Agrupamento de informações relacionadas a } \\
\text { conteúdos táticos expostos para um melhor } \\
\text { desempenho das equipes. }\end{array}$ \\
\hline Posicionamento & $\begin{array}{l}\text { Posicionamento do atleta em quadra, ex.: Jogador está } \\
\text { entre o atacante e a cesta. }\end{array}$ \\
\hline Postura & $\begin{array}{l}\text { Postura do atleta em quadra, ex.: quadril e Joelhos } \\
\text { flexionados. }\end{array}$ \\
\hline Pressão & Sistemas defensivos pressão. \\
\hline Pressão Psicológica & $\begin{array}{l}\text { Agrupamento com frases relacionadas a pressão } \\
\text { psicológica. }\end{array}$ \\
\hline Profissionalismo - Atleta & $\begin{array}{l}\text { Agrupamento que diz respeito ao atleta dedicado, que } \\
\text { se cuida e/ou que faz treinos extras. }\end{array}$ \\
\hline Qualificação & $\begin{array}{l}\text { Agrupamento de frases em que foi evidenciado a } \\
\text { procura por melhor qualificação dos profissionais } \\
\text { envolvidos. }\end{array}$ \\
\hline Rebote & Fundamento defensivo/ofensivo individual. \\
\hline Regra & $\begin{array}{l}\text { Agrupamento de frases ou momentos em que as regras } \\
\text { do jogo foram evidenciadas. }\end{array}$ \\
\hline Regra Três Segundos & Regra de três segundos ofensiva da NBA. \\
\hline Regras brandas & $\begin{array}{l}\text { Agrupamento que relaciona o não cumprimento de } \\
\text { algumas regras ou a não aplicação das mesmas. }\end{array}$ \\
\hline Rotação Defensiva & $\begin{array}{l}\text { Agrupamento que relaciona momentos em que os } \\
\text { defensores trocam quais os atacantes estão } \\
\text { defendendo. }\end{array}$ \\
\hline Scout & $\begin{array}{l}\text { Agrupamento relacionado a análise qualitativa de jogos } \\
\text { de basquetebol. }\end{array}$ \\
\hline Sistematização do Jogo & $\begin{array}{l}\text { Agrupamento que relaciona à criação de jogadas ou } \\
\text { padrões de jogo (sistemas de jogo). }\end{array}$ \\
\hline Técnica/Execução & $\begin{array}{l}\text { Agrupamento que relaciona frases que se referem a } \\
\text { execução técnica de fundamentos. }\end{array}$ \\
\hline Tecnologia & $\begin{array}{l}\text { Agrupamento que relaciona o uso de tecnologia no } \\
\text { basquetebol. }\end{array}$ \\
\hline Tempo de Reação Menor & Diminuição do tempo de reação. \\
\hline Treinamento Cognitivo & Referências ao treinamento e/ou preparação cognitiva. \\
\hline
\end{tabular}




\begin{tabular}{|ll|}
\hline Treinamento Psicológico & $\begin{array}{l}\text { Referências ao treinamento e/ou preparação } \\
\text { psicológica. }\end{array}$ \\
\hline Troca & $\begin{array}{l}\text { Agrupamento relacionado ao fundamento individual } \\
\text { troca, ou no caso do sistema defensivo uma espécie de } \\
\text { match-up. }\end{array}$ \\
& $\begin{array}{l}\text { Agrupamento relacionado ao intercâmbio de } \\
\text { informações realizados hoje em dia, ex.: técnicos } \\
\text { viajando para acompanhar outras competições ou } \\
\text { treinamentos de outras equipes. }\end{array}$ \\
Troca de Informação & $\begin{array}{l}\text { Agrupamento relacionado aos valores ensinados } \\
\text { através do esporte. }\end{array}$ \\
Valores & $\begin{array}{l}\text { Agrupamento relacionado a pluralidade de sistemas e } \\
\text { fundamentos defensivos utilizados em conjunto. }\end{array}$ \\
Variações Defensivas & Fundamento defensivo individual visão orientada. \\
Visão Orientada & Sistema defensivo por zona. \\
\hline Zona &
\end{tabular}

Fonte: Diego Leonardo de Andrade, 2019

Os grupos foram classificados em característica do jogo, tipos de sistemas defensivos, fundamentos técnico/táticos (Fund Téc/Tát.), o que tem (fator positivo), o que falta (fator negativo) e momento histórico.

As entrevistas estão disponíveis na íntegra em anexo.

\subsection{Resultados}

A tabela 01 refere-se ao tópico inicial das entrevistas, os primeiros grupos focais foram formados, esses apresentados na tabela não refletem a quantidade de vezes que o termo ou frase surgem na narrativa, mas sim, se eles aparecem. Porém, devido a pluralidade de grupos, impossibilita uma tendência na visão do que seria o basquetebol atual.

Porém, pode-se dizer que o basquetebol atual é caracterizado pelo jogo de transição e o controle do tempo ou da posse de bola e a pressão que diz respeito a pressão sobre a bola e não o sistema defensivo, além do atleticísmo.

Quanto aos fundamentos técnico-táticos, o rebote aparece com maior frequência. Um destaque dos fatores positivos é o aumento do conhecimento técnicotático dos técnicos de basquetebol, assim como o jogo coletivo, que remete de certa forma ao jogo conceito. 
A pressão psicológica colocada como algo que falta no jogo, remete a como lidar com pressão psicológica e às vezes, como aplicar essa pressão, algo que aparece como positivo é a preocupação em treinamentos psicológicos.

Identificando como o momento histórico do basquetebol é o momento de maior contato. Atualmente, entendesse que devido ao aumento da estatura e de jogadores mais fortes fisicamente, o maior contato é permitido durante as partidas.

Tabela 01 - Conjunto de categorias - tópico inicial

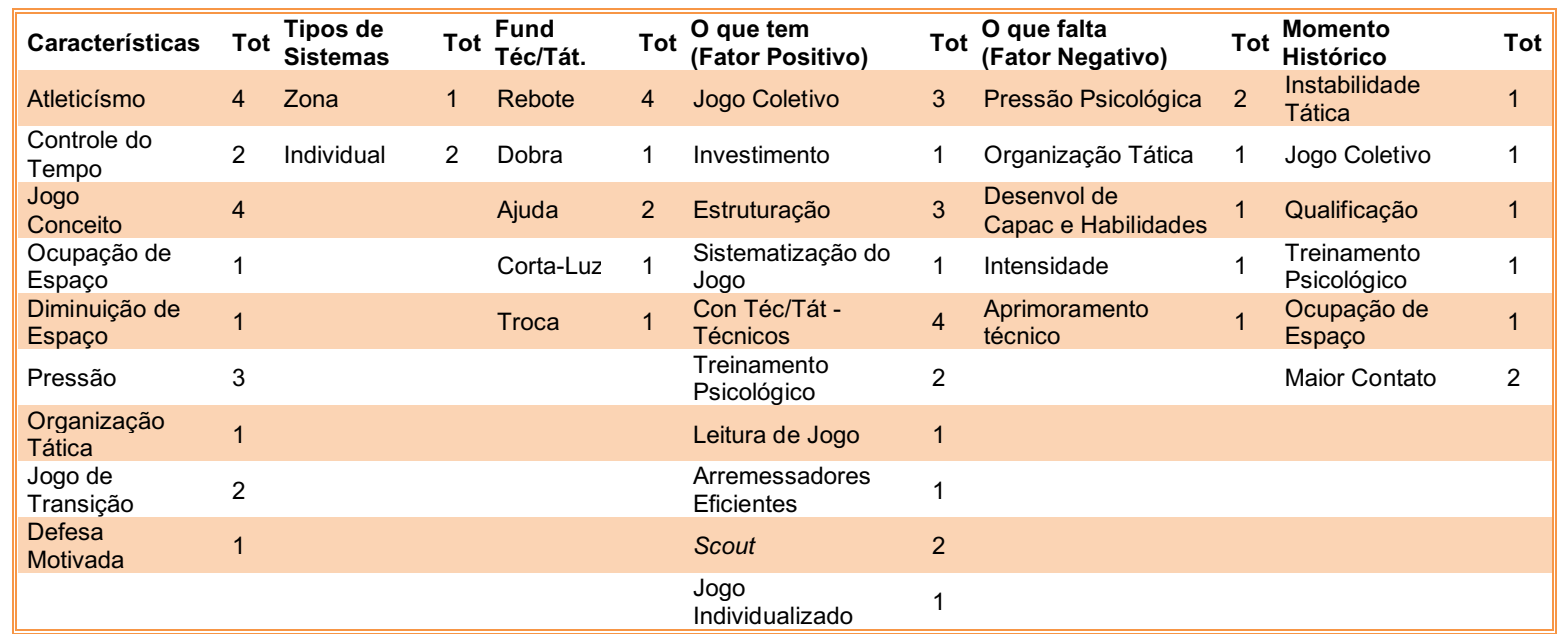

Fonte: Diego Leonardo de Andrade, 2019

A tabela 02 apresenta a categorização dos aspectos e evolução defensivos levados em consideração nas narrativas, como característica, aparecem alguns grupos que apareceram anteriormente no primeiro conjunto de categorias apresentado, com destaque mais uma vez para o atleticísmo e para o jogo conceito.

$\mathrm{Na}$ coluna tipos de sistemas, os mesmos sistemas defensivos são citados e seguindo para fundamentos técnico/táticos, a única categoria sem nenhum grupo focal formado, fator curioso, já que essa tabela é referente aos aspectos e a evolução defensiva.

Apesar de em menor incidência, um grupo diferente aparece em fator positivo, o jogo individual contrapondo o jogo coletivo que aparece duas vezes, um dos destaques junto com leitura de jogo.

Dois novos grupos aparecem no fator negativo e eles de certa forma, estão ligados à falta de técnica ou execução falha de fundamentos que está ligada à falta de grupos focais na categoria fundamentos técnico/táticos e o profissionalismo do 
atleta. Essas duas têm relação aos atletas que treinam fundamentos técnicos e dedicam-se aos treinamentos, um tem influência direta no outro.

Maior contato físico aparece mais uma vez relacionada ao momento histórico da modalidade:

Tabela 02 - Conjunto de categorias - aspectos/evolução defensiva

\begin{tabular}{|c|c|c|c|c|c|c|c|c|c|c|}
\hline Características & Tot & $\begin{array}{l}\text { Tipos de } \\
\text { Sistemas }\end{array}$ & Tot $\begin{array}{l}\text { Fund } \\
\text { Téc/Tát. }\end{array}$ & Tot & $\begin{array}{l}\text { O que tem } \\
\text { (Fator Positivo) }\end{array}$ & Tot & $\begin{array}{l}\text { O que falta } \\
\text { (Fator Negativo) }\end{array}$ & Tot & $\begin{array}{l}\text { Momento } \\
\text { Histórico }\end{array}$ & Tot \\
\hline Jogo Conceito & 3 & Individual & 1 & & $\begin{array}{l}\text { Con Téc/Tát - } \\
\text { Técnicos }\end{array}$ & 1 & Técnica/Execução & 1 & $\begin{array}{l}\text { Condicionamento } \\
\text { Físico }\end{array}$ & 1 \\
\hline Atleticísmo & 4 & Zona & 1 & & Motivação & 1 & $\begin{array}{l}\text { Profissionalismo - } \\
\text { Atleta }\end{array}$ & 1 & Jogo Rápido & 1 \\
\hline $\begin{array}{l}\text { Jogo de } \\
\text { Transição }\end{array}$ & 2 & & & & Jogo Coletivo & 2 & & & $\begin{array}{l}\text { Jogadores } \\
\text { Universais }\end{array}$ & 1 \\
\hline $\begin{array}{l}\text { Aumento do } \\
\text { Repertório }\end{array}$ & 1 & & & & Leitura de Jogo & 2 & & & $\begin{array}{l}\text { Maior Contato } \\
\text { Físico }\end{array}$ & 1 \\
\hline $\begin{array}{l}\text { Ocupação de } \\
\text { Espaço }\end{array}$ & 1 & & & & Comunicação & 1 & & & $\begin{array}{l}\text { Variações } \\
\text { Defensivas }\end{array}$ & 1 \\
\hline Pressão & 1 & & & & Jogo Individual & 1 & & & & \\
\hline Disposição & 1 & & & & & & & & & \\
\hline
\end{tabular}

Fonte: Diego Leonardo de Andrade, 2019

A tabela 03 apresenta grupos retirados da narrativa apresentada pelos informantes é relacionada aos fundamentos técnico-táticos e interação entre ataque e defesa no jogo de basquetebol.

O atleticísmo aparece mais uma vez em destaque quanto às características do jogo, além de quando colocado o momento histórico do basquetebol, o condicionamento físico aparece. Dessa forma, entende-se que o atleticísmo, ligado ao condicionamento físico dos atletas, é apontado como característica para melhor desempenho dos fundamentos técnicos-táticos.

Fundamentos técnicos-táticos apontados footwork, deslocamento defensivo e posicionamento, considerando o footwork como um fundamento e não como somente um conteúdo presente na preparação física, pode-se relacionar todas essas categorias e identificar a relação, cruzando referências de outros itens de outras categorias como a leitura do jogo, tempo de reação a pressão e a ocupação de espaço.

Um fator negativo de grande destaque até aqui é a falta de leitura de jogo, porém, o mesmo item aparece como um fator positivo do jogo, porém, com menor número de grupos focais. 
Tabela 03 - Conjunto de categorias - fund. téc/tát e ataque $\mathrm{x}$ defesa

\begin{tabular}{|c|c|c|c|c|c|c|c|c|c|c|c|}
\hline Características & Tot & $\begin{array}{l}\text { Tipos de } \\
\text { Sistemas }\end{array}$ & Tot & $\begin{array}{l}\text { Fund } \\
\text { Téc/Tát. }\end{array}$ & Tot & $\begin{array}{l}\text { O que tem } \\
\text { (Fator Positivo) }\end{array}$ & Tot & $\begin{array}{l}\text { O que falta } \\
\text { (Fator Negativo) }\end{array}$ & Tot & $\begin{array}{l}\text { Momento } \\
\text { Histórico }\end{array}$ & Tot \\
\hline Atleticísmo & 3 & Individual & 1 & Footwork & 3 & Leitura de Jogo & 2 & Ensinar a Jogar & 1 & $\begin{array}{l}\text { Condicionamento } \\
\text { Físico }\end{array}$ & 1 \\
\hline Pressão & 1 & & & Rebote & 1 & Comunicação & 2 & Leitura de Jogo & 3 & $\begin{array}{l}\text { Rotação } \\
\text { Defensiva }\end{array}$ & 1 \\
\hline $\begin{array}{l}\text { Ocupação de } \\
\text { Espaço }\end{array}$ & 1 & & & $\begin{array}{l}\text { Deslocamento } \\
\text { Defensivo }\end{array}$ & 2 & $\begin{array}{l}\text { Tempo de } \\
\text { Reação Menor }\end{array}$ & 1 & Profissionalismo & 1 & Jogo mais físico & 1 \\
\hline \multirow[t]{2}{*}{ Jogo Conceito } & 1 & & & Posicionamento & 2 & & & $\begin{array}{l}\text { Conhecimento } \\
\text { Téc/Tat - Atleta }\end{array}$ & 1 & & \\
\hline & & & & Antecipação & 1 & & & Regras brandas & 1 & & \\
\hline
\end{tabular}

Fonte: Desenvolvida pelo próprio autor

A tabela 04 apresenta a categorização da narrativa sobre o conhecimento do jogo, o mesmo fenômeno que foi apresentado na tabela 08 se repete aqui, porém, em uma categoria diferente, dessa vez, em tipos de sistemas.

$\mathrm{O}$ atleticísmo e o jogo conceito aparecem mais uma vez como características do conhecimento do jogo e a relação ataque $\mathrm{x}$ defesa no basquetebol.

Os fundamentos técnicos apresentam novo grupo, algo recorrente ao jogo coletivo e a pressão, que são grupos focais apresentados na categoria características, a rotação defensiva, além da ajuda que também pode ter ligação com rotação defensiva, com a pressão e é abordada pelos entrevistados em suas falas.

A leitura de jogo é o grupo focal com o maior número de incidências, não só da sua categoria, mas de toda a tabela 08 , o conhecimento técnico/tático do atleta e do técnico também aparecem como fatores positivos e a comunicação em quadra, todos esses grupos podem ter ligação direta quando relacionados ao conhecimento do jogo e a relação ataque $x$ defesa.

O momento histórico do basquetebol brasileiro mostra a falta de metodologia, talvez reflexo da ausência da Escola Nacional de Técnicos de Basquetebol (ENTB), uma tentativa da Confederação Brasileira de Basketball de criar uma padronização dos conteúdos e termos no basquetebol brasileiro. 
Tabela 04 - Conjunto de categorias - conhecimento do jogo

\begin{tabular}{|c|c|c|c|c|c|c|c|c|c|}
\hline Características & $\begin{array}{l}\text { Tot } \begin{array}{l}\text { Tipos de } \\
\text { Sistemas }\end{array} \\
\end{array}$ & Tot $\begin{array}{l}\text { Fund } \\
\text { Téc/Tát. }\end{array}$ & Tot & $\begin{array}{l}\text { O que tem } \\
\text { (Fator Positivo) }\end{array}$ & Tot & $\begin{array}{l}\text { O que falta } \\
\text { (Fator Negativo) }\end{array}$ & Tot & $\begin{array}{l}\text { Momento } \\
\text { Histórico }\end{array}$ & Tot \\
\hline Pressão & 1 & $\begin{array}{l}\text { Rotação } \\
\text { Defensiva }\end{array}$ & 1 & Leitura de Jogo & 4 & $\begin{array}{l}\text { Regra Três } \\
\text { Segundos }\end{array}$ & 1 & Jogo Coletivo & 1 \\
\hline Atleticísmo & 1 & Ajuda & 1 & $\begin{array}{l}\text { Comunicação em } \\
\text { Quadra }\end{array}$ & 2 & Leitura de Jogo & 1 & $\begin{array}{l}\text { Conhecimento } \\
\text { Téc/Tat - Técnico }\end{array}$ & 1 \\
\hline Jogo Conceito & 1 & & & Tecnologia & 2 & Formação & 1 & $\begin{array}{l}\text { Falta de } \\
\text { Metodologia }\end{array}$ & 1 \\
\hline Regras & 1 & & & $\begin{array}{l}\text { Conhecimento do } \\
\text { Téc/Tat - Atleta }\end{array}$ & 2 & $\begin{array}{l}\text { Troca de } \\
\text { Informação }\end{array}$ & 1 & & \\
\hline Jogo Coletivo & 1 & & & Treinamento Cognitivo & 1 & $\begin{array}{l}\text { Aprimoramento } \\
\text { técnico }\end{array}$ & 1 & & \\
\hline Pressão & 1 & & & $\begin{array}{l}\text { Conhecimento do } \\
\text { Téc/Tat - Técnico }\end{array}$ & 2 & Jogo Coletivo & 1 & & \\
\hline Imposição & 1 & & & & & & & & \\
\hline
\end{tabular}

Fonte: Diego Leonardo de Andrade, 2019

Direcionando o informante para a parte final do depoimento, são relacionados todos os assuntos abordados anteriormente, transformando alguns pontos da narrativa em perguntas ou afirmações imanentes complementando com a pergunta o que é essencial, os grupos focais desta pergunta estão expostos na tabela 05.

O atleticísmo é ainda colocado como característica essencial no basquetebol adulto brasileiro atual, o que faz muito sentido, já que diversos testes são feitos durante a temporada, a fim de quantificar a performance física dos atletas, além de valências como envergadura e estatura são levadas em consideração em equipes de alto-rendimento, além do atleticísmo, a pressão também aparece aqui.

O footwork, junto do posicionamento e deslocamento defensivo, aparecem na tabela 11, assim como na tabela 09, porém, a postura do atleta em quadra tem maior número de incidências.

Os técnicos de basquetebol ganham destaque nos fatores positivos do jogo, devido ao aumento do conhecimento técnico-tático dos técnicos, um movimento muito sólido dos profissionais que atuam com o basquetebol adulto, intercâmbios e congressos organizados pela Liga Nacional de Basquete podem ser um fator determinante aqui.

Já nos fatores negativos, nenhum grupo focal ganhou destaque, mas dois pontos chamam a atenção: o primeiro é o jogo conceito, aparecendo pela primeira vez como um fator negativo e o segundo deles é a pressão, não somente relacionada ao sistema defensivo, mas ao fato do jogador defensor pressionar o ataque a todo 0 momento.

O condicionamento físico ganha destaque quando relacionado ao momento histórico do basquetebol, mas outros dois grupos são completamente opostos, um 
coloca o basquetebol em um momento de um jogo individualizado, caracterizado por situações de 1 contra 1 em sua totalidade do jogo e o outro, totalmente o contrário, com o jogo coletivo.

Tabela 05 - Conjunto de categorias - essencial

\begin{tabular}{|c|c|c|c|c|c|c|c|c|c|c|c|}
\hline Características & Tot & $\begin{array}{l}\text { Tipos de } \\
\text { Sistemas }\end{array}$ & Tot & Fund Téc/Tát. & Tot & $\begin{array}{l}\text { O que tem } \\
\text { (Fator Positivo) }\end{array}$ & Tot & $\begin{array}{l}\text { O que falta } \\
\text { (Fator Negativo) }\end{array}$ & Tot & $\begin{array}{l}\text { Momento } \\
\text { Histórico }\end{array}$ & Tot \\
\hline Valores & 1 & Zona & 1 & Footwork & 2 & Leitura de Jogo & 2 & Conduzir o adversário & 1 & $\begin{array}{l}\text { Condicionamen } \\
\text { to Físico }\end{array}$ & 3 \\
\hline Atleticísmo & 2 & & & Posicionamento & 2 & $\begin{array}{l}\text { Conhecimento } \\
\text { Téc/Tat - Técnico }\end{array}$ & 2 & Jogo Conceito & 1 & $\begin{array}{l}\text { Jogo } \\
\text { Individualizado }\end{array}$ & 1 \\
\hline Pressão & 2 & & & $\begin{array}{l}\text { Deslocamento } \\
\text { Defensivo }\end{array}$ & 2 & $\begin{array}{l}\text { Jogo } \\
\text { Individualizado }\end{array}$ & 1 & Pressão & 1 & Jogo Coletivo & 1 \\
\hline \multirow[t]{5}{*}{ Intimidação } & 1 & & & Visão Orientada & 1 & $\begin{array}{l}\text { Conhecimento } \\
\text { Téc/Tát - Atleta }\end{array}$ & 1 & $\begin{array}{l}\text { Treinamento } \\
\text { Psicológico }\end{array}$ & 1 & & \\
\hline & & & & Postura & 3 & Comunicação & 1 & $\begin{array}{l}\text { Desenvolvimento de } \\
\text { Capaci e Habili }\end{array}$ & 1 & & \\
\hline & & & & & & Defesa Motivada & 1 & & & & \\
\hline & & & & & & Intensidade & 1 & & & & \\
\hline & & & & & & $\begin{array}{l}\text { Especialização } \\
\text { Técnica }\end{array}$ & 1 & & & & \\
\hline
\end{tabular}

Fonte: Diego Leonardo de Andrade, 2019

Assim como apresentado nas referências utilizadas no presente trabalho, os sistemas defensivos seguem uma classificação apresentada há décadas, a mesma continua sendo utilizada. A tabela 06 apresenta o resultado da categorização das respostas quando informantes foram questionados se a classificação ainda é válida.

Nesse momento, se faz importante ressaltar que de certa forma, o resultado foi unânime. A classificação pedagógica dos sistemas defensivos é atual, a diferença está nos conteúdos presentes nessas classificações, que com a evolução do esporte, ganharam ramificações.

Visto que a escolha dessa metodologia tem como o objetivo extrair o máximo de informação das narrativas, novas indagações foram feitas aos informantes. Mais uma vez, transformando as falas dos entrevistados em perguntas iminentes.

Como características de uma atualização dos sistemas defensivos e suas subdivisões, o jogo conceito deve ser levado em consideração, sendo que a aplicação dos sistemas defensivos deve levar em consideração a pressão constante no homem da bola.

Curiosamente, o sistema defensivo por zona não é citado na categoria tipos de sistemas defensivos.

As demais categorias não apresentaram nenhum grupo focal que se destacasse em número de aparições, porém, fatores psicológicos se fazem presentes, 
como possíveis itens a serem levados em consideração por serem fatores positivos, negativos e a pressão psicológica estar presente na categoria momento histórico.

Tabela 06 - Conjunto de categorias - Classificação dos sistemas defensivos

\begin{tabular}{|c|c|c|c|c|c|c|c|c|c|c|c|}
\hline Características & Tot & $\begin{array}{l}\text { Tipos de } \\
\text { Sistemas }\end{array}$ & Tot & $\begin{array}{l}\text { Fund } \\
\text { Téc/Tát. }\end{array}$ & Tot & $\begin{array}{l}\text { O que tem (Fator } \\
\text { Positivo) }\end{array}$ & Tot & $\begin{array}{l}\text { O que falta } \\
\text { (Fator Negativo) }\end{array}$ & To1 & $\begin{array}{l}\text { Momento } \\
\text { Histórico }\end{array}$ & Tot \\
\hline Jogo Conceito & 4 & Individual & 3 & Flutuar & 1 & $\begin{array}{l}\text { Conhecimento } \\
\text { Téc/Tat - Atleta }\end{array}$ & 1 & $\begin{array}{l}\text { Treinamento } \\
\text { Psicológico }\end{array}$ & 1 & $\begin{array}{l}\text { Mudança de } \\
\text { Conteúdo }\end{array}$ & 1 \\
\hline $\begin{array}{l}\text { Variações } \\
\text { Defensivas } \\
\text { (Jogadas) }\end{array}$ & 1 & Pressão & 2 & $\begin{array}{l}\text { Direcionamento } \\
\text { Defensivo }\end{array}$ & 1 & Organização tática & 1 & & & $\begin{array}{l}\text { Pressão } \\
\text { Psicológica }\end{array}$ & 1 \\
\hline $\begin{array}{l}\text { Ocupação de } \\
\text { Espaço }\end{array}$ & 1 & Mista & 1 & & & Scout & 1 & & & & \\
\hline Pressão & 2 & & & & & $\begin{array}{l}\text { Conhecimento } \\
\text { Téc/Tat - Técnico }\end{array}$ & 1 & & & & \\
\hline \multirow[t]{2}{*}{$\begin{array}{l}\text { Jogo com mais } \\
\text { contato }\end{array}$} & 1 & & & & & Comunicação & 1 & & & & \\
\hline & & & & & & Pressão Psicológica & 1 & & & & \\
\hline
\end{tabular}

Fonte: Diego Leonardo de Andrade, 2019

Já na tabela 07, há um complemento da narrativa anterior abordando a classificação utilizada dos sistemas defensivos, porém, nesse momento, assim como no anterior, segundo todos os informantes, a classificação é válida, assim como as subdivisões.

Mas, como características dos sistemas defensivos, a abordagem do jogo conceito e universalização das nomenclaturas se fazem necessárias. Quanto aos tipos de sistemas defensivos, todos os quatro grupos são mencionados.

Tabela 07 - Conjunto de categorias - Sugestão de nova classificação

\begin{tabular}{|c|c|c|c|c|c|c|c|c|c|c|c|}
\hline Características & Tot & $\begin{array}{l}\text { Tipos de } \\
\text { Sistemas }\end{array}$ & Tot & $\begin{array}{l}\text { Fund } \\
\text { Téc/Tát. }\end{array}$ & Tot & $\begin{array}{l}\text { O que tem } \\
\text { (Fator Positivo) }\end{array}$ & Tot & $\begin{array}{l}\text { O que falta } \\
\text { (Fator Negativo) }\end{array}$ & Tot & $\begin{array}{l}\text { Momento } \\
\text { Histórico }\end{array}$ & Tot \\
\hline Nomenclaturas & 1 & Individual & 2 & Ajuda & 1 & Jogo Coletivo & 2 & Métodos & 1 & Regra & 1 \\
\hline \multirow[t]{3}{*}{ Jogo Conceito } & 3 & Mista & 1 & Troca & 1 & Scout & 1 & Comunicação & 1 & Estruturação & 1 \\
\hline & & Pressão & 2 & & & $\begin{array}{l}\text { Conhecimento } \\
\text { Téc/Tat - Técnico }\end{array}$ & 1 & & & $\begin{array}{l}\text { Profissionalismo - } \\
\text { Atleta }\end{array}$ & 1 \\
\hline & & Zona & 1 & & & & & & & & \\
\hline
\end{tabular}

Fonte: Diego Leonardo de Andrade, 2019

Já a tabela 08 apresenta a categorização de todas as fases da narrativa, nas 14 narrativas apresentadas, todos os 103 grupos focais alinhados. Para a formatação das categorias, foi considerado somente um grupo focal por fase da narrativa e não a quantidade de vezes que o termo ou a frase que englobe aquele termo foi utilizada pelo informante.

Levando em consideração todas as fases da entrevista, o grupo atleticísmo apareceu 14 vezes na categoria características, mas isso não significa que ele 
apareceu uma vez em cada uma das entrevistas, assim como não significa que não pudesse ser citado em outra categoria, por exemplo, do grupo jogo conceito e jogo coletivo, que aparecem em mais de uma categoria.

Quanto aos dados apresentados na tabela abaixo, o jogo conceito ganha destaque com a incidência de 16 grupos focais, seguido de atleticísmo e pressão, três grupos que apareceram em praticamente todas as tabelas apresentadas, com exceção de jogo conceito, que não apareceu na tabela 11, mas pode-se dizer que como característica da defesa no basquetebol adulto brasileiro, pressão no jogador da bola, jogadores atléticos e o jogo conceito são determinantes.

O sistema defensivo individual é o mais citado e mais presente, seguido do sistema defensivo por zona e o pressão, entende-se que aqui estão falando da pressão como sistema defensivo. Na categoria características, fala-se da pressão como uma atitude da defesa, a não ser que seja passiva ou como técnicos costumam dizer 'a defesa tem que atacar o ataque'.

O footwork ganha destaque na categoria fundamentos técnico-tático e é um item que tem ligação direta com diversos outros itens apresentados aqui, como o deslocamento defensivo, direcionamento defensivo, postura e posicionamento.

O conhecimento técnico-tático dos técnicos levou o jogo a adquirir muitos conteúdos e evoluir, colocado aqui como fundamento por ser relacionado nas entrevistas com a evolução dos fundamentos e totalmente ligado com o que acontece dentro de quadra.

Porém, o rebote é o maior destaque junto com o footwork. O rebote tem ligação direta aos resultados de partidas e volume de jogo apresentado pelas equipes em partidas de basquetebol.

A leitura de jogo é o grupo de maior incidência, quando avaliados os fatores positivos, seguido da comunicação, conhecimento técnico-tático dos técnicos e jogo coletivo. Mais uma categoria onde os grupos focais em destaque podem ter relação, ainda mais atrelando a leitura de jogo com a comunicação e o jogo coletivo.

A leitura de jogo também aparece em destaque quanto aos fatores negativos, são itens que faltam no basquetebol brasileiro masculino adulto. Pode-se dizer que são fatores a serem desenvolvidos. Porém, o maior contato permitido no basquetebol moderno é visto como fator negativo e não a melhorar no basquete.

Seguindo a tendência das características do basquetebol atual, o condicionamento físico tem destaque no momento histórico da modalidade, assim 
como o jogo coletivo. Lembrando que o atleticísmo está relacionado não só às capacidades e habilidades físicas e motoras, mas à estatura e envergadura dos jogadores, em consequência o porte físico dos jogadores, que gera maior contato físico dos jogadores.

Tabela 08 - Conjunto de categorias - Todas as narrativas

\begin{tabular}{|c|c|c|c|c|c|c|c|c|c|c|c|}
\hline Características & Tot & $\begin{array}{l}\text { Tipos de } \\
\text { Sistemas }\end{array}$ & Tot & Fund Téc/Tát. & Tot & $\begin{array}{l}\text { O que tem } \\
\text { (Fator Positivo) }\end{array}$ & Tot & $\begin{array}{l}\text { O que falta } \\
\text { (Fator Negativo) }\end{array}$ & Tot & $\begin{array}{l}\text { Momento } \\
\text { Histórico }\end{array}$ & Tot \\
\hline Atleticísmo & 14 & Individual & 9 & Ajuda & 4 & $\begin{array}{l}\text { Aprimoramento } \\
\text { técnico }\end{array}$ & 1 & $\begin{array}{l}\text { Aprimoramento } \\
\text { técnico }\end{array}$ & 1 & $\begin{array}{l}\text { Condicionamento } \\
\text { Físico }\end{array}$ & 5 \\
\hline $\begin{array}{l}\text { Aumento do } \\
\text { Repertório }\end{array}$ & 1 & Mista & 2 & Antecipação & 1 & $\begin{array}{l}\text { Arremessadores } \\
\text { Eficientes }\end{array}$ & 1 & Comunicação & 1 & $\begin{array}{l}\text { Conhecimento } \\
\text { Téc/Tat - Técnico }\end{array}$ & 1 \\
\hline Jogo Conceito & 16 & Pressão & 4 & $\begin{array}{l}\text { Conhecimento } \\
\text { Téc/Tát - Técnicos }\end{array}$ & 4 & Comunicação & 7 & Jogo Conceito & 1 & Estruturação & 1 \\
\hline $\begin{array}{l}\text { Controle do } \\
\text { Tempo }\end{array}$ & 2 & Zona & 4 & Corta Luz & 1 & $\begin{array}{l}\text { Conhecimento } \\
\text { Téc/Tat - Atleta }\end{array}$ & 4 & $\begin{array}{l}\text { Conduzir o } \\
\text { adversário }\end{array}$ & 1 & $\begin{array}{l}\text { Falta de } \\
\text { Metodologia }\end{array}$ & 1 \\
\hline Defesa Motivada & 1 & & & $\begin{array}{l}\text { Deslocamento } \\
\text { Defensivo }\end{array}$ & 4 & $\begin{array}{l}\text { Conhecimento } \\
\text { Téc/Tat - Técnico }\end{array}$ & 7 & $\begin{array}{l}\text { Conhecimento } \\
\text { Téc/Tat - Atleta }\end{array}$ & 1 & $\begin{array}{l}\text { Instabilidade } \\
\text { Tática }\end{array}$ & 1 \\
\hline $\begin{array}{l}\text { Diminuição de } \\
\text { Espaço }\end{array}$ & 1 & & & $\begin{array}{l}\text { Direcionamento } \\
\text { Defensivo }\end{array}$ & 1 & Defesa Motivada & 1 & $\begin{array}{l}\text { Desenvolvimento } \\
\text { de Capac e Habil }\end{array}$ & 1 & $\begin{array}{l}\text { Jogadores } \\
\text { Universais }\end{array}$ & 1 \\
\hline Disposição & 1 & & & Dobra & 1 & $\begin{array}{l}\text { Especialização } \\
\text { Técnica }\end{array}$ & 1 & Ensinar a Jogar & 1 & Jogo Coletivo & 3 \\
\hline Imposição & 1 & & & Flutuar & 1 & Estruturação & 3 & Formação & 1 & $\begin{array}{l}\text { Jogo } \\
\text { Individualizado }\end{array}$ & 1 \\
\hline Intimidação & 1 & & & Footwork & 5 & Intensidade & 1 & Intensidade & 1 & Jogo Rápido & 1 \\
\hline Jogo Coletivo & 1 & & & Leitura de Jogo & 1 & Investimento & 1 & Jogo Coletivo & 1 & $\begin{array}{l}\text { Maior Contato } \\
\text { Físico }\end{array}$ & 2 \\
\hline $\begin{array}{l}\text { Jogo com mais } \\
\text { contato }\end{array}$ & 1 & & & Posicionamento & 4 & Jogo Coletivo & 7 & Leitura de Jogo & 4 & $\begin{array}{l}\text { Mudança de } \\
\text { Conteúdo }\end{array}$ & 1 \\
\hline $\begin{array}{l}\text { Jogo de } \\
\text { Transição }\end{array}$ & 4 & & & Postura & 3 & $\begin{array}{l}\text { Jogo } \\
\text { Individualizado }\end{array}$ & 3 & Maior Contato & 2 & $\begin{array}{l}\text { Pressão } \\
\text { Psicológica }\end{array}$ & 1 \\
\hline Nomenclaturas & 1 & & & Rebote & 5 & Leitura de Jogo & 10 & Métodos & 1 & $\begin{array}{l}\text { Profissionalismo } \\
\text { - Atleta }\end{array}$ & 1 \\
\hline $\begin{array}{l}\text { Ocupação de } \\
\text { Espaço }\end{array}$ & 4 & & & Rotação Defensiva & 1 & Motivação & 1 & $\begin{array}{l}\text { Ocupação de } \\
\text { Espaço }\end{array}$ & 1 & Qualificação & 1 \\
\hline $\begin{array}{l}\text { Organização } \\
\text { Tática }\end{array}$ & 1 & & & $\begin{array}{l}\text { Treinamento } \\
\text { Psicológico }\end{array}$ & 2 & $\begin{array}{l}\text { Organização } \\
\text { tática }\end{array}$ & 1 & Organização Tática & 1 & Regra & 1 \\
\hline Pressão & 11 & & & Troca & 1 & $\begin{array}{l}\text { Pressão } \\
\text { Psicológica }\end{array}$ & 1 & Pressão & 1 & $\begin{array}{l}\text { Rotação } \\
\text { Defensiva }\end{array}$ & 1 \\
\hline Regras & 1 & & & Visão Orientada & 1 & Scout & 4 & $\begin{array}{l}\text { Pressão } \\
\text { Psicológica }\end{array}$ & 2 & $\begin{array}{l}\text { Treinamento } \\
\text { Psicológico }\end{array}$ & 1 \\
\hline Valores & 1 & & & & & $\begin{array}{l}\text { Sistematização } \\
\text { do Jogo }\end{array}$ & 1 & $\begin{array}{l}\text { Profissionalismo - } \\
\text { Atleta }\end{array}$ & 2 & $\begin{array}{l}\text { Variações } \\
\text { Defensivas }\end{array}$ & 1 \\
\hline \multirow[t]{5}{*}{$\begin{array}{l}\text { Variações } \\
\text { Defensivas } \\
\text { (Jogadas) }\end{array}$} & 1 & & & & & Tecnologia & 2 & $\begin{array}{l}\text { Regra Três } \\
\text { Segundos }\end{array}$ & 1 & & \\
\hline & & & & & & $\begin{array}{l}\text { Tempo de } \\
\text { Reação Menor }\end{array}$ & 1 & Regras brandas & 1 & & \\
\hline & & & & & & $\begin{array}{l}\text { Treinamento } \\
\text { Cognitivo }\end{array}$ & 1 & Técnica/Execução & 1 & & \\
\hline & & & & & & & & $\begin{array}{l}\text { Treinamento } \\
\text { Psicológico }\end{array}$ & 2 & & \\
\hline & & & & & & & & $\begin{array}{l}\text { Troca de } \\
\text { Informação }\end{array}$ & 1 & & \\
\hline
\end{tabular}

Fonte: Desenvolvida pelo próprio autor

Para critério de discussão, a tabela 09 apresenta as estatísticas de todas as temporadas do Novo Basquete Brasil, competição masculina adulta de basquetebol em nível nacional, estes dados foram retirados do site da Liga Nacional de basquetebol e não foi levada em consideração a temporada 2018/19 da competição já que está ainda está em andamento.

Apesar dos informantes falarem da regra, se referindo à questão das faltas, isso pode ser identificado na quantidade de faltas cometidas nas temporadas do Novo 
Basquete Brasil, onde a temporada 2017/18 é a terceira temporada da história da competição com o menor número de faltas cometidas, corroborando assim com afirmações quanto ao jogo mais físico com maior contato permitido pelos árbitros.

A temporada 2012/13 é a temporada com maior número de faltas, porém, foi a temporada com maior número de equipes da história do NBB. Com 18, dividindo o número de faltas por equipe, gera uma média de 792,6 faltas por equipe. Já a temporada $2017 / 18$, tem uma média de 683,6 faltas por equipe, que indica uma diminuição de faltas, por um provável maior contato físico permitido como apontam os entrevistados.

As estatísticas do NBB são apresentadas somente para composição da discussão do trabalho.

Tabela 09 - Estatísticas gerais das temporadas do Novo Basquete Brasil

\begin{tabular}{|c|c|c|c|c|c|c|c|c|c|c|c|c|c|c|c|c|c|}
\hline \multirow[b]{2}{*}{ Temp } & \multicolumn{2}{|c|}{ Pontos } & \multicolumn{3}{|c|}{3 Pontos } & \multicolumn{3}{|c|}{2 Pontos } & \multicolumn{3}{|c|}{$\underline{\text { Lances Livres }}$} & \multicolumn{3}{|c|}{ Rebotes } & \multirow{2}{*}{ Assist } & \multirow{2}{*}{$\begin{array}{l}\text { Bolas } \\
\text { Roub }\end{array}$} & \multirow{2}{*}{ FC } \\
\hline & PTC & PTT & РTC & PTT & $\%$ & PTC & PTT & $\%$ & PTC & PTT & $\%$ & RO & RD & Total & & & \\
\hline $2008 / 09$ & 21222 & 39742 & 3826 & 11029 & 34 & 9532 & 17838 & 53,1 & 7864 & 10875 & 71,9 & 4183 & 10456 & 14639 & 6935 & 3717 & 9924 \\
\hline $2009 / 10$ & 19552 & 36659 & 3835 & 10649 & 35,6 & 9001 & 16789 & 53,4 & 6716 & 9221 & 72,4 & 4120 & 9461 & 13581 & 6234 & 3210 & 8762 \\
\hline $2010 / 11$ & 22406 & 41432 & 3945 & 11380 & 34,3 & 10536 & 19555 & 53,7 & 7925 & 10497 & 75,4 & 4394 & 10918 & 15312 & 6966 & 3648 & 10258 \\
\hline $2011 / 12$ & 22791 & 41320 & 3743 & 10517 & 35,4 & 10555 & 19831 & 53 & 8493 & 10972 & 77,4 & 4177 & 10625 & 14802 & 6843 & 3625 & 10590 \\
\hline $2012 / 13$ & 30680 & 57367 & 5508 & 15308 & 35,4 & 14464 & 27596 & 52,1 & 10708 & 14463 & 74,1 & 6025 & 15189 & 21214 & 9812 & 4923 & 14267 \\
\hline $2013 / 14$ & 27370 & 51301 & 5218 & 14446 & 35,9 & 12446 & 23997 & 51,8 & 9706 & 12858 & 75,4 & 6328 & 15185 & 21513 & 9215 & 5887 & 12854 \\
\hline $2014 / 15$ & 24905 & 46619 & 4679 & 13158 & 35,3 & 11529 & 22075 & 52,2 & 8697 & 11386 & 76,4 & 5859 & 13759 & 19618 & 8823 & 5362 & 11924 \\
\hline $2015 / 16$ & 21804 & 41771 & 4075 & 11908 & 33,7 & 9961 & 19426 & 51,1 & 7768 & 10437 & 74,2 & 5248 & 12781 & 18029 & 7819 & 5022 & 10745 \\
\hline $2016 / 17$ & 22294 & 41964 & 4415 & 13098 & 33,5 & 9684 & 17787 & 50,2 & 8195 & 11079 & 73,8 & 5406 & 13390 & 18796 & 8641 & 3712 & 11202 \\
\hline $2017-18$ & 20596 & 41390 & 4253 & 12899 & 32,7 & 9345 & 18724 & 49,7 & 6998 & 9767 & 71,6 & 5190 & 13457 & 18647 & 6904 & 3627 & 10254 \\
\hline
\end{tabular}

Legendas: Temp - Temporada - PTC Pontos Certos - PTT Pontos Tentados - \% Porcentagem - FC - Faltas Cometidas RD Rebotes defensivos - RO Rebotes ofensivos - Assist Assistências - Bolas Roub Bolas Roubadas

Fonte: Liga Nacional de Basquete (Acesso: Nov. 2018) 


\section{DISCUSSÃO}

O basquetebol evoluiu no decorrer dos anos, basta observar como o jogo teve suas dinâmicas alteradas desde a primeira década de prática até a última. As regras do jogo evoluíram, novas marcações na quadra e critérios foram desenvolvidos, isso influenciou diretamente a ação do jogo.

Em um ponto de vista das regras do esporte, a modalidade evoluiu. As 5 primeiras normas apresentadas na Quadro 01 evoluíram para 8 regras divididas em 50 artigos, conforme já abordado no presente trabalho, assim como o levantamento feito e apresentado na Quadro 02, que pontua grandes alterações da regra que acreditasse terem influenciado diretamente o basquetebol.

Por mais que tenha aparecido pouco nos resultados, a regra é citada como característica, ponto negativo e momento histórico, em todas as aparições, a regra aparece como fator que influencia o jogo devido ao maior contato permitido em partidas realizadas no Brasil.

Com a última atualização das regras, a maior mudança foi a inclusão do passo 0 no Basquetebol FIBA, essa é uma alteração que pode influenciar muito o Basquetebol Brasileiro, já que agora, o atleta pode dar um "terceiro passo", de acordo com a regra, isso remete aos grupos com maior incidência no presente trabalho, o atleticísmo.

Como característica do basquetebol atual, o atleticísmo é o segundo grupo mais citado, porém, se ligada a outros grupos, como defesa motivada e jogo com mais contato, empataria com a primeira característica mais citada, porém, ainda pode-se ligar a outras indiretamente.

Outra característica que pode ter influência da alteração da regra é a pressão, o terceiro item mais citado nessa categoria. Como um dos informantes aponta: "não existe defesa, sem pressão na bola". Com a possibilidade de um passo a mais em progressão para a cesta, existe a possibilidade de mais pressão sobre o jogador em posse da bola.

Ainda falando do atleticísmo, relacionando esse grupo com 0 condicionamento físico que aparece em destaque em momento histórico, pode-se entender que o momento do basquetebol brasileiro é o de melhora do condicionamento físico para suprir a necessidade de sobrepor maiores envergaduras 
e estaturas no esporte atualmente, com aumento de altura dos saltos e velocidade para percorrer maiores distâncias em um menor tempo.

Um relato interessante foi apresentado pelo informante responsável pela narrativa da entrevista 3 . Ele aponta questões relacionadas a às nomenclaturas, tal ponto é um dos motivadores dos informantes quanto se referem ao jogo conceito e ainda pode ser relacionado com outros itens apurados em todas as entrevistas.

Segundo o mesmo informante supracitado, durante sua carreira de atleta, não existiam nomenclaturas ou classificações dos sistemas da forma como é atualmente, mas uma mostra que o jogo evoluiu metodológica e didaticamente. Então, os próprios jogadores criavam esses nomes ou regras para alterações defensivas, o mesmo ponto também aparece no relato feito por outro informante na entrevista 14.

A primeira característica mais citada é o grupo jogo conceito, talvez o mais importante de todos os grupos, pois pode ser relacionado direta ou indiretamente com qualquer um dos grupos. A unidade de registro e contexto jogo conceito, diz respeito a uma maneira de se jogar, baseada em regras para a execução de ações frente a diversas situações, o mesmo também é chamado de jogo aberto ou jogo livre como conta De Rose Jr, Pinto Filho e Correa Neto (2015).

Sendo esse um jogo baseado em regras ou conceitos do jogo, para pautar as ações - no caso, de ações defensivas - se faz necessário, por exemplo, avaliar a forma como a defesa irá conduzir o ataque, fechando meio ou fundo, pressionando mais a bola em determinado setor, flutuando em algum jogador ou após alguma ação ofensiva.

O jogo teve como o primeiro sistema defensivo apresentado, o Individual (Quadro 03), naquele momento, era um sistema defensivo individual simples, não por característica e classificação como atualmente, mas sim, por ser o momento de maturação do basquetebol como modalidade esportiva coletiva.

O último sistema a ser conhecido mundialmente foi o sistema defensivo de pressão, aparecendo em uma partida somente em 1950, conforme apresentado na tabela 03. Curiosamente, são dois sistemas com o maior número de aparições. Porém, é importante salientar que no basquetebol atual não existem sistemas puros, conforme afirmam Paes, Montagner e Ferreira (2009), já que os sistemas utilizam características de outros sistemas em suas formações.

A afirmação dos autores corrobora com as unidades de registro e contexto apresentadas, na categoria característica, a pressão, terceira com o maior número de 
incidências, sendo que o contexto colocado é justamente o de pressionar o ataque, ou pelo menos o jogador com bola, uma característica dos sistemas defensivos pressão.

Um item que aparece na categoria fator que falta, mesmo sendo uma característica, um fator que segundo Farias (2009) foi apresentado pela seleção feminina de basquetebol no Mundial Feminino de 2006, já que brasileiras não apresentavam uma defesa zona agressiva contra arremesso de longa distância, característica apresentada como deficiente nesses sistemas, mas que poderia ser evitada, caso a equipe pressionasse a bola.

Quando observamos a coluna de fundamentos técnicos/táticos o rebote aparece como o fundamento mais citado, o que condiz com a afirmação de Reis (2008), que relaciona o rebote defensivo ao volume de jogo e Pacheco (2009), que relaciona o rebote em regiões próximas à cesta como fundamentais para o contraataque e ao ataque rápido.

Além do rebote, o deslocamento defensivo, posicionamento defensivo e ajuda, além da postura, todos os grupos estão relacionados de certa forma, ao volume de jogo proporcionado pela eficiência defensiva.

Alguns autores, como Okazaki et al (2004) e Meneses, Gois Jr. e Almeida (2016), definem o posicionamento dos atletas de forma clássica, porém, a unidade de registro e conteúdo jogadores universais, apontam o contrário. A ideia de jogadores universais remete à jogadores com um repertório muito variado, podendo assumir diferentes posições e responsabilidades dentro da partida, como aponta o informante 2 ao dizer que o Pivô 5 abre para efetuar arremessos da linha dos três pontos.

O jogador na posição 5 tem a função de pegar rebotes, bloqueios e arremessos de dois pontos. Meneses, Gois Jr. e Almeida (2016), citam também a pouca influência dos pivôs no sistema ofensivo.

Um item que está relacionado ao momento histórico do basquetebol brasileiro que é o conhecimento técnico-tático dos técnicos, que busca intercâmbios esportivos, esse também é um dos esforços da Liga Nacional de Basquete (LNB) e da Associação de Técnicos de Basquetebol (ATBB), como cita o informante 4.

Corroborando as afirmações de Lamas (2006), ao falar sobre os gestos técnicos, o footwork aparece em evidência, nessa categoria, sendo considerado fundamento técnico, já que faz parte da preparação dos atletas no basquetebol atual. 
Junto ao footwork, pode-se incluir outras unidades de registro como o aprimoramento técnico, especialização técnica, conduzir o adversário, intensidade, ocupação de espaço, deslocamento defensivo, direcionamento defensivo e posicionamento. Todos esses podem ser interligados e relacionados como gestos técnicos defensivos sendo levados em consideração na preparação dos atletas.

Um fator ligado a performances de equipes mais eficazes taticamente e por consequência vencedoras é a leitura de jogo. Para que se obtenha sucesso em ações ofensivas ou defensivas, a leitura de jogo é um fator presente e somada à comunicação dos jogadores e o jogo conceito, conforme colocam os informantes $6 \mathrm{e}$ 12 , é ligada ao sucesso de equipes vencedores, merecendo destaque neste trabalho.

Quanto aos fatores negativos a leitura de jogo, comunicação e jogo conceito aparecem, de forma menos expressiva em relação aos fatores negativos, é um indicador que ainda não é unanimidade no basquetebol brasileiro profissional.

Apesar da categoria $O$ que falta (Fator Negativo) ter a maior quantidade de grupos, a incidência entre narrativas foi pequena, no presente trabalho, chama a atenção, a variedade de itens que informantes entendem que estão em falta no basquetebol brasileiro.

O momento histórico da modalidade, o jogo coletivo, aparece em destaque, mas o maior destaque da última categoria é o condicionamento físico, um elo com o atleticísmo, como foi abordado anteriormente.

Como explicado no quadro 06, o atleticísmo está relacionado ao aumento da estatura, força física, envergadura e outras valências físicas dos atletas. Um ponto interessante, pois muitos entendem que o basquetebol atual está em um momento onde diversos chutadores aparecem e existe uma cultura demasiada sob arremessos de três pontos.

No presente trabalho, o grupo Arremessadores Eficientes é o único que pode ser relacionado ao volume de arremessos de três pontos, aparecendo na categoria $O$ que tem (Fator Positivo).

Porém, uma reflexão quanto aos arremessadores pode ser levada em consideração. Da mesma forma como o arremesso do tipo jump, depois de criado, era utilizado para sobrepujar defensores altos, o aumento do número de tentativas de três pontos não seria por conta do aumento da atleticísmo e contato físico, conforme apontado por informantes? 
Outro fator que pode corroborar com essa afirmativa é a ampliação da linhade três pontos, fazendo com que sistemas defensivos se expandam, essa talvez seja uma tentativa da FIBA de afastar jogadores da cesta, dificultando ajudas e coberturas defensivas, já que em sistema defensivo expandido, o defensor tem maior área para defender. Uma ação parecida com a ocorrida em ampliações da área restritiva e alteração de formato, conforme consta na Tabela 04, que também vai de encontro à narrativa feita pelo informante 8 , que diz que o tamanho da quadra está ficando pequeno. Sendo assim, o atleticísmo, um dos fatores determinantes para alterações do basquetebol, já que foi motivo de alterações visuais e até mesmo físicas para a prevenção de lesões e segurança dos atletas.

Uma vez que todos os informantes entendem que a classificação dos sistemas defensivos é atual, uma lacuna aparece quanto a diferença do que é apresentado nas partidas de basquetebol e o que a literatura apresenta como classificação dos sistemas defensivos.

As características dos sistemas defensivos devem ser abordadas de outra forma, pois deveria existir pressão na bola em qualquer sistema defensivo, para maior eficácia da defesa, conforme o informante 11 afirma, refletindo sobre o jogo conceito como os diversos informantes expõem em seus relatos. 


\section{CONSIDERAÇÕES FINAIS E CONCLUSÃO}

Uma série de ações foram necessárias para o desenvolvimento dessa pesquisa, assim, sendo possível finalizar o trabalho dentro do cronograma e prazos estipulados. Porém, algumas limitações foram encontradas no decorrer da pesquisa.

Um problema para o desenvolvimento da pesquisa foi o contato com profissionais. Diversos contatos foram feitos com inúmeros profissionais para que fosse possível atender um número razoável, preenchendo o corpus do trabalho. Muitos contatos foram negados sem motivo aparente ou explicação prévia, mesmo contatos previamente acordados.

A maior limitação foi a escassez de pesquisas científicas voltadas para evolução dos sistemas defensivos ou pesquisas qualitativas em basquetebol, em alguns momentos, uma cruzada para buscar informações sobre a modalidade e até alguns documentos históricos, como os primeiros manuais da modalidade foram necessários.

No basquetebol, é possível encontrar publicações, porém, grande maioria com visão quantitativa e análises baseadas em dados estatísticos de competições, mas poucos objetivam trazer leitura diferente dos dados.

Mesmo com as limitações apresentadas, foi possível dar sequência na pesquisa, cumprindo objetivos propostos e conclusões mostradas a seguir.

O presente estudo, através do levantamento histórico evolução do esporte, buscou identificar a evolução e comportamento da defesa no Basquetebol Brasileiro Masculino Adulto.

Seguindo os objetivos específicos do trabalho, o levantamento histórico da defesa na modalidade foi realizado, sendo assim, possível identificar quais ações coletivas acontecem dentro da modalidade, em ordem cronológica. Dessa forma, o trabalho apresentou interpretação dos motivos da aparição ou criação de cada um dos sistemas defensivos, de acordo com a evolução do jogo e suas regras.

O basquetebol, como modalidade esportiva, evoluiu com o passar dos anos, internacionalizando a modalidade. Ao longo dos anos, foram documentados 4 grandes grupos de sistemas defensivos, classificações pedagógicas, que hoje servem de pilares de defesa no basquetebol, apresentados como classificação dos sistemas defensivos. 
Os sistemas defensivos no basquetebol são classificados em sistemas defensivos individuais por zona, mistos e pressão, sendo que cada um desses grupos têm suas subdivisões, introduzidos no capítulo 3 deste trabalho. No mesmo capítulo, são introduzidos fundamentos defensivos e suas descrições, completando assim, ações defensivas documentadas em livros, artigos científicos e publicações em periódicos, publicações online de circulação em massa.

Historicamente, sistemas defensivos sofrem alterações drásticas, devido à alterações na regra do esporte, que visam em primeiro momento, proteger ações ofensivas e em segundo momento, a manutenção do jogo de basquetebol como fenômeno esportivo-social, a fim de manter o jogo atrativo para o público.

Sendo assim, alterações são feitas visando proteger a eficiência ofensiva, em contrapartida, a defesa se articula a fim de suprimir vantagem adquirida pelo ataque. Com essas alterações, como a entrevista 06 expõe, "a regra protege quem está com a bola".

Os sistemas defensivos também sofrem alterações, de acordo com a preparação das equipes, leitura de jogo e conhecimento técnico-tático do técnico e dos atletas para que possam direcionar adversários a cometerem erros ofensivo, as entrevistas 02 e 10 expressam isso claramente.

Então, um fator determinante para a qualquer mudança no sistema defensivo das equipes é a leitura de jogo, seguido do conhecimento técnico/tático da comissão técnica e dos atletas. Esses três itens se relacionam, sendo um dependente dos outros, já que a ausência de qualquer um dos três leva à ineficiência defensiva da equipe, além do tempo de jogo ou de conclusão de ataque, cronometrado pelo relógio de 24 segundos e placar.

É possível concluir que o basquetebol evoluiu devido ao atleticísmo dos jogadores, levando assim, ao jogo com maior contato físico, uma vez que o espaço de jogo não aumentou, mas o tamanho e valências físicas dos atletas sim, como aponta o narrador da entrevista 09, quando diz que a quadra está ficando pequena.

Os sistemas defensivos do basquetebol se articulam através do jogo conceito, que também, segundo dados levantados, é o mote para a evolução pedagógica do esporte. Conceitos de jogo devem ser introduzidos em maior quantidade, aproveitando assim, leitura de jogo e atleticísmo dos atletas para cumprimento das regras estipuladas em cada sistema. 
Dessa forma, mesmo entendendo que o esporte evoluiu para os entrevistados, a classificação pedagógica apresentada ainda serve, já que o que muda não são divisões, mas sim, subdivisões ou outros itens referentes ao basquetebol, como o próprio atleticísmo e questões relacionadas ao treinamento e preparação física.

Assim sendo, dentro da classificação dos sistemas defensivos apresentada, se faz necessário a atualização dos conteúdos, para que posturas defensivas mais agressivas possam ser abordadas a fim de pressionar o homem da bola e a introdução de conceitos defensivos, para o jogo conceito, como o direcionamento do ataque e outras regras para o jogo através de conceitos. 


\section{REFERÊNCIAS}

ABERNETHY, B; WANN, J; PARKS, S. Treinamento das Habilidades PerceptivoMotoras no Esporte. In: ELLIOT, B; MESTER, J. (Org). Treinamento no Esporte: Aplicando a Ciência no Treinamento. São Paulo: Phorte Editora, 2000. Cap. 1, p. 21 97.

ÁREA RESTRITIVA. Portal de Notícias de Basquete [website]. As Primeiras Regras do Basquete. Disponível em: <http://www.arearestritiva.com.br/as-primeiras-regrasdo-basquete/> Acesso em: 27 jun. 2018.

BARDIN, L. Análise de Conteúdo. Traduzido por: RETO, L. A; PINHEIRO, A. São Paulo: Edições 70, 2016.

BIANCO, M. A. Capacidades Cognitivas nas Modalidades Esportivas Coletivas. In: DE ROSE JR. D. (Org). Modalidades Esportivas Coletivas. Rio de Janeiro: Guanabara Koogan, 2011. Cap. 03, p. 24-38.

BRANDÃO, E; JANEIRA, M; SAMPAIO, J. 6o Campeonato do Mundo de Juniores Masculinos de Basquetebol: Análise do Sucesso Realizada a Partir das Estatísticas do Jogo. Revista Digital, Buenos Aires, Ano 8, n. 45, 2002.

CARVALHO, J; ASSUNÇÃO, L; PINHEIRO, V. A Importância do Treino das Capacidades Coordenativas na Infância. Revista Digital, Buenos Aires, Ano 14, n. 132,2009

CONFEDERAÇÃO BRASILEIRA DE BASKETBALL. Regras Oficiais de Basquetebol. Rio de Janeiro, 1984

CONFEDERAÇÃO BRASILEIRA DE BASKETBALL [website]. A História Oficial do Basquete. Disponível em:

<http://www.cbb.com.br/PortalCBB/OBasquete/HistoriaOficial>. Acesso em: 15 abr 2016. 
CONFEDERAÇÃO BRASILEIRA DE BASKETBALL [website]. Confira as regras oficiais e interpretações FIBA 2017 traduzidas em português. Disponível em <http://www.cbb.com.br/PortalCBB/OBasquete/HistoriaOficial> Acesso em: 28 fev 2018

COMPLEX [website]. The People Behind The Most Mind Blowing Innovations in Sports. Disponível em <https://www.complex.com/sports/2014/03/people-behind-themost-mind-blowing-innovations-in-sports/don-nelson-hack-a-shaq> Acesso em: 18 ago 2018

COOPER, J. M; SIEDENTOP, D. The Theory and Science of Basketball. 2. ed. London: Lea \& Febiger, 1975

DE ROSE JR. D. Análise Estatística de Jogos de Basquetebol: O Fator "Mando de Jogo". Revista Digital, Buenos Aires, Ano 8, n. 49, 2002

DE ROSE JR. D. Modalidades Esportivas Coletivas: O Basquetebol In: DE ROSE, JR. D. (Org). Modalidades Esportivas Coletivas. Rio de Janeiro: Guanabara Koogan, 2011. Cap. 09, p. 113-127.

DE ROSE JR, D. Viva o Basquetebol [website]. Os Primórdios do Basquetebol: A Dinâmica do Jogo. Disponível em:

<https://vivaobasquetebol.blog/2011/11/16/primordios-do-basquetebol-a-dinamicado-jogo/> Acesso em: 18 ago 2018

DE ROSE JR. D; SILVA, T. A. F. Modalidades Esportivas Coletivas (MEC): História e Caracterização In: DE ROSE JR. D. (Org). Modalidades Esportivas Coletivas. Rio de Janeiro: Guanabara Koogan, 2011. Cap. 01, p. 1-13.

DE ROSE JR. D; PINTO FILHO, T; CORREA NETO W. Minibasquetebol na Escola. São Paulo: Ícone, 2015.

DREWETT, J. Basquete: Guia Passo a Passo, Totalmente llustrado. São Paulo: 
Zastras, 2009.

DUARTE, M. Blog do Curioso. A incrível história que determinou o tempo de 24 segundos para arremessos no basquete. Disponível em:

<http://guiadoscuriosos.uol.com.br/blog/2017/08/30/a-incrivel-historia-quedeterminou-o-tempo-de-24-segundos-para-arremessos-no-basquete> Acesso em: 18 ago. 2018

DUARTE, S. M. Basquetebol: Manual de Ensino. São Paulo: Ícone, 2013.

FARIAS, R. R. DEFESA NO BASQUETEBOL: análise sequencial de padrões de jogo relativos ao Campeonato Mundial Feminino de Basquetebol. 2006. 113 p. Dissertação (Mestrado em Educação Física e Desporto) - Universidade de Trás-osMontes e Alto Douro Vila Real, Vila Real, 2009.

FERREIRA, A. E. X; DE ROSE JR. D. Basquetebol Técnicas e Táticas: Uma Abordagem didático-pedagógica. 3. ed. São Paulo: EPU, 2010

FEDERAÇÃO INTERNACIONAL DE BASKETBALL. Official Basketball Rules 2010. Porto Rico: FIBA Central Board, 2010

FEDERAÇÃO INTERNACIONAL DE BASKETBALL. Official Basketball Rules 2014. Espanha: FIBA Central Board, 2014

FEDERAÇÃO INTERNACIONAL DE BASKETBALL. Official Basketball Rules 2018. Suiça: FIBA Central Board, 2018

FEDERAÇÃO INTERNACIONAL DE BASKETBALL. Presentation. Disponível em: <http://www.fiba.com/presentation> Acesso em: 15 abr. 2016

GASKELL, G. Entrevistas Individuais e Grupais In: Pesquisa Qualitativa com Texto, Imagem e Som - Um Manual Prático. Petrópolis: Vozes, 2015. Cap. 04, p. 90-113. 
GONZALEZ, R. H; BALBINOTTI, C. A. A; SALDANHA, R. P. O Rebote no Basquetebol: Estudo Descritivo Exploratório em Jovens Praticantes Brasileiros. Coleção Pesquisa em Educação Física, Vol. 8 n. 1, 2009 ISSN 1981-4313

GUERRA, J. Basquete: Aprendendo a Jogar. Bauru: Idea Editora, 2001.

GUIDE TO COACHING BASKETBALL [Website]. History of Basketball 1922 to 2006. Disponível em: <http://www.guidetocoachingbasketball.com/history.htm> Acesso em: 18 ago. 2018

HARVEY COUNTY HISTORICAL MUSEUM [Website]. Frank Lindley. Disponível em: <http://hchm.org/tag/frank-lindley/> Acesso em: 18 ago. 2018

HARVEY COUNTY VOICES [Website]. "There are Bright Prospects" at Newton High: the Success of Frank Lindley. Disponível em:

<http://harveycountyvoices.blogspot.com/2014/03/there-are-bright-prospects-atnewton.html> Acesso em: 18 ago. 2018

ISNIDARSI, E. M; OLIVEIRA, J. E. C. Preparação Física no Basquetebol. Revista Digital, Buenos Aires, Ano 18, n. 181, 2013

JONES, J. J. The Rise and Fall of Kansas Wesleyan University Basketball. Canadá: XLIBRIS US, 2017

JOVCHELOVITCH, S; BAUER, M. W. Entrevista Narrativa In: Pesquisa Qualitativa com Texto, Imagem e Som: um manual prático. Petrópolis: Vozes, 2015. Cap. 04, p. 90-113.

KURTUS, R. Basketball Players Who Caused Rule Changes. Disponível em: $<$ http://www.school-forchampions.com/sports/basketball_players_who_caused_rule_changes.htm\#.Wkupyl Q-dE5> Acesso em: 21 ago. 2018 
Neuromusculares. Revista Mackenzie de Educação Física e Esporte, São Paulo, Ano 5, n. 1 p. 93-106. 2006

MENESES, L. R; GOIS JR L. E. M; ALMEIDA M. A. Análise do Desempenho do Basquetebol Brasileiro ao Longo de Três Temporadas do Novo Basquete Brasil. Revista Brasileira de Ciências do Esporte, Ano 38, n. 1 p. 93-100, 2016.

OKAZAKI, V. H. A; RODACKI, A. L. F; DEZAN, V. H. OKAZAKI, F. H. A. Diagnóstico da Especificidade Técnica dos jogadores de Basquetebol. Revista Brasileira de Ciência e Movimento, Brasília, v. 12 n. 4 p. 19-24. 2004

OLIVEIRA, J. E. C. Basquetebol: Aspectos Históricos e Funcionais. Revista Digital, Buenos Aires, Ano 17, n. 174, 2012

OLIVEIRA, V; PAES, R. R. Ciência do Basquetebol: Pedagogia e Metodologia da Iniciação à Especialização. Londrina: Midiograf, 2004.

PACHECO, C. Transição Defesa: Ataque no Basquetebol. Zonas de Recuperação da posse de bola, forma e consequência, com diferentes tipos de oposição - estudo descritivo numa equipe sénior CNB1. 2009. 92 p. Monografia (Licenciatura em Desporto e Educação Física), Faculdade de Desporto. Faculdade de Desporto Universidade do Porto, Portugal, 2009.

PAES, R. R, MONTAGNER, P. C, FERREIRA H. B, Pedagogia do Esporte: Iniciação e Treinamento de Basquetebol. Rio de Janeiro: Guanabara Koogan, 2009.

REIS, C. R. Defesa do basquetebol: uma abordagem técnica, tática e de ensinoaprendizagem, Revista Digital, Buenos Aires, Ano 14, n. 132, 2009

REIS, C. P. Ações e Termos Defensivos do Basquetebol. Efdeportes: Revista Digital. Buenos Aires, Ano 13 - Núm 126. Novembro, 2008.

REVERDITO, R. S; SCAGLIA, A. J. Pedagogia do Esporte :Jogos Coletivos de Invasão. São Paulo: Phorte, 2009. 
SANTANA, F. L; ROSTAISER, E; SHERZER, E; UGRINOWITSCH, C; LAMAS, L. Space Protection Dynamics in Basketball: Validation and Application to The Evaluation of Offense-Defense Patterns. Revista Motriz, Rio Claro, v. 21, n. 1, p. 3444, Jan/Mar 2015

SEVERINO, A. J. Metodologia do Trabalho Científico. 23. ed. São Paulo: Cortez. 2007

TANI, G; CORREAA, U. C. Esportes Coletivos: Alguns Desafios Quando Abordados Sob Uma Visão Sistêmica In: DE ROSE JR. D. (Org). Modalidades Esportivas Coletivas. Rio de Janeiro: Guanabara Koogan, 2011. Cap. 02, p. 15-22.

TAVARES, F. J. S. Analisar o Jogo nos Esportes Coletivos para Melhorar a Performance. Uma Necessidade para o Processo de Treino In: DE ROSE JR. D. (Org). Modalidades Esportivas Coletivas. Rio de Janeiro: Guanabara Koogan, 2011. Cap. 05, p. 60-66.

THOMAR, J. R; NELSON, J. K; SILVERMAN, S. J. Métodos de Pesquisa em Atividade Física. Traduzido por: Peterson R. D. S. Porto Alegre: Artimed, 2012.

UNIVERSIDADE DE COIMBRA. Estudo Geral [website]. A História da Modalidade: James Naismith - O Criador do Basquetebol. Universidade de Coimbra. Disponível em:

<https://estudogeral.sib.uc.pt/bitstream/10316/17583/4/Cap\%C3\%ADtulo\%20I\%20\%20Revis\%C3\%A3o\%20da\%20literatura.pdf> Acesso em: 18 ago. 2018

ZOLT H. Hystory of Basketball: Rule Development from the beginning up to now . Disponível em: <http://www.basketref.com/en/index.php/rules/rules-history> Acesso em: 21 ago. 2018 


\section{ANEXO A - ENTREVISTA 01 \\ O Basquetebol no Brasil e a Defesa no Basquetebol Atual?}

Especificamente aqui no Brasil, a defesa individual se desenvolveu muito a partir da chegada de um técnico estrangeiro para dirigir a seleção brasileira adulta, pegamos os conceitos europeus e foram aplicadas na seleção brasileira adulta e replicados nos clubes brasileiros, principalmente depois do que surgiu a Liga Nacional de Basquete, com o NBB. Algumas equipes contam com seus técnicos na seleção brasileira o que facilita muito e hoje podemos dizer que o Brasil é um time que, é um país que possui equipes que defendem de forma muito boa a marcação individual, alguns sistemas mistos e a marcação por zona alguns times defendem muito bem.

Mas a evolução nos últimos 10 ou 15 anos foi muito grande pois veio outro estrangeiro, mas eu acho que se deu quando o primeiro estrangeiro colocou o dedo na ferida.

\section{Conhecimento tático dos jogadores?}

O que aconteceu é que o jogador que marca o homem da bola, passou a ser mais combativo, os jogares ficaram mais físicos, então dificultou muito o trabalho dos grandes jogadores ou dos jogadores que tem mais habilidades, porque as ajudas são muito bem feitas e existem dobras e como não existe aqueles três segundos da NBA a ajuda é até exagerada. A gente larga o último homem, todas as equipes que marcam mais forte o homem da bola largam o último homem da defesa totalmente livre então esse jogador o de ataque tem que ter uma leitura muito boa e um entendimento do jogo muito bom, para acionar de uma forma efetiva, para fazer eficiente esse ataque e para fazer essa bola chegar mais rápido possível nesse último homem ou até no um contra um, mas o que fortalece muito o jogo no Brasil.

Então concluindo as ações defensivas e ofensivas, estão muito mais voltadas ao plano técnico do jogador que tem a bola e o plano tático dos outros quatro jogadores que estão trabalhando.

Os conceitos dos que estão na quadra, normalmente as duas equipes estão desenvolvendo conceitos europeus, que foram implantados aqui no Brasil e que os times estão seguindo muito bem. Paulistano e Flamengo, que são dirigidos por 
técnicos que ficaram 10 anos, 15 anos com a seleção brasileira e tiveram condições de trabalhar isso muito de perto e tem essa vantagem. Mas tem outros times tem bastante times que tem trabalhos diferentes, mas que atingem a mesma situação de boas defesas e ótimos ataques, acho que o desenvolvimento aconteceu nessa europeização do Basquetebol Brasileiro.

\section{Fundamentos Técnicos?}

Sim, uma evolução enorme. Trabalhos como o de 'close out' que é interromper o momento em que o atacante vai fazer o arremesso e hoje é muito treinado. Repetindo a marcação do arremesso né?! O 'close out' com a rotação dos outros jogadores é um trabalho que é muito feito pelas equipes atualmente.

E o trabalho que eu mais gosto de fazer, é um exercício que eu faço quase que diariamente que é o que eu chamo de zig-zag, que é o jogador ofensivo atravessando a quadra em movimentos de mão direita, mão esquerda, crossover, bola entre as pernas, fazendo movimento de troca de direção para o defensor abaixar o quadril manter o corpo em condição de equilíbrio, sem tocar os calcanhares, fazendo o deslocamento de defesa com as pernas bem posicionadas na altura do ombro, sem aproximar os calcanhares, usando os braços né?! De forma que sempre o braço que onde a bola estiver sendo driblada e peito mais próximo a bola bem frente a bola com esse braço mais elevado e são técnicas individuais que tem que ser aperfeiçoadas dia-a-dia, assim como as técnicas as ofensivas, habilidades, passes com uma das mãos, arremesso, os trabalho de pés, mas a defesa tem a primeira rotação e segunda rotação e o trabalho que hoje é muito desenvolvido no Brasil que pouco se fazia que é o do término da defesa, que é o Box out, que é o que a gente chama de selar no rebote de bloquear o jogador que você está marcando, os cinco jogadores tem a obrigação de bloquear o rebote, isso não é uma coisa comum mas que as grandes equipes fazem isso e ficam com uma defesa completa e eu imagino que trabalhando com essas técnicas individuais já há um crescimento enorme na defesa individual.

\section{O que é essencial?}


Continuo achando essencial nos sistemas defensivos, que não é inventar a pólvora e nem é tão moderno assim, é o jogador que marca o homem da bola, saber exatamente que esse é o ponto crucial da defesa, é saber que está marcando um jogador ou um grande armador que distribui grandes assistências então ele tem que conduzir esse jogador para uma posição onde ele não tenha condições de fazer isso, de fazer a marcação fundo, de fazer uma marcação que esconda o do pick and roll que ele deseja, combinar cortes com jogadores mais altos. $O$ jogador que tem a posse da bola eu acho que tem que ter uma orientação muito bem feita e não ser batido em hipótese alguma.

Seria esse o ponto número um na defesa, o jogador que tem a posse de bola não ser batido, não dar a ele a oportunidade de criar e fazer arremessos a cesta e com isso ter toda a contenção e exercícios de troca e um jogador muito forte marcando para que um jogador que tenha a bola, não seja cortado, batido ou tenha um arremesso fácil em sua frente.

\section{Sobre a Classificação dos Sistemas Defensivos}

Totalmente válido, só somente é que a marcação individual é utilizada na maioria das vezes, quase que na totalidade das vezes as outras ficam mais como em situações especiais. A marcação individual ela é a tônica do jogo, é o que vale em um jogo de Basquete, agora você usa uma zona pressão, você usa uma matchup que é a zona mista, você usa a combinada mudando para individual, você usa uma zona pressão como situações específicas do jogo, mas o jogo em si se baseia em situações especiais do jogo, mas o jogo em si se baseia na marcação individual, no 1 contra 1 , 2 contra 2, 3 contra 3, 4 contra 4 e finalmente no 5 contra 5 que é jogado na maior parte do jogo.

\section{Sugestão para uma nova classificação dos sistemas defensivos?}

Nas subdivisões poderia ter o box one, um jogador individual quatro, Diamond, Três individuais e dois em zona e outras subdivisões que se usam em um período mínimo do jogo e logo se volta para a marcação individual. Na marcação Individual o 
grande lance são algumas dobras que se veem jogadores fundamentais da equipe adversária, em movimentos de pic and roll, ajudas mais fortes em um ataque que força muito o jogo interior, ou abre um jogo em quatro abertos para um jogador ter acesso com bastante espaço, em suma a marcação individual é a marcação mais coletiva é mais ou menos como a nossa humanidade, a gente está incluso em uma humanidade de 7 bilhões ou 8 bilhões de pessoas e dependemos uns dos outros, esse movimento acontece dentro da quadra, quando temos 5 jogadores marcando individualmente mas todos dependem uns dos outros para uma super defesa individual 


\section{ANEXO B - ENTREVISTA 02}

\section{Evolução do Basquetebol}

Eu acho que vem evoluindo bastante, eu acho que o Basquete brasileiro passou por uma fase de muita instabilidade principalmente no que diz respeito taticamente, quando a gente fala de defesa mais ainda. Mas a gente sabe que o princípio, que a essência do basquete brasileiro é ofensiva, aliás eu acho que a essência de todo o ser humano é ser ofensiva.

Quando você dá para uma criança, quando você fala para uma criança jogar Basquete, ela nunca fica lá fazendo trabalho de defesa, ela pega a bola e quer arremessar, quer passar de baixo da perna e quer driblar. Então já começa por ai, então eu acho que o principal mesmo nesse período todo ai, foram os técnicos realmente evoluído e terem estudado bastante, terem buscado novas formas de se jogar basquete, lógico não perdendo essa essência do Basquete brasileiro, mas buscando nos estados unidos, na Europa, nos basquetes de mais alto nível para trazer e adaptar, eu vejo muito isso quando eu converso com os demais técnicos eu vejo muito isso, eu vejo todo mundo, sempre que tem a oportunidade indo para fora, participando de cursos vendo vídeos, está fazendo isso e aquilo, então eu vejo que mudou bastante nesse sentido, os técnicos estão ai cada vez se preparando mais, estudando mais e com isso vem melhorando bastante essa situação que eu falei da instabilidade tática-técnica do Basquete brasileiro, então eu vejo que evoluiu muito, mas acho que tem muita coisa para evoluir principalmente no que diz respeito da parte técnica.

\section{Evolução da Defesa}

Eu vejo assim, né!? Por exemplo eu hoje aqui, pratico um tipo de defesa que eu já havia começado a praticar ano passado lá em outra equipe e agora aqui onde atuo atualmente eu venho feito e os princípios são um pouco diferentes do que a maioria usa por aqui. Na NBA tem muito time que utiliza isso, na Europa muitos, que são as primeiras linhas de ajuda, ou jogar o cara para o meio, não jogar ele para a linha de fundo. Então são tantas coisas que se por exemplo se você for voltar lá atrás no Basquete, conversar principalmente com o Professor ' $A$ ' que deve ter 
acompanhado Bastante, técnico 'A', faz isso na época dele de treinador de uma equipe do Rio de Janeiro e outra de São Paulo, ele tinha esse princípio de jogar o cara para o meio e não jogar o cara para o fundo. Mas isso é só um detalhe, um ajuste defensivo que você pode fazer, então como eu falei, não tem a maneira correta ou a maneira isso aqui está errado, isso aqui tá certo. Eu acho que são vários caminhos desde que você tenha conhecimento total e acredite que aquilo ali é a melhor maneira para o seu time defender, aquilo ali vai dar certo, então eu acho que é a questão está muito para a questão técnica da coisa, eu vejo muitos jogadores com muito potencial físico e que você vê e que a cada ano que passa pô esse cara é um dos melhores defensores do Basquetebol brasileiro, mas quando você tem esse cara no dia a dia e trabalha determinadas situações você percebe que falta técnica, falta técnica para executar aquilo ali.

Então não vejo nem tanto das evoluções táticas ou não, mas eu acho que tecnicamente a gente parou de evoluir, a gente está indo muito na questão eu acho que fisicamente obvio evoluiu muito, todas as equipes hoje tem ótimos preparadores físicos os técnicos vem dando cada vez mais espaço para o preparador físico trabalhar então isso tudo vai ajudando também mas eu acho que tecnicamente isso tudo também precisa evoluir para que a gente consiga defender melhor, não só defender como atacar também.

\section{Conhecimento do jogo}

Acho que melhorou, melhorou sim, porque eu acho que o atleta cada vez mais vem se interessando mais, discutindo mais sobre basquete, vem mais basquete, eu acho que os técnicos também evoluíram bastante nesse sentido, então cada vez mais trazem conteúdos novos e também através de vídeo, filmam treino ou filmam uma determinada situação do jogo e mostra para o jogador, então tudo isso, todo esse tipo de coisa ajuda no entendimento do jogador, mas eu continuo achando e volto a dizer que isso ai é responsabilidade minha que trabalho com o adulto e principalmente dos técnicos que trabalham com a base, mas é obvio a gente não pode só responsabilizar eles, só eles lá embaixo, nós também, nós também temos esse dever de chegar, não importa se o cara chegou até mim, não tendo esse conhecimento eu preciso passar esse tipo de conhecimento para ele. Então quando a gente fala assim "o jogador não 
entende do jogo", a culpa é nossa, somos nós treinadores que somos responsáveis por isso. Porque muitas vezes nós fazemos isso, "olha tem que fazer isso. Três contra dois", então o jogador vai lá e faz esse três contra dois, mas para que?! Para que?! Qual o objetivo disso!? O que você tem que fazer?! Qual o objetivo do ataque?! Qual o objetivo da defesa?!

Como você tem que fazer isso? A gente tem o costume, muitas vezes, o que eu vejo muitos, alguns menos outros mais, mas a maioria não explica isso para os jogadores, então ele precisa entender isso, é assim que ele vai entender do jogo, então ele precisa saber o porquê, para então ele fazer "ah, eu faço isso para acontecer isso" "ah, quando acontece isso eu faço isso", e não simplesmente agir por instinto é importante o jogador ter o instinto dele, mas esse é o entendimento do jogo que eu digo, daí é obvio vai ter o treinamento odo cognitivo para ele ter uma resposta motora mais rápido, vai ter o treinamento técnico para ele dentro daquela situação quando for tomar uma decisão ele conseguir tecnicamente sair dela ou resolver o problema, então é uma questão bem complexa ai, mas eu acho que a gente já evoluiu bastante os técnicos vem buscando conhecimento técnico, os técnicos vem ai se ajudando mais, né?! Conversando mais entre nós, eu mesmo faço questão de todo e qualquer treinador que queira assistir um treino meio que venha, eu estou aqui para discutir, porque eu acho que assim que a gente vai evoluir.

\section{Ataque $x$ Defesa}

Mudou, eu tenho um entendimento, eu sempre escutei quando eu joguei basquete "defesa ganha jogo", "defesa ganha campeonato" e tudo mais e a coisa mudou um pouco. Se você pegar alguns números, inclusive do próprio NBB, ia vai de característica para característica, como eu disse o Basquetebol brasileiro é em essência é muito mais ofensivo, principalmente se você comparar com o Basquetebol Argentino e o Europeu, o jogador é muito mais preocupado e por muito tempo a gente valorizou o cara que faz muita cesta, já é assim desde a base, quem é o cara que é destaque!? É o que faz mais cesta, não é o que melhor defende, então se olhar por característica se você pegar, no campeonato argentino nos últimos 10 anos as quatro melhores equipes que defenderam no campeonato, elas garantiram sempre no mínimo semifinal, então se você tivesse entre as quatro primeiras defesas do 
campeonato você vai chegar em uma semifinal, ai tem os números do NBB que mostram o inverso, que se você tiver entre as quatro primeiros ataques do campeonato você está na semifinal, esse ano mudou que o uma outra equipe de São Paulo está na final, mas ai é uma exceção.

Então ai você consegue olhar um pouco e falar assim, bom ai um pouco da cultura do Basquete brasileiro, mas eu acho que a gente precisa mudar um pouco pensando em nível internacional o buraco é mais embaixo.

Só complementando, eu esqueci de comentar um negócio que era muito importante. Até então eu sempre tive isso na minha cabeça, eu sempre gostei e gosto muito de defesa, acho que é importante, acho que é algo muito importante porque vai te dar uma consistência no sentido de não vai te obrigar sempre a ter um aproveitamento muito alto, mas ao mesmo tempo também eu comecei a perceber que essa relação do ataque com a defesa está mais ligada do que a gente imagina então hoje eu tenho uma visão diferente, então é bom você colocar isso nos seus apontamentos, eu falo o seguinte se você ataca bem você defende bem, não é se você defende bem você ataca bem, é o contrário. Se você ataca bem, com espaço, solidário, buscando sempre o cara que está mais livre, buscando sempre a melhor situação ou melhor, nós vamos atacar usando a jogada 1. Mas a jogada 1 é para que?! Então eu falo muito isso para o meu time, nós precisamos entender o porquê nós estamos fazendo cada movimento, não é simplesmente fazer cada movimento e ai você "ah! Eu gosto dessa parte do movimento então eu vou usar ela" não, para que a gente quer com a jogada 1?! Na jogada 1, a gente quer o pick and roll central do 1 para o 5, então vamos fazer a movimentação para chegar ali, é obvio a defesa falhou teve um buraco ali, então vamos aproveitar ali, mas nós precisamos saber disso, então eu falo assim se você ataca com todo mundo sabendo o que a gente está fazendo e as coisas acontecendo, solidário "ah! Agora ele está livre lá, então passa lá" "ajudou no pick and roll porque o Pivô veio no post", todo mundo se sente bem, psicologicamente falando o cara está motivado para ir para a parte que ele menos gosta de fazer, qual a parte que ele menos gosta de fazer, a grande maioria!? (Defender) Então ele estando bem, com o ego inflado, bem mentalmente, o time com energia "porra está legal de jogar", porque é assim, até nós quando vamos jogar na pelada não é legal, quando a bola passa pela mão de todo mundo e o cara faz a cesta, não muito mais legal do que quando um cara pega a bola e fica o tempo todo jogando só ele e arremessa, você pode até ganhar, mas ai você fala, "Pô tá chato de jogar". 
Então eu faço muito essa relação, eu acho que o cara se ele se sente bem, ai volta para a defesa e se eu tiver que me matar para te ajudar porque você foi batido eu vou fazer, eu vou cobrir, eu vou falar e está todo mundo junto, se você ver que um time está cada um chutando a sua bola, você pode perceber que lá atrás, começa a ter o mesmo tipo de atitude e hoje não tem mais a defesa homem-a-homem umcontra-um, hoje não é mais um-contra-um, é cinco-contra-cinco, então se eu vou lá e você está defendendo o Jogador 'A' e ele faz quarenta pontos, a culpa não é sua que marcou o Jogador 'A' e ele fez quarenta pontos a culpa é do time que não te ajudou e não fez o que tinha que fazer para ele não fazer quarenta pontos, não tem mais essa coisa de um-contra-um.

\section{Essencial}

Primeiro fisicamente os jogadores fortes e rápidos e principalmente cada vez você vê mais quando você vai para a Europa ou tem a oportunidade de assistir os jogos de lá, você vê que os caras são enormes e com uma agilidade coordenativa muito grande então é obvio temos que trabalhar com os homens grandes para que eles sejam mais moveis né?! Para que eles possam cada vez mais fazer as ajudas mais rápidas, cobrirem mais espaço em menos tempo, então tudo isso é muito importante, mas eu acho que também tecnicamente, são pequenos detalhes, o cara manter a distância dos pés, não encostar um pé no outro quando tiver fazendo o deslocamento lateral, não abrir demais, não afastar demais as pernas. Então são detalhes e eu estou dando alguns aqui bem simples, clássicos né?! Mas todos esses, não perder o homem de vista, estar sempre entre a bola e o homem, posicionamento defensivo, as vezes o cara está no lugar certo, mas ele está na posição errada, ele está na postura errada, eu vejo muito isso também os jogadores, estão na linha de ajuda, mas como é que eles estão na linha de ajuda?! Todo mundo em pé, a postura de... não está pronto para defender ou para ter que reagir (estalo de dedos 'rapidamente') e correr para o outro lado, então são esses detalhes que a gente precisa evoluir bastante e que eu vejo que na questão de rotações, leitura, ah! Leitura do próprio treinador, ah! A gente vai fazer esse tipo de defesa no Pick and roll, a no bloqueio indireto, vamos fazer isso. Eu vejo que a gente evoluiu bastante, mas eu acho que na forma de execução a gente ainda tem muita coisa para evoluir. 


\section{Classificação dos Sistemas Defensivos}

Eu acredito que ela é válida sim, principalmente para facilitar para o jogador para o entendimento do jogador né?! Mas eu costumo dizer assim como eu já falei em alguma das perguntas, que eu costumo dizer para o jogador que ele tem que defender um jogador e meio, então como você vai defender um jogador e meio em uma defesa homem a homem, ou individual, se você tem a obrigatoriedade de defender um jogador e meio?! Então em algum momento você vai estar defendendo por zona, então assim é válido para ele ou principalmente nas nomenclaturas né?! Vamos defender individual, vamos defender por zona, mas no fim das contas se você for ver a grande maioria dos times não tem mais essa de homem a homem, cada um colado no seu homem, se tomar corte só o pivô. Antigamente tinha isso né?! Ainda era assim, o grandão ficava lá dentro protegendo o aro e cada um marcava o seu homem e se tomasse um corte o grandão ajudava, hoje como o jogo está muito mais variado, os jogadores grandes arremessam de fora ou os jogadores grandes conseguem colocar a bola no chão, larga o Pivô que arremessa de fora na linha dos três e joga lá dentro para você ver o que vai acontecer, então assim, ficou homem a homem com aquela característica de zona, então assim mais porque tudo por uma questão de facilitar o entendimento dos jogadores, mas mudou muito.

Eu não consigo de bate e pronto te responder, eu não consigo ver uma outra maneira que a gente podia classificar, acho que é válida qualquer tipo de classificação desde que ela seja válida para uma equipe, é obvio e é claro que ela teve essa classificações para facilitar, para uma forma onde todo mundo possa pegar um livro e ler e ter defesa individual se classifica por isso, isso e isso, defesa por zona por isso e isso, agora eu acredito sim que com o passar do tempo isso possa mudar e principalmente de treinador para treinador e isso já acontece um pouquinho, um treinador as vezes tem uma determinada forma de chamar algumas situações. A maioria delas vem dos americanos ou da linguagem inglesa. 


\section{ANEXO C - ENTREVISTA 03}

\section{Panorama atual do Basquetebol}

O Basquete atual eu acho que mudou muito com relação a velocidade e força física, uma evolução natural, porque as pessoas ficaram melhores fisicamente né?! E a gente está cada vez mais selecionando atletas puros assim na concepção da palavra, antigamente falando mais da minha geração falando assim, eram poucos jogadores que tinham uma explosão assim, para um lance comum um cara vir e dar uma enterrada por exemplo. Então eu sempre falo isso, nos anos noventa o Brasil tinha um pivô por exemplo que era um cara explosivo nesse sentido. Hoje todos os jogadores tem muita explosão, você pega um time ai com 12 jogadores, 10 são explosivos e podem até por serem mais altos, saltam mais, são mais fortes, então essa evolução física é algo natural e a gente vê isso nitidamente, então o jogo ficou mais físico, mais rápido mais físico, por conta dessa condição física dos atletas então a gente conversando, os mais antigos conversando a gente fala assim 'nossa o jogo hoje está rápido, hoje eu não conseguiria jogar' então você teria que segurar um pouco mais o jogo, teria que jogar um jogo mais armado digamos assim, mas isso é uma evolução natural, para falar de Brasil eu falo de mundo inteiro, eu falo de NBA de FIBA de mundo inteiro, eu acho que a grande mudança é essa e por conta disso a defesa ficou muito mais acirrada com muito mais contato, não que não houvesse contato antes, mas agora um pouco mais. Eu acho que pelo jogo ter ficado um pouco mais dinâmico por conta dessa condição física né?! Antigamente você tinha contato por causa do jogo de 1 contra 1, agora você sabe que o jogador que está ali a três metros, marcando outro jogador ele consegue chegar ali muito mais próximo para pressionar, para ajudar do que chegaria antigamente até por conta dessa condição física então eu acho que basicamente a mudança do jogo é por ai.

\section{Defesa no Brasil}

Bem eu acho que o que evoluiu também são outras situações, mas uma coisa ligada a outra. Como melhorou o jogo físico, o jogo de cada jogador nesse potencial, a defesa teve que evoluir também para poder atingir, para poder segurar esses caras que melhoraram atleticamente. Então a defesa melhorou nesse sentido. Em cima 
disso e por conta disso também o técnico teve que criar mecanismos e eu não falo só dos técnicos brasileiros, mas dos técnicos em geral, eles tiveram que criar mecanismos para cobrir melhor uma possível jogada de um cara que também evoluiu no ataque. Então aí surge tipos de ajuda, ajuda de um lado, a gente não tinha nomenclaturas como as que tem hoje, talvez até tivesse, mas não tinha essas nomenclaturas que temos hoje, ajuda fundo, ajuda, sabe só a pop, etc. Então essa é uma coisa que os técnicos tiveram que criar e os jogadores tiveram que entender isso e isso é um negócio que já se fazem hoje naturalmente e antigamente não era tão natural assim na evolução defensiva que tiveram que cobrir, esse lado que o jogo melhorou, o jogo ficou mais rápido então vamos melhorar também a defesa, vamos criar uma defesa mais rápida para criar essa situação, eu acho que por conta dessa evolução o um contra um por exemplo a gente ainda joga com muito contato, a gente não consegue não marcar fisicamente o ataque ainda continua tendo vantagem nesse sentido e por isso que eu digo que os técnicos tiveram que criar esses mecanismos para tentar cobrir isso, o nosso um contra um a gente ainda tá usando muito braço, porque na perna a gente não tem condição depois do ataque inicia o movimento da gente conseguir recuperar, porque o ataque tem esse lado com o físico superior e o ataque tendo a iniciativa, a defesa ainda está um pouco atrasada e nesse sentido a gente usa muito o braço, muito contato. Aí o jogo fica meio enroscado meio feio.

\section{Conhecimento do jogo.}

Eu acho que mudou sim mudou muito, do entendimento geral do cara saber que o jogo de Basquete é para jogadores inteligentes, sempre foi assim e sempre será e os jogadores cada vez mais estão tendo essa capacidade de entender o jogo, pensando do lado da defesa, o jogador que está defendendo não só defendendo o seu, mas prestando atenção em tudo o que está acontecendo e o que ele pode fazer. Então a evolução nesse sentido é fantástica também o jogador ficou mais inteligente, entende de basquete o QI do jogador está mais apurado e cada vez tem se buscando mais jogadores que tenham isso, que tenham esse $Q$ I avançado para entender mais o jogo, mas o que está acontecendo, mais o dinamismo, mais a força do jogo, os jogadores que tem isso acabam se destacando mais ainda, as vezes até um negócio histórico algo que sempre aconteceu, um jogador que tem esse QI diferenciado de 
entender o jogo, ele acaba superando as vezes uma má condição física, as vezes uma condição não tão atlética do que o time adversário e isso eu acho fundamental nesse evolução constante.

\section{Essencial}

Eu acho que o fundamental é estar fazendo o trabalho de mais de uma pessoa, um trabalho mais coletivo, não só depender da minha ação, mas a minha ação e a ação de um cara que está do meu lado e dos dois pivôs que estão atrás por exemplo, com um time defendendo. Então eu acho que precisa ter esse coletivo muito apurado, então as vezes você tem um jogador que marca muito bem mas ele não tem um coletivo junto com outro, então a gente vai ter equipes que funcionam no 5 melhor do que individualmente, defensivamente falando, então aquele, talvez se você conseguir juntar cinco bons marcadores que se entendam bem você vai ter uma defesa que funcione bem do que simplesmente ter cinco bons defensores, não sei se ficou claro isso ai. Mas nesse sentido isso é fundamental hoje, não adianta ser só um bom marcador, tem que ser um bom marcador conjugado com uma boa defesa. Para que as engrenagens possam funcionar bem

\section{Classificação dos sistemas defensivos}

Acho que é totalmente válida, eu acho que cada vez mais a gente consegue definir isso. Mas eu acho que de um tempo para cá as defesas combinadas passaram a aparecer muitas vezes, as várias defesas combinadas dentro de um mesmo ataque, em um passado recente eles gostavam de fazer muito assim dentro de um mesmo ataque adversário dois tipos de defesa, começa de um jeito e termina de outro jeito de acordo com o que o ataque faz, então isso acaba cada vez mais aparecendo e eu acho que é uma tendência do jogo é uma tendência do jogo, mas a gente sempre vai ter uma defesa individual pura, mas as defesas combinadas acabam aparecendo e sobressaindo, esse lado tático ofensivo está ai com as defesas combinadas acaba aparecendo ainda mais. 


\section{Subdivisões}

Também acho que funcionam do mesmo jeito, mas as coisas você tem que trabalhar muito, eu vejo que cada técnico ou os professores tem que trabalhar muito com o que tem na mão, é aquela estratégia dentro do que você vai fazer naquele jogo especificamente, então você pode ter um jogo que você vai ter que marcar de tudo de uma vez, ou um jogo que você vai marcar individual o jogo inteiro, mas acho que o técnico tem que ter em sua carteira todos os tipos de defesa e isso é o que vai acontecer uma hora ou outra, de você pode precisar usar aquilo lá, então acho que essas defesas vão continuar sim, então de repente vamos ter ainda uma individual pura, uma individual apertando mais um cara, ou deixando a bola voltar para ele, essas variações vão continuar acontecendo sempre.

\section{Sugestão}

Eu acho que vai continuar sendo assim! Não vai mudar muita coisa. As nomenclaturas acabam se tornando comuns, até dos jogadores estarem estudando, dos técnicos trocando informações então algumas coisas acabam padrão, então se você pegar um jogador de qualquer time e colocar em outro e falar, 'vamos fazer a defesa fundo' ele sabe qual que é. Antigamente essa nomenclatura 'Defesa Fundo' não existia era uma defesa que era muito 'olha vou jogar para esse lado você ajuda, vou jogar para aquele lado você ajuda', o que eu quero dizer é isso, a nomenclatura fundo por exemplo é uma coisa que ficou natural, igual você falar em termos de ataque, você falar 'vamos fazer a chifre' todo mundo sabe o que é a chifre, antigamente não tinha isso, não tinha chifre era outro nome, mas isso é algo natural. Na minha época tinha outra jogada que era a pepino, que depois virou flex e os times vão fazendo isso e evoluindo tornando isso algo natural. 


\section{ANEXO D - ENTREVISTA 04}

\section{Basquetebol Atual}

O Basquete de uma forma geral está muito mais físico mais atlético, isso facilita não só o ataque, mas a defesa também. Eu acredito que nós estamos começando a ter uma cultura defensiva, pela própria necessidade eu acho que apertou e acho que começamos a ter um pouco dessa consciência depois que todo mundo começou a jogar de frente para a cesta, como a lugoslávia de 90 em que acaba forçando o cara a ter que se movimentar um pouco mais, então é 1 contra 1 e tudo começou, mas eu ainda acho que falta, que dizer eu acho que estamos de fralda ainda, sabe nesse aspecto. Eu acho que inclusive é própria responsabilidade dos técnicos da Base, ao qual eu me incluo também, existe toda essa discussão, mas ainda não conseguimos chegar em um denominador comum, hoje muito se discute, mas no final a adesão é mínima, fala-se que precisamos ter uma identidade, em alguns estados já estão conseguindo fazer isso.

Mas como nós começamos isso lá atrás, começamos a querer fazer esse jogo mas o Brasil não foi muito adepto, mas todo mundo está caminhando para esse jogo, a defesa começa pelo ataque, é o Basquete Controle, conforme você controla o jogo, só decide com 20 segundos, com 24 segundos, só define no final do tempo, com isso você não deixa a outra equipe contra-atacar, não deixando o time contra-atacar obviamente a sua defesa estará postada, o que ajuda muito, você nunca será pego no contra pé. Hoje o negócio já mudou, as definições da bola, você vê NBA todo mundo, Europa mesmo, o último jogo que eu vi do Barcelona e Real Madrid, pegou a bola parou e chutou, dos três, dos quatro, dos cinco, porque o jogo está muito rápido então já mudou um pouco e a Espanha eu acho, Espanha, Lituânia, os Sérvios eu acho que o povo acha que devemos segui-los, né?! Assim eu acho que a nossa linha deveria ser uma linha mais para a NBA, então está forçando os caras a correr e a correr bastante, mas eu acho que a gente está começando a valorizar a defesa, mesmo que um pouco tardiamente, mais do que valorizávamos antes, porque a gente sempre teve bons atiradores e tal. Então eu acho que houve essa evolução, em uma edição dos jogos olímpicos o técnico ficou doente e eu fiquei junto do outro assistente e o nosso jogo o primeiro jogo, era o jogo que tínhamos que classificar, não tinha um astro, então nós criamos, o assistente na verdade que era um dos responsáveis ficava 
mais na defesa, nós criamos uma defesa com dobras nas laterais e no fundo e que acabou funcionando, os adversários que eram um time muito, um time caribenho, né?! Com uns caras muito rápidos e no um contra um era complicado e tinha o $\mathrm{X}$ e $\circ \mathrm{Y}$, então a gente não podia dar muita chance de rebote, então a gente criou um 1:2:2 meia quadra, com dobra na lateral e dobra no fundo e as vezes ficavam três caras no fundo para fechar o chute e foi onde a gente conseguiu roubar muitas bolas, porque o armador era muito rápido, mas eram variações que só aconteciam em lance livre que a gente já voltava e a gente poupava o nosso melhor arremessador, então ali até o próprio técnico que só acompanhou no final tomou um susto pelo jeito que estávamos marcando e foi muito legal.

Eu acho que hoje tem essa corrente Europeia e Argentina inclusive, um palestrante em uma clínica no interior de São Paulo falou nessa clínica em Bauru, que até os 17 anos, até os 15 anos se eu não me engano a Defesa, não pode ajuda. Minas Gerais faz isso hoje, então por exemplo eles criaram regras e é isso que eu estou falando a associação deles foi lá e disse 'vamos todos trabalhar desse jeito' então a regra é não pode ajudar, até o sub-15 se eu não me engano, então o último homem do lado oposto da bola, não pode sair na bola se ele for batido, eles alegam que isso é para fortalecer o um contra um, mas eu acho que temos outros meios, enfim, para trabalhar um contra um, porque a partir do momento que você prega que o Basquetebol é um esporte coletivo ele deve ser de ajuda constante, mesmo que a maturidade do menino não esteja preparada para isso, então nisso o menino só pode estar com um dos pés dentro do garrafão e o outro tem que estar fora, se ele entrar com os dois pés ele é punido.

Existem algumas outras linhas, como a Americana que eu tenho estudado muito e outras também, mas as discussões sobre a defesa falam primeiro do excesso de jogadas, é primeiro muita gente até os 15 anos pressiona quadra toda, algo que eles são contra, porque acha que não ensina nada porque a pressão psicológica é maior do que a pressão técnica.

Então é eu não sigo muito essa linha aqui no Sub-14 e no Sub-15 e no adulto eu também não sigo, mas o técnico principal é de uma linha meio Popovich de ter todo mundo na linha do passe, mas a gente vê ainda muita gente fazendo bandeja no 'passe e entra' mas ai o lado oposto quase não existe e quem marca em linha de passe não pode pressionar o homem da bola, porque se pressiona e o cara corta não tem cobertura, o técnico da seleção já segue uma linha de ajuda que é a que eu gosto, 
né?! Pressão na bola o tempo todo, fazer o cara retardar um segundo, porque eu acho que isso ajuda a defesa e você pode se aproximar, uma pouco mais atrasado, mas se você for se aproximar com equilíbrio, eu dou meus treinos assim todo mundo do lado oposto tem que ajudar e todo mundo acha que é zona mas não é zona. Porque você ajuda e sai do seu, aí a partir do meio da quadra pressão, eu sou contra em categorias de Base pressão quadra toda, porque se um menino é batido no um contra um na linha dos três você vai colocar pressão quadra toda?! Não funciona, eu acho que você tem que ensinar junto do um contra um todos os deslocamentos e coberturas, partindo do princípio que é um esporte coletivo, porque aí o menino chega lá com 17 anos vai ficar marcando o meio e é isso. Eu falo que a gente quer imitar a NBA, mas nós brasileiros não temos nem a técnica nem a força, em todos os sentidos e a gente quer copiar os Europeus mas não temos a disciplina dos Europeus, nós somos caribenhos também, então a gente tem que criar uma cultura e dentro dessa cultura a defesa, porque a gente só está seguindo a maneira de como os caras atacam, não como os caras defendem, mas nós não temos essa cultura ainda, estamos sendo forçados a criar ela.

\section{Fundamentos Técnicos}

Sem dúvida lógico que evoluíram se não o jogo não tinha evoluído, mas muito em função da força física, hoje nós temos preparadores físicos os caras estão fazendo um ótimo trabalho com categoria adulta. Então essa evolução física, aqui já começamos no Sub-13, os meninos vão uma duas vezes por semana para a

academia para fazer trabalhos de velocidade e deslocamentos sem carga, na Argentina nessa idade os meninos já trabalham com $20 \%$ de carga, hoje os meninos são muito, quer dizer em periferia ainda temos um, mas os meninos são muito internos, ficam muito dentro de casa, aqui a gente brinca muito se o menino sair correndo e tropeçar ele quebra os dentes, porque ele não tem, não existe mais aquele reflexo, não brinca mais na rua, então talvez devêssemos começar com exercícios de coordenação e deslocamento até mais cedo, mas acho que isso tem colaborado muito, eu acho que a parte física está proporcionando nos atletas e nos técnicos, fazendo eles evoluírem mais na defesa. Se pegar o time de Franca de 2016, era um time mais limitado, mas eles chegaram com uma pegada forte para ir para cima e 
como o time do sul fez esse ano, mas esse ano talvez não se veja essa mesma qualidade, porque a qualidade ofensiva faz cabeça do cara, então agora talvez essa geração de hoje, tudo Romário, aquela coisa eu faço ponto então eu não preciso marcar, você pode ver isso no próprio futebol ele evoluiu para caramba, hoje o atacante volta para marcar. No Basquete não tem disso tem ala-pivô, marca muito bem e enterra, mas se sair para marcar o cara em cima é batido em todas, mas também já está com os seus 35, 36 anos. Mas talvez essa geração de hoje, 23, 24 e 25 quando chegar aos trinta e pouco eles vão estar defensivamente mais fortes, é porque como eu te falei, estamos engatinhando, mas a possibilidade de uma evolução grande eu acho que ela é bem latente. Eu acredito muito.

Nós estamos no caminho, apesar que nós estamos no caminho errado por não falarmos todos a mesma língua, mas cada um vai fazer sua opção ofensiva, eu parto da linha que não se deve fazer pick and roll até o sub-15, eu jogo com um motion game com os 5 abertos todo mundo de frente para a cesta jogando livre, eu sempre falo que ensinar jogada é fácil, mas ensinar a jogar é mais difícil, é complicado, mas o 5 abertos vai ensinar o jogador a ter leitura, vai ensinar o jogador a pensar. Eu falo para eles nunca dar as costas para bola, eu falo para eles usarem os braços na direção dos meninos, um braço na bola outro no homem, mas tem menino que o cara passa, e eu falo que ele segura no rabo do outro e dá as costas para a bola e não está nem ai, mas tem uns que aprendem com mais facilidade e outros que não aprendem de forma nenhuma, mas eu paro o tempo todo para fazer eles aprenderem a ler o jogo, tanto na defesa quanto no ataque.

Eu falo que hoje o Basquetebol está duro, porque é um excesso de pick and roll, bate para lá e bate para cá e o pivô lá em cima de bobão correndo de um lado e correndo para o outro para fazer pick and roll e os americanos que jogam no Brasil levam vantagem por serem mais habilidosos, você pega os times que jogam o NBB e até alguns latinos dessas equipes, no um contra um os caras são fudidos. Eu acho que estamos no caminho muito bom, mas eu acho que poderíamos avançar mais rápido. 


\section{Conhecimento dos Atletas}

Acho que hoje os caras tem muito mais recurso, assim os técnicos tem muito mais recurso para treinar e mostrar isso, mas eu ainda acho que alguns decoram, é muito nítido você ver em jogo alguns direcionando os companheiros na volta defensiva pelo menos, mas deveria ser no geral, não simplesmente, em 96 na olímpiada nós íamos jogar contra o Dream Team e a gente foi jogar um amistoso, quando nós fomos jogar na olímpiada e a gente saia no ataque, o armador ia fazer qualquer jogada o primeiro homem da defesa deles já demonstrava a jogada para os caras que estavam atrás, os caras já sabiam todos os movimentos que a gente fazia e eu estou falando isso a 20 ano atrás e nós estamos fazendo isso hoje, é um avanço né?!

Eu acho que sei lá, não sei se chega a $50 \%$, mas essa leitura, tanto para atacar quando, defensivamente eu acho que os jogadores estão mais preparados, mas isso devido o técnico, no NBB tem equipe que fez isso, fez três jogos do mesmo jeito, e três a 0, marcou um 3:2 com os laterais se mexendo muito e fizeram um ataque sem precipitar, com isso tiraram o contra-ataque do adversário que era o carro chefe, que também não pressionou, toda vez que foi pressionar como era linha de passe os caras cortaram para dentro como é linha de passe não tinha ajuda, no ataque não fizeram nada de diferente e a equipe que venceu teve uma leitura do jogo e os 5 caras conversavam o tempo inteiro, então daí você vê que existe uma evolução porque você vê que a estratégia está fazendo parte e antes ela não fazia, na época que eu jogava era 'pega o seu', 'marca o cara', hoje tem recurso, hoje antes do jogo o cara vê, os caras estão editando para você saber o que estão fazendo no ataque, é que na base nós estamos ainda, né?! Eu joguei o High School, 1979-80, 38 anos atrás, eu joguei o High School meu último ano de High School, toda quinta-feira a gente já tinha o filme do time adversário, para saber o que ele fazia e como eles jogavam. Hoje o que a gente faz? Estamos fazendo hoje no Brasil o que faziam lá na década de 70/80.

\section{O que é essencial}

Bom primeiro você acreditar que você só muda a história de um jogo defensivamente, essa é uma ideia que o Pedroca passou para a gente em Franca por isso que Franca faz essa apologia a defesa. Porque você só consegue mudar a história de um jogo defendendo, porque até se você ataca mal, mas se defender bem 
você tem uma maior tranquilidade para atacar, mas se você está naquele jogo onde todo mundo troca figurinha você fala, nossa. Fodeu porque nós estamos uma merca aqui atrás, então até para errar você não tem tranquilidade. Então o Pedroca já falava, você tem que ter pés rápidos e um coração maior que você, eu acho que é isso que nós temos que estar passando como valores para as nossas crianças, eu acho que se a gente conseguir passar isso, porque na minha época e até hoje tem gente que fala, eu nunca vi um time com a melhor defesa ganhar um campeonato, Franca teve muitos, não é a, mas sempre foi uma das melhores defesas do Brasil, então essa ideia de ter um time que só o meu time mete bola já passou, hoje os caras tem a sua importância.

\section{Classificação}

Eu acho que para ensinar, nós trabalharmos com a meninada, são as definições que nós temos e elas são válidas, mas eu me preocupo mais com o conceito, do que com a formação, porque com o conceito você pode colocar qualquer formação e ela pode dar certo, quando eu falo conceito, é 100\%, linha de passe, pressão na bola, os outros mais fechado, em qualquer um dos dois, você pode chegar e trabalhar em qualquer tipo de zona, em qualquer tipo de defesa. Se bem que na mista esse conceito de não deixar a bola voltar ou pressão na bola praticamente não existe. Mas é o conceito da Match Up, Match Up não é Zona, é um trabalho que algumas equipes fazem muito certo, Match Up é um conceito de igualar na bola.

Eu fiz um curso em Boston e lá ele falava que desde o Jump Shot nada de novo acontecer, os fundamentos evoluíram, mas nada de novo surgiu. Lógico é uma metáfora, mas o que evoluiu foi a parte física e a parte técnica, mas em termos de exposição defensiva e agora você vai falar tem as zonas dependendo das características do adversário tem um monte de variações. Mas eu acho que não sai muito dessas defesas aí não. 


\section{ANEXO E - ENTREVISTA 05}

\section{Basquete Brasileiro}

Como que eu vejo o Basquetebol ele era organizado pela Confederação, então era uma parte um pouco mais política. A confederação é política né?! A Liga não, quando entrou a Liga Nacional, que montou o NBB. Ela foi montada pelos clubes. Então já é uma coisa especifica do clube, não é uma coisa política. Eu vejo isso assim, houve um crescimento, não que não fosse organizado antes, era organizado, mas com outra tonalidade no Basquetebol, outra finalidade do Basquetebol.

Mas com a entrada da Liga o Basquetebol virou mais profissional, o Basquetebol Brasileiro ficou mais profissional. Estamos na décima temporada e a cada ano melhora, a cada ano o campeonato fica mais difícil para ser apitado, porque?! Porque os jogos são mais equilibrados, os times melhoram, os times têm mais investimento, você entendeu?! Então assim, em termos profissionais o NBB deu um grande salto qualitativos para o Basquetebol Brasileiro. Em termos de clubes, tanto que se formos analisar as últimas, o Brasil nas ultimas ligas das américas foi campeão com o Pinheiros, Bauru, Flamengo.

A Liga se tornou uma das ligas mais fortes do continente Americano, atrás da NBA só e fazendo frente com a Liga Argentina que tem aí seus 30 anos e nós estamos na décima temporada ainda. Então melhorou muito o nível do Basquetebol Brasileiro, em termos de clubes, de organização, de campeonato, de estrutura. Hoje você pode ver todos os times jogam em uma quadra flutuante, são detalhes que as pessoas podem não dar conta, mas quem está lá no dia-a-dia vê muita diferença.

\section{Evolução}

Eu vejo muito assim é padrão de jogo. Hoje as equipes, quase todas as equipes têm um padrão de jogo, específico daquela equipe, você entendeu?! Antigamente não existia um padrão de jogo, antigamente era mais, eu não sei te explicar, eu sei que é diferente. Hoje você vê que a equipe ela joga em padrão de jogo, um sistema de jogo. Hoje dificilmente você vê aquela correria, aquele peladão que a gente fala, aquele rachão. Hoje não, hoje não, as equipes têm um padrão de jogo, tem um sistema de jogo, fica muito nítido isso para quem está apitando. 


\section{O que vem mudando no Basquetebol ou já mudou?}

Sim vejo, vejo. É como se fosse da água para o vinho. Antigamente eu ia apitar, nos primeiros jogos que eu apitei a 20 anos atrás. Meu Deus, o jogo era uma loucura, uma correria, um peladão, jogando bola pra lá e pra cá e sabe, o cara chega e tipo não comparando claro, a NBA o nível técnico é outro, mas se você vê os jogos da NBA, eu assisto alguns jogos.

O Jogador chega, ele não tem uma jogada trabalhada, se ele está livre ele arremessa e ele não quer nem saber, teve jogos que eu vi ali que eram dois times jogando, era o Houston e não lembro qual o outro time, era o Harden jogando e o do outro time jogando. Era 1 contra 5 e 1 contra 5, não tem um sistema, nenhuma jogada, o cara chegou, pegou, chuta e antigamente no Brasil era assim, hoje não, hoje é mais estruturado, uma jogada mais 5 contra 5, mais um Basquetebol Europeu, mais Basquetebol FIBA e essa é uma diferença muito grande.

\section{Ataque $x$ Defesa}

Evoluiu muito a Defesa, né?! Antigamente, quando eu comecei a apitar o que prevalecia era o ataque, a defesa, usavam muito a defesa, mas não muito trabalhada. Hoje não, hoje a mudança drástica que eu vejo assim no Basquetebol brasileiro é a defesa, antes o jogador brasileiro não sabia defender e não conseguia defender, hoje não, hoje prevalece mais a parte defensiva do jogo.

\section{Classificação Pedagógica}

Essas nomenclaturas praticamente não mudaram, você vê o Basquetebol hoje elas não mudaram. O que acontece é a frequência com que ela é usada no jogo. Assim ó, em um ataque o time tá marcando zona, no outro ataque o time já está marcando match up, outro ataque ele já está marcando mista, em outro ataque eles estão marcando individual. Eles usam muito essas mudanças na defesa, que é justamente para que?! Para você quebrar o ataque. Antigamente no Basquetebol, antigamente vamos marcar zona, aí você passava muito tempo marcando zona, você entendeu?! Depois muito tempo marcando individual, ou muito tempo marcando só um tipo de defesa, hoje não, hoje a mudança do tipo de defesa, ela é igual a uma jogada no ataque, o cara pega a bola e vai atacar, 'ó faz a chifre, faz a um, faz a dois'. 
Agora quando vem defender já vem defesa 1, defesa 2, defesa 3. Porque?! Porque nessa mudança de defesa é quando você confunde o atacante.

\section{Sugestão de uma nova classificação}

Eu acho que assim ó. Em termos pedagógicos, quando você vai ensinar o aluno, ou a criança. Não tem como você colocar muita mudança nisso. Marcação Individual, Marcação Mista, Marcação Pressão, Marcação Por Zona. São nomenclaturas, elas não vão mudar muito para você ensinar, o que muda é a forma como você coloca elas no jogo, é a forma como você ensina o atleta ou ensina para o professor ensinar o atleta dele, é isso que muda muito é como usar elas durante o jogo, eu acho que assim a nomenclatura em si ela não vai interferir no ensinamento, o que vai interferir é assim, é saber como usar e na hora de usar ela, isso que é a interferência maior delas. 


\section{ANEXO F - ENTREVISTA 06}

\section{Basquetebol Atual}

O Basquetebol Brasileiro atual acho que vem em um crescente muito bacana, eu acho que entrada do NBB no Basquete é algo imensurável, eu parei de jogar quando surgiu o NBB e ai se fazem dez anos e era de um jeito agora é de outro. $O$ que me deixa muito feliz e nós estamos falando de adulto, então os técnicos do adulto e eu me classifico nesse meio, estão procurando uma qualificação que eu acho que é fundamental para a evolução do jogo e hoje eu como comentarista e me mantendo atualizado porque eu comentei NCAA e Liga ACB e alguns mundiais então eu tenho contato com alguns técnicos e eu consigo identificar alguns técnicos, não vou falar novos, porque o os técnicos campeões já não são novos, estão ai a algum tempo. Nós estamos discutindo técnicos como os técnicos de algumas equipes do Rio de Janeiro. Para não falar que eu estou focando só nas grandes equipes alguns outros técnicos de equipes que estão retornando agora. Eles estão com uma carga tática é claro cara um com a sua preferência, mas eles têm sim uma carga tática que é impressionante.

A gente consegue observar por exemplo no jogo lá, na semifinal do NBB para falar de um jogo atual, conseguimos ver ação de um técnico reação do outro, ação de um técnico e reação de outro. Isso é estudo, muito e muito estudo, por exemplo eu tenho amizade com um técnico de base, porque eu fui técnico de base, por minha proximidade com um clube que tem equipes de base, sou sócio desse clube e meu filho joga lá então eu tenho muito contato com eles, é um estudo absurdo que esses caras fazem, que só vai ficar defasado quanto a jogo europeu porque o número de pessoas na comissão técnica não é tão grande quanto a das equipes de lá, então aqui o técnico precisa fazer muito mais coisas que o Head Coach lá faz, mas hoje é tudo mastigado. Hoje o cara aqui sabe, por exemplo se o jogador ' $x$ ' cortar para a esquerda ele vai parar e chutar, porque o corte dele para a direita ele vai procurar e o corte dele para a direita, ele vai procurar esse corte porque a eficiência não é tão boa, eu acho isso sensacional, sou apaixonado por isso.

Não tive, eu fiz um ano de técnico no Sub-16, não tive a paciência de galgar meu espaço até ser técnico de um adulto, não é minha personalidade também, mas eu sou muito apaixonado por esse tipo de estudo, da pessoa saber o que a outra faz, ai você dá mais valor ao atleta, porque se você sabe o que eu faço eu vou ter que 
fazer algo diferente, então tenho que treinar mais e evoluir mais, a busca dos técnicos, eu falando de técnicos de adulto que ai tem mais recursos, por clínicas, intercâmbios é imensa. Hoje por conta de redes sociais a gente fica sabendo de tudo, hoje eu vi dois técnicos brasileiros em Murcia. O Campeonato para eles acabou agora e eles já foram atrás de conhecimento. Então isso evolui o jogo, isso evolui o NBB e isso faz com que uma coisa que eu participo diretamente, que a televisão tenha interesse por um bom jogo, a gente tem muitas opiniões contrárias e eu respeito todas, mas tem gente que diz que um jogo que acaba 64 à 61 não pode ser um jogo bom, discordo. Porque se você deixar tal ala livre ele vai matar bola, então se ele não matou bom é porque ele estava muito bem marcado e alguém estudou o jogo da equipe dele, alguém não o técnico adversário estudou o jogo da equipe dele para fazer essa defesa maravilhosa, porque não é fácil você marcar em um jogo onde tem 10 caras que poderiam ser titulares, então tudo é fruto de muito estudo e eu não sei quem vai escutar isso, mas todos eles estão de parabéns, cara. Uns mais outros menos, todo mundo é mais capaz do que o outro, porque um é melhor em uma coisa e o outro em outra e quem não estudar para evoluir vai ficar para trás.

\section{Aspectos defensivos do jogo.}

Cara é assim, primeiro que eu vejo assim. Hoje se o cara não for uma atleta e isso é uma opinião bem pessoal, ele não vai jogar Basquete. Por mais talento que ele tenha porque a defesa vai tirar esse cara da posição que ele quer jogar, aqui eu faço uma alusão até ao futebol, 'pô o cara tem talento, mas o Paulo Henrique Ganso não é atleta ai ele não vai conseguir jogar' e aqui no Brasil, eu tô falando aqui do Brasil o jogo é a cima do aro, quem joga abaixo do aro tem mais dificuldade e começa tudo pela defesa, sem entrar nos sistemas ainda, os aspectos defensivos na verdade o jogo ia até o nome do jogo é bola ao cesto, mas ele tem que começar pela defesa, porque se você marcar bem você não vai dar tempo da outra defesa se armar porque você vai jogar sempre em transição, chegando em vantagem com a outra defesa ainda desarrumada ou o grande no pequeno e o pequeno no grande e daí você começa as suas movimentações ofensivas. Particularmente se eu sou um Coach eu vou começar meu time pela defesa. Mas porque você não quer ataque, mas a defesa vai facilitar demais o meu ataque, começaria por aí. Eu acho que primeiro tem que ser um atleta 
porque tem que ter perna e hoje o atleta tem que estar preparado para jogar, estou falando do grande craque que vai jogar entre 28 e 29 minutos e acho que 15 minutos é o tempo que o cara vai te render uma defesa forte, para poder roubar atrás e poder atacar, porque se atacar rápido eu não preciso só do chutador, eu vou fazer tanto a bandeja ou chutar bolas livres que o time bem treinado vai matar. Então isso é um aspecto que eu penso e não é fácil você fazer um time fazer isso. Eu falando fica tudo fácil, eu comentando o jogo parece muito fácil. Mas estando lá para treinar ou ao menos para executar eu sei que é muito difícil.

\section{Fundamentos técnicos}

Evoluíram muito, você vê que hoje uma das coisas que quase todo o aquecimento que eu vejo até na base não só no alto rendimento, todos tem footwork, hoje você não vê mais as pessoas com, bem técnico isso mesmo, você não vê mais ninguém com o calcanhar no chão. Todo mundo com a ponta do pé, porque!? Porque na ponta do pé você vai estar veloz já para a explosão, é muita explosão, é muito cansativo, isso eu acho que é um dos princípios básicos, o cara está com o calcanhar plantado no chão ele está mais lento, ele está tentando descansar, é raro principalmente nesses times que chegam, dos oito que chegaram, jogador de pé na quadra, não tem mais um jogador que fica em pé na quadra, do lado contrário que chega.

Isso tudo é fundamento, isso daí é leitura, a gente fala muito de leitura ofensiva, a defesa tem que ter leitura do homem que vai, quando esse homem cortou se eu estou em uma boa posição para levar um foul de ataque, acho que tudo é uma evolução dos fundamentos e como eu disse isso não é fácil, mas no Basquete também vai pagando os maiores salários você vai pegando os melhores jogadores que possam se adaptar aquilo que você quer, então é uma evolução monstruosa e dos fundamentos também né?!

De footwork, de exercícios defensivos de treino de 1 contra 1, 2 contra 2 e 3 contra 3, desvantagem na defesa, dois conta 1, três contra dois e muita muito e uma coisa também que eu acredito é que o técnico não consegue chegar nisso em uma única temporada, eu acho que para o técnico chegar onde ele quer, é o caso do alguns técnicos que estão à frente de equipes finalistas do NBB, não é por acaso que esses 
caras que chegam, continuidade de trabalho, você vê o time troca, mas a espinha dorsal do time é sempre a mesma e eu já falei isso para outro técnico, daqui a pouco a sua equipe bate campeã assim como outras equipes tem grandes chances de ser campeãs, porque eles vão chegando, uma hora bate campeã.

\section{Conhecimento do Jogo.}

Nós estamos falando de adulto masculino, é um jogo de alto nível. Eu lembro, vamos falar de mim quando era jogador. Eu tinha um técnico que falava quando eu pegava a bola, ele só corta para a direita e eu não eu corto para cá porque o seu cara não está marcando e é mais fácil para mim aí o cara fechava e eu ia para a esquerda, então também tem essa evolução onde a defesa sabe. Eu tinha comentado do Jogador ' $x$ ' porque é um caso bem especifico, isso ninguém falou, isso eu observei. Ele põe, ele tenta o corte ai ele tenta o chute e não sai com a mesma eficiência e é um cara extremamente eficiente, se você não tiver isso na sua mente você vai tomar um monte de chute dele batendo para esquerda, porque ele vai parar e chutar e se você prestar atenção nesse jogador em específico e se ele for para a direita ele vai procurar o corte ou o chute não sai tão eficiente.

Mas o ataque sempre vai levar vantagem, principalmente se ele tiver no 1 contra 1, porque ele tem a ação e a defesa a reação. Lógico que quando eu fui técnico um ano eu falava você faz a ação, mas é difícil o cara faz a ação, ele tem a bola e a regra protege quem está com a bola, até que alguém me prove o contrário, eu estou com a bola não posso ser tocado, então para a defesa então é sempre muito difícil e essa evolução e por exemplo se eu estivesse no NBB estudando, eu iria estudar o Jogador ' $Y$ ', mas como se marca um bicho desse?! Mas a defesa (Bate socando a mão gesto) como marcar o Jogador ' $z$ ', como você marca esses caras, mas tem técnico que achou um jeito e ai não é 1 contra 1, entra todo um sistema, no 1 contra 1 é difícil parar o Jogador ' $y$ ', mas se você tem um sistema que vai fazer o Jogador ' $y$ ' fazer algo diferente do que ele está acostumado, quer dizer que tem um sistema que vai fazer o Jogador ' $y$ ' passar para o outro lado da quadra, para fazer a defesa ter tempo de chegar, não pode nunca ser o lado da bola, esse tipo de coisa.

Eu acho que esse estudo, essa é a evolução que os técnicos tiveram, quando eu jogava a ajuda já não vinha do lado da bola, era sempre do lado contrário, mas 
isso é de técnico para técnico como você está pedindo a minha opinião eu falo como quando estou comentando, o meu microfone está na minha mão eu vou falar o que eu acho, então talvez as pessoas não concordem, mas como é minha opinião se eu fosse o técnico hoje eu usaria a ajuda sempre do lado contrário porque hoje no alto nível se eu ajudar do mesmo lado eu passo e faço, o cara com meio metro, o diversos jogadores hoje vão matar bola.

Você precisa ter um sistema muito estruturado algo muito bem elaborado, muita rotação e é por isso que eu sempre digo 'no um-contra-um é muito difícil de você marcar, mas você tem que trabalhar o máximo possível para dar tempo da ajuda chegar' se ele te cortar, fizer uma finta e cortar em uma linha reta não tem sistema que vá dar certo, eu falo do giro de mudança de direção e a defesa consegue chegar e você consegue atrapalhar e tem equipe que conseguiu fazer isso, tirou da zona de conforto, teve que fazer eles fazerem algo que não fizeram todo o campeonato e aí você mexe e tem que fazer um time que tinha 80 pouco diminuir para 60 e pouco e a sua produção acaba sendo maior e você ganha confiança com isso, você se sente mais confiante e isso repercute no ataque.

$\mathrm{Na}$ minha época você se sentia muito confiante quando você matava duas bolas, você matava duas bolas e o jogo era teu, mas você não tinha tanta obrigação de defesa e eu era um cara que gostava de tentar intimidar, então fundo bola, eu ia apertar o armador no começo do jogo então se ele desse um drible e tentasse passar e desse a bola para o ala levar eu já falava 'ganhei' ele não está me enfrentando é uma imposição minha na defesa, então eu já falava 'tô grande' é uma coisa muito, lógico que se eu fosse jogar contra o armadores que eu conhecia melhor o jogo, com nível de seleção é lógico que eu não ia fazer isso porque os caras iam me enfrentar, mas sabe os caras que eu achava que eram do meu nível tem um respeito mútuo aqui mas tinha outros caras que eu já não deixava nem crescer, se o cara desse um drible e não me enfrentasse para levar a bola, eu já falava 'ganhei o duelo', então tem muito da imposição, tem muito do técnico e tem muito do sistema, acho que muito do jogador querer fazer o cara vir fazendo um zig-zag você está cansando o cara. 


\section{Essencial}

O Estudo. O Estudo. Tudo eu acho assim, o esporte para mim é um jogo de paciência, quem não acreditou nisso ficou. O técnico que não acreditou nisso ficou para trás, hoje se você não tiver uma equipe que vai te mandar os pedaços, você vai mandar no WhatsApp do cara 'o olha aqui', o Danilo vai enfrentar o técnico ' $x$ ', 'Danilo tá aqui os lances do técnico ' $x$ ' essa bola eu não quero, se ele dizer algo diferente disso, Okay.

Mas essa bola ele não pode fazer porque eu estou te mostrando isso, você vai fechar a jogada um começa assim, ela é para começar aqui e terminar lá embaixo. É lógico que tem toda uma preparação, aquilo do calcanhar, mas isso vem da base. Mas se você não estudar, então você tem que ter um preparador físico o cara tem que ter um abdome forte, o core que está tão na moda, então se você não estudar para dar arma para o cara, não tem como cobrar, porque cada um querendo sair de um jeito. Eu gosto muito quando eu vejo o técnico tentando mudar defesa, então isso eu vejo muito pouco, porque eu também não acredito nessa defesa. Bloqueio o armador que mata bola, passa por de trás do bloqueio eu acho que é uma vadiagem porque se o armador é bom ele vai armar, pode até chutar mas tem que estar pensando, agora ele manda ajuda dar o Step e volta, não deu certo e o cara conseguiu achar o pivô ele conseguiu, ele manda dobrar isso me mostra que o time está treinado, técnicos que mudam no meio fazem a leitura 'Oh comecei assim não deu certo, porque o cara achou uma saída' então ele muda, então eu acho que de tudo, você pode ver nós estamos colocando a parte de treinamento, mas too mundo treina, mas se você não estudar você não vai saber fazer, você não vai saber passar e aí você vai se complicar, você não estudou e ai como é que eu saio você está querendo uma coisa e pensando em outra o time de Basquetebol é um relógio. Isso desde todos os tempos, era mais tempo hoje é mais rápido é um relógio. Combinou você não fez aí só tem uma saída você precisa trocar, você vai perder o jogo não vai chegar onde você quer.

\section{Fundamentos técnicos Individuais}

Até mais que fundamento, não sei nem se essa é sua pergunta, que seria perna flexionada, deslocamento lateral, tudo é importante. Mas estamos falando de Basquete Brasileiro, não de NBA e de Europa que eu acho que o nível ainda está mais 
lá em cima. O cara que tem uma boa leitura defensiva ele sai na frente, que as vezes esse cara, ele não corre tanto, então aqui o Basquete Brasileiro ainda suporta, ele tem que ser um atleta, as vezes você vê pessoas que não correm tanto, correm que são rápidos mas que não corre tanto, eu vejo o Jogador ' $Y$ ' ele tem os atalhos dele, eu não vou falar que ele vai marcar igual ao Jimmy e eu nem cobraria que ele marcasse igual a outros marcadores, ele é o Jogador ' $Y$ ' eu preciso que ele também me de ponto, mas ele tem a leitura, eu não vi quem que ele marcava mas eu não vi, o Flamengo 'explorar o jogador que o Jogador ' $Y$ ' está marcando no ataque', você não escutou isso porque é um cara que tem uma boa defesa, não tem mais a velocidade outros tempos, não é o marcador do meu time, com certeza não tem mais aquele deslocamento que o marcador tem, mas que com certeza ele já teve por ser um americano, mas ele tem uma leitura que deixa ele tão bom quanto, você não vai por ele para marcar o melhor jogador do time, porque seria um absurdo, mas ele não vai te comprometer, as vezes eu gasto o melhor defensor que é o meu melhor jogador e ponho o meu pior defensor em um cara mais ou menos e o cara mais ou menos faz 16 pontos, então quebrou, não sei se você está me entendendo. Mas não acontece isso. Nem com os outros jogadores de outras equipes, que são os caras que sabidamente são ofensivos, né?!

Então o deslocamento lateral a preparação física, o braço aberto isso tudo seriam os fundamentos da defesa que talvez tivesse que explicar, mas a leitura de jogo você dá um atalho nisso, o cara vai cortar e vê o Pivô 'x' que é um baita defensor que tem um baita de um posicionamento no meio do Garrafão e eu não corto, as vezes não é nem o meu homem que me parou, eu vou parar porque o cara está lá e isso nem o scout marca você tem que ter um olho para isso e o cara não cortou porque ele está lá, tem um cara de 2.08 m lá me esperando e eu vou ter que parar e dar o chute, não é que eu não passo eu passo, mas ali tá foda isso tem um valor e isso é leitura, lógico que tem um treinamento mas isso é leitura de jogo, leitura de quem você está marcando, de quem está tentando, para quem eu vou ajudar. Mas se estivermos falando de fundamentos individuais, lógico acho que a perna flexionada, um ótimo deslocamento lateral, hoje quando você está scouteando alguém você vê esses deslocamentos, frente costas lateral, os braços abertos e o cara que fala na defesa, principalmente se ele for o pivô. Não sei até onde você jogou, mas quando eu jogava tinha um cara que era o Gema 'cobre aqui' 'o passou' 'vai lá' isso tudo também não 
aparece no Scouting só que meu, 'bloqueio, bloqueio', essa comunicação é que quando acontece, não pode ser mudo, defesa muda time morto.

\section{Classificação Clássica}

Vale, embora no adulto profissional, como estamos falando do Brasil, a defesa pressão é muito raro de a gente ver, ainda mais do cara de um nível, então ele quando está no ataque ele vai jogar uma bola para fora, não sei o quanto eles treinam. Mas hoje se tem caras muito qualificados para sair com a bola, então você tem pouca pressão. Eu particularmente gosto de pressão individual quadra inteira, mas o armador já que alguns técnicos fazem, mas se você tem um time muito velho você já não consegue fazer, como esses técnicos fazem, mas a equipe com a melhor defesa do campeonato, marca $3 / 4$ de quadra. Eu comento o jogo e fico caramba, o cara protege a casinha dele, o técnico 'a' que já tem a molecada, coloca o cara para buscar lá no fundo bola e é um desgaste, o passe chega mastigado.

Então são estilos de jogos e jogo diferente que avaliando o seu elenco você faz, uma defesa por zona é válida, mas a defesa tem que estar pressionada para mim, não existe mais aquele 2:3 avião a bola tem que ter uma pressão na bola, mas também não vou pedir para ninguém marcar a 2:3 de Syracuse que eu estudo aquilo e não consigo entender aquilo, tem uma dobra no canto da quadra e de repente o cara do meio está lá. Mas inventaram agora uma defesa 1:4 ou 4:1 não sei se você viu essa, não parei ainda para estudar porque não apareceu ainda por aqui, mas é uma defesa meio em diagonal e como ataca aquilo?

Mas apareceu essa defesa, são vários tipos de defesa, 1:3:1 que hoje você já não vê usar mais, mas a 1:3:1 com os caras dobrando nos cantos eu gosto, 1:1:3 que a bola vai ter um cara lá gosto, mas gosto das defesas por zona também não tenho nada contra você ensinar, mas assim as defesas pressão $3 / 4$ de quadra e meia quadra hoje no adulto até que você vê muito pouco são umas situações que são muito de desespero, muito específica, então eu não acredito que se perca muito tempo com isso, mas individual e com rotações e as defesas por zona eu acho que você tem que ter pelo menos umas três defesas por zona para variar. 


\section{Sugestões nas subdivisões}

Vai ter alterações, vai ter que alterar. Até porque essa regra do passo zero, vai ter que alterar, acho que os jogadores ainda estão antigos, mas quem ainda vem vindo, vai vir mas se eu falar três passos vão ficar loucos, mas os vídeos que eu tenho recebido da FIBA basicamente são três passos, o cara começa com o pé direito e pode terminar com o direito, direito, esquerdo direito. Jogadores grandes e fortes com o Eurostep que hoje todo mundo, vai ser muito difícil de você defender é claro, o ataque vai ter uma vantagem e a defesa vai ter que arrumar um jeito de defender, vão aparecer outras subdivisões. Danilo, eu gosto de evitar corte pelo meio, eu ajudo a defesa para evitar corte pelo meio e arrumar quando o corte for para o fundo até porque as linhas são defensores.

Quando você recebe a bola ou você vai para o meio ou você vai para o lado e é muito difícil quando a gente está falando de alto nível mas se o seu time tiver $5 \mathrm{e}$ porque eu gosto disso, eu joguei por muito tempo e a pior coisa que tem é quando você toma uma cesta e eu acho que é você e você acha que sou eu, mas quando você tem um sistema você olha e 'quem era que tinha que estar ali, eu?! Então foi você' se não fica uma discussão que a 'foi você, foi eu', mas ninguém vai acertar, quando foi ali todo mundo vai saber quem é que tinha que estar lá. Eu gosto de regras, respeito quem dá o meio, respeito quem não dá lado nenhum, respeito quem troca, gosto de troca, quem disse que armador não marca pivô. É aquela eu vi o armador tomando frente do pivô e a bola não chegando no pivô e a bola não chegando lá não, desde que o pivô aperte, isso é treino desde que o pivô esteja apertando o cara que vai passar a bola e tenha outra ajuda, então eu gosto, gosto muito troca, troca! Mas qual a característica do time, é ter o armador que vai tomar a frente do pivô adversário e o meu pivô vai apertar, troca tudo é o armador que vai ficar com o pivô em baixo, pode trocar o meu armador segura o pivô adversário e o meu pivô segura o armador tranquilamente, isso depende muito do que você tem mas deve aparecer coisas novas como apareceu essa 4:1 em diagonal com 1 atrás eu olhei e 'que que é isso' né!?

Deve demorar para aparecer por aqui, nós ainda somos arredios aquilo que a gente não domina mas eu acredito que até no individual deve aparecer muita coisa, é 
capaz de você ver dois jogadores marcando um, é que dois as vezes tentar diminuir o domínio do arremesso, um fica livre, tem um match up, box 2, box 1 mas existe né?! $E$ vai do técnico e quando você fala do alto nível profissional algumas coisas nós não vemos mas elas existem uma vez eu vi alguém marcar o triangulo invertido, é difícil mas se você treinar tudo é possível ai você vai colocar dois embaixo e é possível, tudo é válido, não descarto nada, estou aberto a aprender tudo, depois eu falo o que serve e o que não serve para mim, mas isso tudo depende muito do material que eu tenho na mão. 


\section{ANEXO G - ENTREVISTA 07}

\section{Começar falando da sua visão dos sistemas defensivos e formas geral.}

Eu acho que evoluiu hoje. A gente já marcava zona, a gente já marcava zona, a gente já marcava Match Up que era a individual com zona combinado, a gente já marcava isso em 1970 eu lembro já marcava individual pressionando quadra toda seleção de Cuba em 1973 Panamericano fez isso, já marcava.

O que mudou foi os conceitos das dentro das próprias sistemas defensivos, então por exemplo bloqueio na bola que é o Pick-and-roll e o Pick-and-Pop, então começou a ter três, quatro, cinco ou seis tipos de defesas, para esse tipo de situação, o bloqueio indireto, poste baixo, entrada do posto, flash que era a triangulação, então dentro dessas evoluções na parte ofensiva começou a ter respostas de conceito cada situação, é o que basicamente hoje treina. A gente no início como técnico a gente treina a jogadinha do adversário, hoje em dia a gente não treina mais, a gente treina situações das jogadas que eles vão fazer, né?! Então exemplo, uma jogada de bloqueio pick-and-roll na cabeça, então eles têm a jogadinha 2 que foi rodou, mas que vai definir ali, é nossa defesa aquele conceito. Aí nós temos os tipos de rotação para o tipo de atitude que vai ter. Então essa foi a grande mudança no sistema não, não nas nomenclaturas, mas nos conceitos de cada defesa.

\section{Evolução do Jogo.}

Evoluiu muito porque entrou muita parte física, aí o que eles tiveram que fazer?! Abrir espaço, o 4 que jogava dois pivôs. O quatro ele abre e o que passou ser um ala forte e mais um cinco que está abrindo e acabando 5 Center interno, qualquer um pode fazer a função do cinco, qualquer um pode fazer a função do 4 , do três e do dois. O que tá um pouco difícil ainda fazer a função do um que o cara que organiza um pouco né?! Mas já logo-logo também vai acabar essa organização e vai passar jogar só em conceitos, então o que hoje a regra conceitual de sistema em qualquer Shuffle, Flex, Espaço é dar espaço e jogar sem a bola, jogar com a bola, é ser objetivo e usar o que o adversário tem de desvantagem, você usar um jogador mais alto no mismatch, num jogador que não marca tanto jogar contra ele um contra um e por aí vai, vai trabalhando. 


\section{Essencial}

Eu acho que é a dificuldades com tantas opções defensivo estratégias, acho que partiu para a parte mental agora, o foco, o comprometimento, a superação, coisas que existiam lá atrás, garra só que de uma forma organizada e funções mais de uma, duas, três, quatro funções, então acho que isso ai que é o grande, hoje é a parte mental o jogador ser competitivo e estar trabalhando para evoluir aos 37 anos de idade colocar mais coisas no jogo dele por ele estar sendo exigido ou fazer uma mudança alimentar e melhorar o físico ou melhorar isso sempre tem alguma coisa você tem que dar uma mudança.

\section{Classificação Clássica}

Não ele é válida, ela continua o que mudou foi o conteúdo dela, os conceitos as rotações, em função de abrir de jogador fazer várias funções, do cinco abrir para chutar não fazer só bloqueio e entrar para chutar, ele abrir para chute rotação do lado do oposto. Então dentro dessas classificações não tem uma nomenclatura nova de sistema, mas tem uma mudança de conteúdo dos conceitos. 


\section{ANEXO H - ENTREVISTA 08}

\section{Carreira}

Bom, eu joguei como federado dos 15 aos quarenta anos. Comecei na equipe infantil lá em Franca e nesses 25 anos eu joguei, 4 anos em Uberlândia, 3 anos no Vasco e todos os outros anos eu joguei por Franca, tive oportunidades de disputar campeonatos Paulista, mineiro, brasileiro, sul-americano, Pan-americanos e para te falar bem a verdade eu tive a grande felicidade de ganhar todos esses tipos de campeonatos. Só o mundial que nós fomos para a final contra o San Antonio Spurs, com o Vasco e acabamos não ganhando.

Mas eu, independente de título ou qualquer outra coisa, eu acho que o mais interessante é o conhecimento, é o que o Basquete te dá em termo de relacionamento, de conhecimento é o quanto você cresce conhecendo pessoas e o meu pai sempre diz, o maior investimento que você tem é no relacionamento e o esporte traz isso de uma forma muito abrangente, isso é muito legal

\section{Seleção Brasileira}

Seleção eu joguei a seleção Sub-22, uma seleção que foi campeã SulAmericana. E disputei. Fui campeão SulAmericano com o Adulto, PanAmericano com o Adulto e disputei dois mundiais, um ficamos em décimo e um em oitavo. Foi o da Grécia e de Indianapolis, e assim foram experiências incríveis, ao mesmo tempo que é muito prazeroso você estar com os melhores ali, é extremamente difícil porque a cobrança é enorme, a visibilidade é enorme e exige um foco, força de vontade, um discernimento e até uma resiliência em todos os momentos em que a gente está nesse campeonato.

\section{Visão da Defesa, ouve uma evolução?}

Eu acho que ouve uma evolução sim, porém alguns conceitos se mantêm, eles ainda são modernos. A evolução que eu acho que teve foi muito em função de duas coisas, o atleticísmo, os jogadores estão cada vez mais atléticos, na verdade três coisas, as três já eram importantes, mas hoje são ainda mais. O atleticísmo, os 
jogadores são mais atléticos, correndo muito mais, saltando muito mais, fisicamente estão muito mais fortes. A outra evolução que teve foi por causa do repertório, os jogadores estão cada vez melhores, estão driblando mais, seja ele baixo ou alto, saltando mais para pegar rebote, arremessando mais, na saída de bloqueio com um drible enfim e o terceiro fator que eu acho fundamental, que ouve essa mudança também graças também ao reconhecimento maior nesse fator, é o mental. Os jogadores sabem que se ele não sair colado no bloqueio, o jogador vai meter a bola, porque ele está mais treinado, está com o repertório aumentado, ele está mais atlético.

Então por causa desses três fatores ouve uma mudança, só que as defesas ainda continuam, existe a defesa combinada que eu uso hoje, existe a defesa por zona. A única coisa que eu acho, é que antes era assim vamos marcar dois três com menos regras, hoje já tem algumas regras. Hoje já tem uma defesa 2:3 que eu faço, dando sempre o meio e o meio passa a ser do pivô que defende o meio nessa dois três, assim que o homem do meio ataca a cesta, os dois que estão marcando o fundo e os dois de baixo se adequam a essa situação.

\section{Sistemas Defensivos}

E por causa do atleticísmo e do repertório a gente tem que ter as saídas. Por exemplo, eu estou marcando um bloqueio sem pivô, mas se o jogador me deu um empurrão e saiu do bloqueio, saiu livre. O Pivô sai nele e eu saio no pivô. É uma combinação que você tem que ter, porque se você não tiver esse jogo de cintura, o cara vai acabar arremessando livre. Então a grande briga é para o cara estar o tempo todo focado e cumprir as regras claras que você tem. Mas você tem que ter o discernimento a leitura e até a discussão entre os jogadores e a comissão técnica, do que estar fazendo em situações que são adequadas a isso.

\section{Influência das Regras}

Eu acho que sim, eu acho que sim. Eu não saberia te dizer agora quais regras agora, não conseguiria te dizer. Mas acho que a forma como o contato vem sendo usado, sobre a leitura da arbitragem vem tendo. Eu acho que também foram coisas que foram alterando a forma como defender durante os anos. 


\section{Atleticísmo}

Eu acho que sim, eu acho que sim. Antes, porque eu te falo isso. Antigamente era assim 'eu vou marcar o jogador que não tem muito arremesso', 'ah eu vou marcar o jogador que não dribla muito, então posso dar um pouco mais de ajuda', ainda existe isso, mas hoje a maioria arremessa bem, a maioria dribla bem, a maioria sabe passar. Porque cada vez mais o número de fundamentos dominado pelo atleta são maiores, então esse atleticísmo é fundamental para que você defenda qualquer jogador em qualquer ocasião porque todos os jogadores estão com fundamentos melhores.

Hoje pela intensidade em que o jogo é jogado é impossível que o jogador consiga jogar mais que 8 minutos seguidos, por mais que o jogador esteja bem fisicamente, você precisa trocar para que ele pelo menos descansar 1 minuto e meio e voltar, esse é o mínimo para que ele possa executar as funções dele da melhor maneira possível.

\section{Fundamento Defensivo}

Eu acho que é importante ele ter o conhecimento de conceitos que são importantes, então quando eu falo vamos fazer uma defesa na linha de passe, onde é a linha de passe? É grudado no atacante, é com espaço? Quando eu falo defesa do lado contrário da bola? Onde que é isso, são três passos para dentro, é embaixo da cesta? Quando eu falo em uma defesa primária ajudando um cara que tem muito drible. Aonde é uma defesa primaria, porque a gente não pode esquecer que ele tem que defender ajudando e o próprio homem, então esse é o grande desafio eu tenho que defender o meu homem, mas é um jogo coletivo então tenho que defender coletivamente.

\section{Leitura de Jogo}

Sim, leitura de jogo, e eu acho que é uma das coisas mais difícil de você conseguir passar, você passa muito na conversa, muito com terminologia que eu acho muito importante. Com o meu atleticísmo que não é dos melhores, pelo meu repertório 
que tinha determinadas características que eram muito boas, mas não era um repertório enorme.

Eu consegui jogar Basquetebol em nível internacional, muito por causa da leitura de jogo. Eu, o que eu estava fazendo, em qual momento eu estava fazendo, qual defesa eu estava fazendo, a minha função. E é muito em função ao que os meus técnicos estavam me passando, um pouco na base e muito dessa relação nas equipes adultas. Porque essas conversas, esse discernimento, essa leitura eu acho que faz muita diferença. E entra muita terminologia, a gente discute muito termos e terminologia, um cara fala poste baixo, outro cara fala pivô de baixo, outra coisa.

Então no Brasil precisamos ter uma convergência de linguagem para que as pessoas falem realmente a mesma coisa. Eu acho que faz muita diferença isso.

\section{Classificação clássica}

Eu acho que podemos manter a terminologia, é nós vamos marcar uma 2:3, mas eu tenho uma defesa 2:3 que é básica, mas que na básica damos o fundo e tem uma outra 2:3 que dá o meio, uma 2:3 que dá o meio e não o fundo então são outras regras. Mas são duas defesas 2:3, com dois jogadores em cima e três jogadores em baixo. Só que isso tem que ser uma coisa, hoje eu acho que a coisa é entregue de muito mais mão beijada para os jogadores do que antigamente. Hoje eu falo "olha, aqui vamos dar o meio, esse cara do meio vem na ajuda e esses dois vão flutuar". Antigamente era muito na percepção, na conversa e na forma de agir, estava muito ligada no conhecimento que você adquiria ao longo dos anos, hoje você dá muito mais regras. 


\section{ANEXO I - ENTREVISTA 09}

\section{Visão Geral do Basquetebol Atual}

Bom, nós sabemos que o Basquetebol hoje a grande diferença do Basquetebol hoje é o que eu vejo, existe um quesito físico muito evoluídos dos atletas. A gente tem no Basquetebol eu vejo assim um aspecto básico de domínio de espaço e o espaço é muito pequeno eu acho que nós teremos que ampliar esses espaços que os jogadores têm aqui, porque com o crescimento físico deles né?! $A$ envergadura, o tamanho a impulsão e essas coisas todas, esse espaço acabou ficando cada vez menor.

A uma evolução no Basquete nesses últimos 20 anos para cá, para poder ter um tempo ofensivo para poder dominar e ganhar espaço o tanto quanto for possível para criar espaço para a finalização é o seguinte eu não via a uns 10, 15, 20 anos atrás muito corta-luz longe da Bola, longe da Bola, entendeu?! Bola aqui, corta a luz aqui para livrar. Hoje que a gente tá fazendo a gente tá vendo mesmo é que tem muito pick, pick-and-roll que é o corta luz na bola, então aqui eu acredito que a habilidade do jogador vai prevalecer do que tinha aqui nesse aspecto ofensivamente, por outro lado vai exigir no por parte da defesa, uma reação para evitar o Miss Match, para evitar espaço muito pequeno para o arremesso, hoje os arremessos, os arremessadores estão com inteligência com algo muito forte em relação a eficiência deles, a porcentagem de aproveitamento, então qualquer espaço mínimo que o jogador defesa da isso aí acaba prevalecendo, isso ai acaba favorecendo o ataque eu vejo que o problema de defesa é realmente diminuir ao máximo espaço para o atacante dentro dessa desse, então ou você usa qualquer tipo de defesa que já não se surpreende mais, com tanto recurso Tecnológico de filmagem e tal todo mundo sabe que como se marca, como se marca, quais são os pontos fortes e pontos fracos de quem está marcando, agora eu vejo assim a diminuição de espaço tanto quanto possível do lado da defesa, ai você vai falar 'pô para chegar nesse ponto' o ataque procura ganhar espaço para poder finalizar, ou entrar ou finalizar de fora e a defesa?! O que que faz a defesa? A defesa tem que minimizar ao máximo, eliminar se possível qualquer tempo, espaço que possa sobrar para fazer a finalização, isso é um ponto crucial 
Sistemas de defesa, claro que o individual é aquele que se sobressai, porque você procura realmente forçar o adversário ao erro, né?! Mas ai tem todas as variações do sistema, porque você faz um problema por marcar pura e simplesmente ou então você faz um instante de pressão e sempre podendo carregar 2 em 1 de uma forma possível, ele não mudou muito não, como o problema é de espaço, eu vejo, o tanto quanto possível você tem que, eliminar o máximo na defesa a possibilidade de times infiltrarem no meio do garrafão, né?!

Impedir que se vá ao meio da quadra, ao meio do garrafão, aqui no espaço maior é o fundamental em defesa, tanto numa defesa por zona, quanto em uma defesa individual ou na defesa combinada, eu vejo isso aqui. Então é uma questão de espaço mesmo, espaço mesmo. A defesa tem que diminuir, eliminar a chance de finalização em qualquer espaço mínimo que o ataque, que o ataque pode ter, independente de que sistema de defesa, sistema de defesa vai muito da, do que o técnico gosta, do que o técnico domina, do tempo que ele tem para treinamento, se os jogadores que ele tem em mãos, se eles tem capacidades ofensiva maior ou melhor, pode-se dizer então que defesa por zona então é recurso que os técnicos usam então para diminuir, ou para que possa aproveitar ao máximo da eficiência que o jogador tem, não. Não é esse o caso, não se usa defesa por zona, visando também tentando diminuir o poder ofensivo do adversário, evitando arremessos de meia distância. Então eu vejo isso aqui, se fosse para definir bem seria ganhar ou perder espaço, nesse ponto aqui depois da meia quadra.

\section{Evolução do Aspectos Defensivos}

Talvez em função do crescimento físico dos Atletas, os atletas hoje eles estão com uma vantagem física muito maior, aí você fala 'é o Wlamir por exemplo' o tempo que o Wlamir jogava Basquete era o tempo que se amarrava jogador com linguiça, o Amaury chegou a ser armador, pivô e lateral. Hoje ele para ser lateral, para ser armador eu acho que ele teria dificuldade de jogar, com esse aspecto e também tem o lado, que é outro aspecto que se deve levar em conta é o do contato pessoal, hoje é muito mais liberdade de contato, há muito mais permissão de regras, antes era tocou falta, relou falta, agora não, agora você vê é guerra de corpo embaixo da tabela por 
exemplo, pivô empurrando o outro com o antebraço, isso normalmente é considerado e liberado, então essa evolução ela veio também.

Então eu falo de duas coisas o espaço, ganhar ou perder, na defesa e o predomínio da parte física, hoje você acha um absurdo um jogador como o Stephen Curry jogar basquete, eu estava lendo um negócio sobre ele ontem e ele desafia tudo, o jogador ' $x$ ' vai jogar na NBA?! Não sei, ele não é um Stephen Curry, mas ele vai ter dificuldade para jogar eu vejo, ele vai ter muita dificuldade, agora essa parte, a defesa se adapta a isso, eu vejo que se o time adversário é mais forte fisicamente e tecnicamente e tal, o time eu sendo técnico vou procurar ajustar o sistema, ou individual ou zona ou combinado qualquer que seja para poder eliminar ou diminuir ao máximo essa vantagem teórica que o time adversário possa ter, né?! Eu vejo assim espaço e vamos chamar assim predominância física dos atuais jogadores.

Não existe é claro sistema milagroso, eu vou colocar esse sistema aqui e vou ganhar jogo e os caras vão fazer 50 pontos o jogo todo, isso vai depender muito da condição que você tem para tentar deixar no mesmo nível e tirar, levar vantagem quanto a isso, ai tem os outros aspectos psicológico e todas essas coisas, mas de um ponto de vista técnico-tático mesmo, esses dois, essas duas situações do espaço que eu vejo e o lado de predominância física muito avantajado dos jogadores.

\section{Fundamentos técnicos defensivos.}

É claro, que com essa, digamos assim com esse aspecto físico, técnico, atlético mais evoluído os jogadores acabam tendo, realmente mais condição de defender melhor, trabalho de perda, posicionamento de corpo, tempo de reação saber girar, uma possível, eu me lembro de uma situação, que vem ao caso aqui, o Maury marcando o Michael Jordan, nosso time jogou, nós jogamos contra eles, nós marcando em zona e uma hora o Maury resolveu enfrentar o Michael Jordan, ai o Maury falou assim 'puta, ele ameaçou entrar na esquerda, ai eu falei, ele vai fazer o giro e eu vou pega-lo desse lado, a hora que eu fiz a reação de parar ele já tinha passado, foi tão rápido que eu fiquei sem reação. Eu tinha certeza de que ele iria fazer esse giro e ia passar pelo lado direito meu, eu me antecipei, mas ele se antecipou ainda', quer dizer o lado atlético dele prevaleceu né?! 
Então né, na defesa é claro tem esse aspecto atlético e ele é fundamento e ninguém pode dispensar de uma preparação física dos atletas, você não pode mais encontrar atletas que trabalhem em pé ou que não tenham tempo de reação, quando não há um trabalho de pés principalmente

\section{Conhecimento do jogo}

Eu acho que sim, eu percebo. Veja faz uns 10 anos que eu não tenho militado, que eu não frequento vestiário, mas eu percebo que , o que eu percebo é que os times tem hoje, essas grandes equipes tem muito recurso, essa questão tecnológica, tem uma equipe de São Paulo que faz muito isso, são aplicativos que já existem filmagem dos jogos, não sei se você conhece meu outro filho, ele foi manager da BYU, ele cuidada da parte de vídeos, ai ele ficava, eles tinham um equipamento que as vezes ele ia para a cabina ai o assistente dizia 'Esse ataque' ai ele pegava o ataque, ele editava ali no momento, minuto tal, ele fazia isso durante o jogo, ai o assistente chegava e falava "esse Contra-ataque" ai ele fazia a mesma coisa e tal, ai ele já editava aquilo e na hora do intervalo do jogo eles já passavam aquele vídeo no vestiário, chegava o intervalo o técnico já tinha e falava com os atletas 'veja esse vídeo, isso é um puta recurso, né!? Não dá para você, é.

Eu tenho um ditado chinês que eu uso muito no Basquete, tem muita gente que critica técnico de prancheta eu acho o contrário, e é assim. "Quem ouve esquece, quem vê lembra, quem faz aprende", então ele se aplica muito ao Basquete, não adianta você falar para ele 'faz isso, faz aquilo porque ele esquece', se você mostrar para ele, por exemplo em prancheta que vai lembrar o que ele treinou, e se ele realmente treinou ele vai aprender a fazer, isso aqui no Basquete é fundamental. Então o técnico as vezes fala 'vamos fazer contra-ataque, vamos fazer contra-ataque. Mas ele nunca treinou contra-ataque. 'Vamos fazer dobra na defesa', mas ele nunca treinou dobra. 'Pega agora dois em um na defesa' mas não treinou, então como é que é. Então respondendo mais diretamente à sua pergunta é uma visão mais direta ao Basquetebol. 


\section{Interação Ataque-Defesa}

Não, sem dúvida que mudou, mudou muito a velocidade, com que você sai da defesa para o ataque, sem dúvida que ela mudou. Você hoje usa qualquer situação de posse de bola na defesa dá uma chance de um contra-ataque imediato, para pegar a defesa e um contra pé desprevenida e tal, na NBA você vê muito disso, tomou a bola aqui, pegou a bola aqui, primeiro passe sai aqui, não out range pass, vamos chamar assim middle half court pass, o cara daqui já solta o passe aqui, eles são muito atléticos né?! Antes você fazia assim, rebote, aí passe na lateral, o cara saia aqui e vinha um homem para o meio, agora a bola já sai direto aqui, se possível o pivô já sai aqui para fazer o arremesso de três pontos, essa rapidez, essa velocidade, ela é muito característica.

Uma coisa que eu gostaria de ver, que eu sempre gosto de falar é que aquela seleção de 87 já jogava diante do seu tempo e a gente era muito criticado por isso, se você falar 'isso foi previsto?' não, as coisas iam simplesmente acontecendo naturalmente, a gente dava os exercícios que iam levando o jogador e a gente tendo excelentes arremessadores que nós tínhamos todos eram excelentes arremessadores, não só o Oscar e o Marcel, mas o Paulinho Villas Bolas, o próprio Cadum, o próprio Guerrinha, nós tínhamos jogadores assim que arremessavam muito bem, agora a gente jogava diante do tempo porque os nossos ataques a gente cronometrava e nós tínhamos esses dados, nós atacávamos em nédia 70 a 80 vezes em um jogo e os times europeus de 30/40.

Ataque assim quantas vezes você pegou a bola e foi para o ataque, era quase que o dobro, eu não tenho essa precisão, o que representava o seguinte, o tempo de posse de bola nosso era muito menor, nós tínhamos assim 24 segundos de posse de bola, mas não finalizávamos em 7, 8 segundos essa era a nossa média de finalização do time, mas como você fazia, isso muitas vezes acontecia assim, o adversário muitas vezes tentar fazer a mesma coisa foi a grande chave da nossa vitória, porque os times adversários queriam fazer a mesma coisa, eles queriam atacar rápido e eles não estavam preparados para isso, ai acontecia uma sucessão de erros e o que acontecia era o ataque pumba fazia, nós tínhamos sempre um dos pivôs muito rápidos ou era o Gerson ou era o Pipoca, ai esse pivô a gente não fazia o Trailer, não, pelo contrário trailer nosso era diferente porque o pivô chegava primeiro não por último, ele tinha que chegar antes dos arremessadores, várias vezes o Gerson chegava antes que 
todo mundo aqui, ai pegava o rebote e se dava para finalizar tudo bem, mas muitas vezes você pode ver nos filmes, ele via que não dava para finalizar ai ele devolvia a bola, hoje é o que se faz muito na NBA o cara tenta penetrar, ai não consegue e devolve para o arremesso de fora, porque a grande arma hoje não é jogar aqui dentro é jogar de fora. Talvez pelo ajuste do jogo que a gente tinha, porque nossos pivôs não eram tão eficientes.

\section{Essencial}

Eu acho que uma excelente condição física é fundamental, porque a um esforço muito maior de todas as qualidades físicas, não só velocidade, como força, como tempo de reação e isso exige claro, uma condição física superior, isso ai vai dar com a orientação técnica devida, vai dar a melhor capacidade técnica de sobrepujar o adversário.

\section{Classificação clássicas}

Acho que ela é válida de um ponto de vista acadêmico de literatura é válido, mas sabemos que os demais sistemas além do individual eles dependem muito da condição individual, existem teorias que em categorias menores não se devem marcar zona porque tem que aprender realmente toda a preparação de uma marcação individual e eu também acho isso. Nas categorias menores você tem que realmente dominar os fundamentos defensivos Básicos, mas acho que esses fundamentos técnicos defensivos individuais prevalecem e depois vocês ajustam eles ai em mistos e combinados e pressão.

\section{Sugestão}

É você pode, por exemplo existem os mistos e combinados, depende de quem está classificando isso até o chamado Box one, Match up zona, eu vejo que essa classificação é o que te dá uma ideia principalmente para quem recebe a informação. Já foi o tempo de que alguém fazia uma Match up Zona e surpreendia o adversário, para os caras ficaram batendo cabeça isso naqueles times montados taticamente, mas acho que essa classificação pode surgir, pode liberar algo diferente. 


\section{ANEXO J - ENTREVISTA 10}

\section{Basquetebol Atual}

Eu trabalho da seguinte maneira, eu gosto do começo da temporada, eu coloco muito para eles que a gente começa a temporada com uma mochila vazia então a gente tem que durante a temporada que usar vários instrumentos que estão nessa mochila, se a gente fica com a mochila vazia e ai você vai precisar de algum instrumento que você não vai ter e vai ficar difícil, então no começo da temporada a gente tem que correr atrás desses instrumentos que você pode estar precisando.

Então no começo o que que eu faço?! Eu passo para eles, eu coloco para eles o máximo possível de conteúdo, tanto defensivos, quanto ofensivos, várias estratégias, é claro que eu coloco a característica da equipe. Mas é mesmo, independente da característica, eu coloco para ele várias situações ofensivas e defensivas, porque?! Porque pode ser que lá na frente você precise de alguns instrumentos que estejam na sua mochila é você procurar, resgatar e usar.

Então para mim a pré-temporada é muito importante por causa disso ai, agora também não adianta nada você estar com a mochila cheia, carregar e não usar, então o que a gente faz. A gente coloca esses instrumentos, então coloca uma cara, coloca uma ênfase no time. Nossa equipe, a característica da nossa equipe é defender muito bem o individual, com defesa de pick-and-roll com troca, fazendo uma rotação e sempre quem ajuda é o lado que tá com dois e com isso a gente vai colocando situações que a gente coloca muito de acordo com a característica da equipe, então a gente coloca todos os sistemas, a maioria né?! Todos é ousado falar, porque cada vez aparecem sistemas novos, né?! Mas a gente coloca muitos sistemas então a gente vai usando a medida do possível.

Eu gosto muito dos sistemas de defesa individual, agora o sistema de defesa individual te permite defender de diversas maneiras, né?! Dependendo também da situação do adversário e outra coisa que eu também gosto de usar muito, que me ajudou de mais nos sistemas defensivos é saber a característica do adversário, 'então você vai jogar de acordo com cada equipe?' Não, eu vou jogar de acordo com as características do adversário. Só que essas características elas podem ser do ABC 
ou do $C D E$, não necessariamente de uma única equipe e a cada partida eu tenha que me remodelar, entendeu?!

O adversário pode ter uma característica de não ter um arremesso bom de média e longa distância, eles tem uns laterais que tem uma característica maior de penetração do que de arremesso, então dependendo da característica do adversário a gente tem uma maneira de defender já pré-estabelecida, então eu uso como um alicerce, uma base o sistema defensivo individual, os scouts e também muito do que as características do adversário me dá e o scout tem me ajudado muito nisso, no nosso trabalho, no nosso trabalho o scout é uma coisa que ajuda demais a gente a defender, inclusive ajuda a induzir o adversário a atacar também de uma forma com que minha defesa esteja mais adaptada, então eu trabalho como base o sistema de defesa individual, o Macth-Up, Zona, Combinada e também uso muito as defesas combinadas começando com uma zona e terminando em uma individual ou em individual e terminando em zona, mas então eu gosto de colocar nessa mochila ai vários sistemas defensivos e depois ir usando conforme a necessidade.

\section{Evolução do Basquetebol}

A evolução é muito grande, a cada dia o Basquetebol tá evoluindo, se você ficar um período achando que o que você tem de conhecimento é o suficiente para uma temporada você está ficando para trás, até o acesso a esses conteúdos a novas tecnologias de trabalho é muito fácil atualmente, então a evolução acontece muito rápido e praticamente dia-a-dia, então a gente tem que estar sempre estudando observando as situações, adquirindo os conteúdos, mas acho que mais do que isso é saber lidar com esses conteúdos, mas acho que isso é uma coisa que é fundamento, as vezes a gente está cheio de conteúdos sabe de todas as coisas, mas não coloca em prática e as coisas acabam não dando muito certo. Então eu vejo a evolução muito grande tanto, dentro de quadra dos conteúdos propriamente ditos e como utilizar esses conteúdos, a forma de aplicar esses conteúdos que para mim tem evoluído muito rápido e de uma forma surpreendente.

\section{Evolução defensiva}


Acho que muito, como evoluem os sistemas ofensivos. Porque eu acho que evoluem. Porque o jogar está ficando cada vez mais versátil, então nós estamos vendendo o Basquetebol moderno com jogadores que não tem somente um posição, então para o jogador para que ele tenha espaço, condições de jogar, mais tempo ele tem que ser versátil. Então até aquele jogador grande com características de jogo interior ele já tem que começar a ter que ter uma variação de jogo, de sua maneira de jogar e isso faz também que a defesa tenha que mudar sua maneira de jogar, ela evolui. Então os sistemas ofensivos eles estão se modernizando, eles estão sendo bastante variados e os sistemas defensivos acabam evoluindo e buscando uma maneira de parar $o$ ataque.

\section{Fundamentos Defensivos.}

É uma coisa que eu falo muito para os meus jogadores, existem duas partes na maneira de jogar, na maneira não, no jogo propriamente dito, é a parte de estratégia, a parte estratégica e a parte de execução, eu posso ser o melhor técnico do mundo, eu posso ter todas as soluções de uma maneira teórica estratégica, tática, mas eu dependo da execução, eu dependo que essa estratégia, que essa tática tenha sucesso, se a execução ela for boa e a execução ela depende do jogador, para que eu tenha sucesso nisso sem dúvida nenhuma, para que essa execução tenha qualidade é fundamental que o jogador tenha essa, capacidade e essa habilidade de poder executar as ações que a tática exige. Então, eu acho que é fundamental, a gente não pode nem dar o passo dois se a gente não falar da primeira parte que é a parte técnica que é a parte da execução então eu falo para eles, se vocês querem errar, que errem na parte tática, na parte estratégica, porque isso é culpa minha e não de vocês, então não errem na parte de execução porque aquilo que for determinado tentem executar da melhor forma possível, porque se tiver algum erro, algum insucesso nisso que seja culpa minha e não culpa sua.

O que eu vejo muito hoje é uma preocupação de estar evoluindo taticamente de encher aquela mochila que eu falei de elementos, mas na hora que você tem que usar tem que saber usar esse elemento, se você não tiver habilidade para manusear essa ferramenta, entendeu?! Então a gente coloca esses elementos nessa mochila, como eu vejo os aspectos táticos, mas a gente ensina a manusear então da mesma 
maneira que a gente enche de técnica, tática e estratégia e de fundamentos a parte individual.

Eu acho que isso ai é o ponto chave, muito vem e isso facilita de mais, quando a gente começa a trabalhar com isso nas categorias de base, que eu acho que a gente muito a melhorar, a gente não tem uma metodologia, a gente não tem uma didática, a gente não tem um conceito de jogo bem definido, então eu acho que tudo isso ai.

Dificulta um pouco ai a gente tem que resolver taticamente, ai chega em um momento do jogo que a gente vai ter que tentar usar uma outra estratégia porque a gente não está conseguindo executar, porque a gente não está conseguindo ter a habilidade para defender, então a gente vai ter que fazer um outro tipo de defesa porque eu não consigo defender em situação de 1 contra 1 , então acho que são coisas que a gente não pode deixar para trás acho que a parte de fundamentos, a parte técnica, assim como a parte tática tem uma evolução a parte técnica também tem que ter uma evolução, vamos pensar na formação que é onde a gente ensina o B a BA e depois esse manuseio das estratégias que a gente tem pela frente.

\section{Conhecimento do Jogo.}

Uma coisa que eu costumo falar, principalmente nas palestras que eu dou, principalmente Sub-15 para cima, a gente não tem uma leitura de jogo, as vezes a gente terceiriza isso, a gente fala que o Jogador não tem a leitura do Jogo, mas é a mesma coisa que você pegar um aluno que está aprendendo a ler e dizer, 'meu você não sabe ler', 'é claro que eu não sei, você não me ensina', então ninguém ensinou, eu acho que é muito da gente de nós técnicos fazermos essa mea-culpa e ver o quando que a gente contribuiu para que o jogador tenha uma leitura de jogo e o que eu volto a falar lá das categorias formativas, se você não tem uma metodologia, se você não ensina o atleta a ler o jogo, como é que você quer que ele tenha essa leitura, ele não tem como.

Ele vai, alguns pelo talento claro, mas mais pela inteligência individual que ele tem, ele vai conseguir pegar as coisas individual e entender o jogo, mas eu acho que isso não é, a gente não pode depender só do talento, a mesma coisa em situações técnicas, né?! A gente fala assim, jogador é talento e a gente falava muito isso quando eu estava na confederação, quando a gente assumiu um período, mais uma 
coordenação das categorias de base é que a gente não pode depender do talento, porque se a gente depender do talento, no dia que tiver talento a gente ganha, mas quando não tiver a gente perde e a gente não pode ser assim, a gente tem que depender do trabalho.

Esses talentos são importantes? Lógico que são, mas a gente tem que fazer que esses talentos se potencializem com o trabalho e que a gente não dependa só do talento para ganhar o não. Porque a gente tem um trabalho muito forte, é o que eu acredito.

A gente tem que usar alguns jogadores que tem essa inteligência de poder entender, que tem uma leitura melhor para que eles potencializem esse trabalho de leitura coletiva, eu acho que isso vem muito da formação, então você ensinar a ler, acho que os técnicos das categorias de base, acho que a gente precisa valorizar um pouco mais esse trabalho, porque se a gente que ter um trabalho depois lá nas categorias adultas, de qualidade, a gente depende desse trabalho de formação, então esse trabalho de formação, esse trabalho de base ele precisa ser mais valorizado.

Eles precisam ter mais elementos para passar para os jogadores, eu acho que o trabalho principal, eu acho que tem que ser a partir dessa formação, porque depois na categoria adulta, você consegue mais coisas, você consegue ter mais acesso, você consegue ter mais conhecimento, consegue ter mais troca de informação, mas eu acho que na categoria de base é muito carentes disso, precisamos fomentar esse trabalho e eu acho que essa leitura de jogo depende muito desse trabalho de formação, para que depois é claro você vá usando esse tipo de leitura e um jogo de xadrez que existe no Basquete adulto.

\section{Essencial}

Tem alguns aspectos que são fundamentais, que eu acredito, é a parte de fundamentos, são os fundamentos individuais de defesa, deslocamento, posicionamento de defesa, que o Dante ensina lá, posição básica de defesa e deslocamento e é isso que é o fundamento que é o conceito. Estou falando de fundamentos individuais de defesa, que difere de sistemas individuais de defesa, para que você tenha uma qualidade de você conseguir ter uma boa postura para que você tenha um bom deslocamento nessa postura, para que você tenha isso de qualidade, 
eu acredito muito que não pode desvincular da parte física, eu acho que o sistema de defesa qualquer que seja ela é não pode ser desvinculado da preparação física.

É uma coisa que eu não consigo desvincular, dessa parte física, porque a maneira que eu acredito que tenham que jogar o Basquetebol depende de mais da parte física. Você pode saber o que tem que fazer, você pode saber o fundamento, sabendo como tem que ser executado e com uma qualidade do fundamento, mas para você executar ele durante a maior parte do tempo você precisa ter uma preparação física adequada para isso.

Então eu não consigo desvincular os fundamentos principalmente os defensivos no Basquete da parte física eu acho que é o fundamental isso e isso eu acho que vem da base, você precisa ter uma base, uma estrutura motora para executar esses fundamentos de uma maneira adequada, não só do fundamento, estou me referindo a habilidade, mas também da capacidade física, então as capacidades físicas são específicas do Basquete, para executar aquilo, então eu falando de uma maneira geral estamos falando de velocidade, força, equilíbrio mas que tudo isso seja especifico para o Basquete, eu acho que isso são coisas que a gente não consegue desvincular para uma qualidade na execução

\section{Classificação dos Sistemas defensivos}

Acho que é como você falou é uma coisa clássica, porque esses conceitos desses sistemas, vamos dizer que eles são o alicerce dos sistemas defensivos, eu uso muito isso sistemas defensivos pressão, individual, mistas e combinadas, só que a maneira de executar você tem alguns braços, alguns ramos, então ai por exemplo sistemas defensivos individual, tem diversas maneiras de executar os sistemas defensivos individual, tem diversas maneiras de você executar a defesa individual, qual a característica é situação de um contra um, mas um contra um como isso, você vai fazer um sistema de contenção, de pressão na bola, direcionando o jogador para situação, então eu acho que a maneira de executar esses sistemas varia bastante. Eu acho que é também a maneira como você se adapta a característica da sua equipe e a característica do adversário. 
Hoje no Basquetebol de alto nível, é impossível você desprezar a característica do adversário, ou você usa o scout porque ele te diz muita coisa, porque ele te direciona, a gente já ganhou títulos por conta do Scouting, talvez um título que tenha sido o mais expressivo foi a copa intercontinental, contra o Maccabi Tel-Aviv, a gente tinha muita informação do Maccabi, a gente tinha muita e eu acho que isso surpreendeu, porque eu acho que eles viram a gente e pensaram eles sabem como a gente joga e como a gente tinha que ganhar, duas partidas ou ter um saldo melhor nessas duas partidas, então jogamos com isso.

Fomos ver o que é o ponto fraco deles, para jogar em cima disso e o que que é o ponto forte deles, para neutralizar isso a gente direcionou a nossa maneira de defender a nossa característica de jogar muito com o que eles iam fazer, só que era só um adversário, só que acontece às vezes, pode acontecer nos playoffs 'o time encaixou'.

Eu acredito que esses sistemas não mudam, você tem lá a maneira de defender no sistema defensivo individual e você vai olhar e falar ele está marcando individual, está defendendo zona, está defendendo uma defesa mista, uma defesa combinada, a partir de uma situação eles estão trocando o sistema, a pressão, muita característica de como estão marcando a pressão, é quadra toda, meia quadra. Então eu acho que a característica das nomenclaturas elas não vão mudar, mas a maneira como vai se aplicar, ela vai mudando com a evolução do Basquete.

\section{Sugestão}

Conforme a evolução do Basquete você vai criando uma maneira de defender, por exemplo a gente teve um tempo, um período, eu acho que nós fomos uma das primeiras equipes que a gente sempre trabalhou com defesa individual e de acordo com ataque, como por exemplo quando tem um movimento de bloqueio direto né?! Do pick-and-roll, a gente faz troca, nós fomos uma das primeiras equipes, quando a gente ganhou lá em 2014 acho, que isso foi surpreendente, jogamos contra um adversário que tinha um time muito forte e estava super bem no campeonato e se classificou em segundo eu acho e a gente ficou em terceiro, então a gente jogou um playoff semifinal contra eles e eles jogavam muito bem nos conceitos a partir do pickand-roll e tinham jogadores que jogavam muito bem saindo do pick-and-roll com 
características de 1 contra 1 do Basquetebol Internacional, com jogadores que tinham uma habilidade muito boa de jogar no período e utilizamos uma defesa que tinha troca.

Quando eu treinei até minha equipe ficou surpresa, caramba você tá louco você vai colocar o pivô defendendo o armador deles, só que nós vamos fazer isso, nós vamos induzir eles a jogarem dessa forma e na troca nós vamos dar esse caminho para ele, queremos que eles joguem dessa forma.

Então fizemos eles jogarem uma defesa individual de forma coletiva. Mas o que eu estava fazendo era tirando a característica de um contra um dele, induzindo eles jogarem um contra cinco e a característica de um contra um da defesa individual não estava acontecendo mais e eu estava induzindo eles a jogarem um contra cinco, com um defensor e mais quatro jogadores ajudando e com isso a gente estava controlando o ataque do adversário e isso deu muito certo, a gente ganhou de 3 à 0 a série, de uma maneira que o primeiro jogo acabou por 30 pontos, o segundo acho que 20 pontos, foi um negócio que não deu adaptação para eles, porque estávamos usando um negócio diferente.

Então estávamos usando uma defesa individual, só que a partir de uma situação do adversário, que ele faz uso de um bloqueio direto a gente faz uma maneira diferente de defender a gente trocava e eu acho que são várias situações que vão acontecendo e que vão mexendo na situação de jogo com o adversário.

Eu acho que todas as situações de jogo, tem que serem levadas em consideração e o técnico tem que pensar em uma estratégia e tudo vai evoluindo com a evolução do jogo, todas as estratégias, é um esporte coletivo então você tem que pensar no todo, não adianta você pensar só na execução de um jogador, você tem que pensar numa estratégia de uma maneira coletiva, o Basquete é uma modalidade coletiva, defensiva e ofensivamente, mesmo em uma situação de um contra um você tem que posicionar seus jogadores de uma forma que 'a o jogador está criando uma vantagem no um contra um ofensivamente' se vem uma ajuda o que você faz, joga a bola para cima e sai correndo?!

Não você se posiciona de uma maneira que se vier uma ajuda você consegue passar e receber em uma posição de arremesso, na defesa é a mesma coisa, se você está em uma posição que vê que o adversário vai levar vantagem nesse um contra um, você se posiciona, você já procura trabalhar a ajuda e a rotação a partir disso, então eu acho que a maneira de você executar essas subdivisões, é que ai está inserido muito, sistemas de defesa individual, Okay! 
Você usa várias maneiras, ai vem um pick-and-roll, o que você usa? Okay. Defendeu, qual a rotação que você faz, o que vem, o que acontece?! 


\section{ANEXO K - ENTREVISTA 11}

\section{Visão do Basquetebol Atual}

A Defesa sempre foi fundamento em Basquete, sempre teve um valor, mas é assim quando me ensinaram a jogar Basquetebol meu pai veio para mim e disse assim, 'o Basquete se chama Bola ao Cesto, você treina o cesto', ele falou isso de verdade. Bola ao Cesto, bola no cesto, então você vai treinar o cesto e aí nos anos 70 anos 80 , que antes disso eu não sei falar né?! Falar da época que eu jogava, ganhavase o jogo fazendo mais cesta que o adversário tá?! Aí nós temos o máximo, isso foi no Pan-americano que nós ganhamos dos Estados Unidos assim, mandando bola de três, a partir dos anos 90 isso aí começou a se inverter, né?!

E começou-se ganhar jogo fazendo adversário fazer menos pontos que você, ia ser por causa da defesa ou porque você segura a bola, que é o que eles fazer no futebol, que quem tem mais a posse de bola ganha o jogo. Você segura a bola 32 segundos, estou falando assim exagerando, mas por exemplo no College Americano você pode segurar por 35 segundos, né?! E aí você só chuta quando der, na boa mesmo ou então você tem defesa aí começava se aparecer vários tipos de defesa, mas isso já mudou também.

Hoje o que a gente vê, hoje o que a gente vê é que o basquete é o jogo mais individualista do mundo, mais individualista individualizado do mundo. Em todos os esportes não tem um jogo coletivo tão individualizado, como o do Basquete. Isso Começou lá nos Estados Unidos com alguns jogadores e hoje você vê o LeBron James pegar a bola, abrir todo mundo e ele vai jogar todas as bolas, assim, ou ele passa ou ele vai, mas ele individualizou um jogo coletivo.

Na minha opinião o que nada mudou desde a minha época até hoje é que não existe defesa se não tiver pressão na bola, se o cara que tá com a bola não estiver pressionado pela defesa, ainda mais nos dias de hoje, ele vai fazer o que ele quiser $\mathrm{e}$ a minha crítica para defesa no Brasil sempre foi essa, nós não fazemos uma pressão na bola.

Então quando a gente ganhava o jogo fazendo mais cesta que o adversário isso nem aparecia, mas na minha época já tinha Franca que fazia isso briga no jogo do Sírio, nessa época eu joguei no Sírio, que eram os dois times, e ganhava jogo do 
Sírio, tinha a Argentina que já fazia isso e já ganhava jogo do Brasil em SulAmericanos, não ganhava em mundial e olímpiadas na minha época, então a única verdade durou e perdura até hoje para mim na defesa é a lei de pressionar o cara da bola se esse cara não tá pressionado não tem defesa que resista.

E é o que está acontecendo hoje é que o cara muda a defesa, para homem, o pop, 1:3:1, 3:2, mas se ele não botar pressão na bola nenhuma funciona, isso é uma verdade absoluta, o cara hoje com a posse de bola sem levar pressão vai ver o que ele faz, faz isso como LeBron James, faz isso com o Magic Johnson, faz isso com o Michael Jordan, eles já faziam tudo isso com três neles, você imagina se deixar ele lá, ele faz o que ele quiser.

Uma vez teve um jogo que o técnico falou assim "Ah! O jogo é contra o Oscar, ele vai fazer 30 pontos de qualquer jeito né!? Então vamos marcar os outros e deixa - Oscar, o Oscar meteu 59 pontos e o técnico perdeu o emprego. Se marca o Oscar e do jeito que você marca o Oscar ele faz 33 pontos de média ai você fala 'não marca os outros' Porque ele te mete 33, então ele vai e te mete 69. Hoje em dia eu falava isso na época do basquete ganhava com mais, com mais, fazendo mais cestas do que o adversário nego dava um pau, hoje a turma está entendo mais isso porque a defesa conta.

\section{Aspectos Defensivos}

No Brasil nunca teve defesa, não existe, se você for, se você for analisar como se deve uma defesa, no Brasil ela nunca existiu, porque teve é uma pressão muito grande na arbitragem para você defender com a mão, para deixar você segurar, deixar você fazer e segura a bola no ataque, é isso que existiu no Brasil, sempre. Você pode até ter estudado defesa você falar dos caras pô e tal. Mas quando você ver que não tem defesa, não tem pressão no cara da Bola causa da Bola jogar sozinho e faz as coisas.

Hoje em dia gente, hoje em dia?! Sempre foi assim, o cara segura, apita falta, ele reclama uma, reclama duas, reclama três, aí vai na federação o técnico tem poder, o diretor tem poder, tudo isso colabora para pressionar o arbitro para não marcar falta. Nossos árbitros são os melhores do mundo, tanto é que a gente tem um monte de arbitro que já apitou o final Olimpíadas e não erram e não fazem porquê!? Porque fora 
do Brasil existe o jogo, existe a defesa, aí nós vamos discutir. Mas se você discutir no Brasil Defesa, não existe, porque primeiro não existe pressão no homem da bola, segundo você pode defender com a mão, segurar o adversário, empurrar o adversário e tudo né?!

Daí você pressiona quem apita falta, se você tem mais poder pro seu time apitam para caramba e em terceiro você segura a bola e só, isso ai foi levado à exaustão nos Estados Unidos na NCAA, que os jogos começaram voltar a ser 30 à 25 e falaram para com esse troço aí, porque eu fico com a bola e é isso ai.

\section{O Basquete FIBA como um todo (Euroliga)}

O Basquete da Euroliga tem defesa, tem defesa porque o juiz não pode ser pressionado, os jogadores são mais habilidosos no ataque, que os nossos e você tem que botar pressão no cara na bola e fazer a defesa atacar o ataque. Por que a defesa o conceito de defesa para mim, que existe, quando existe defesa é quando a defesa ataca o ataque, o cara está com a bola ele não está reagindo ao ataque do adversário, entendeu?! Nem um pouquinho, ele não está reagindo.

\section{Essencial}

Se você fosse colocar, como você já coloca muito a questão da pressão na bola então para falar de um fator essencial defensivo seria o quanto essa defesa consegue impor de pressão na bola, ou você colocaria mais algum outro ponto.

$\mathrm{O}$ quanto ela consegue atacar o ataque, porque as vezes você fica em uma atitude passiva na frente do cara e acha que está marcando, então você gruda no cara e segura ele com a mão e acha que está atacando, não deixa ele correr para lá, não deixa ele correr para cá, ai você vai jogar um jogo da Euroliga, ou do campeonato mundial e você se ferra.

Nós vimos isso dos anos 90 para frente, nós vimos isso 20 anos, se pregava a defesa aqui no Brasil nós temos que dizer tá vendo como a gente defende e não se quer que o jogo mudou porque não é mais o de ataque, não sou eu que tô falando olha o resultado, cara que jogava aqui no Brasil, não jogava na Seleção Brasileira, porque?! Porque ele não consegue jogar, faz três faltas se quiser defender como 
defende vai para de pressionar a bola e de botar pressão para de atacar o ataque, aí você vai jogar como nós fazemos e aí, como é que faz?! Entendeu?

Aí na NBA mudou tudo, aí nós começamos aprender muito sobre rotação defensiva na NBA, sobre tudo. Mas hoje, filho, hoje é assim abre tudo e joga um contra um, jogo de um contra um como que faz para colocar pressão na bola?! Você tem que fazer sempre a defesa marcar o atacante, porque agora é um só, então agora como vamos defender o LeBron James. Nós vamos defender o LeBron James em dois em três porque você e aquele outro jogador, você vai cobrir assim, quando ele entrar para esquerda não temos que com dois nele.

\section{Classificação}

Se você colocar pressão na bola é válido, se colocar pressão a individual, defesa por zona, defesa combinada, é pressão, sem pressão na bola não existe nenhuma delas. Você vai marcar zona hoje e não vai marcar pressão no homem da bola?! O cara acerta de oito metros o chute e você vai ficar esperando na zona e deixar o cara chegar a 2 metros da linha de 3 pontos mandar bala, vai?!

Então você vai ter que colocar pressão na bola e depois você vai marcar por zona, depois você vai marcar combinado, depois você vai marcar boxe. Lógico que existe tudo isso e você tem que ensinar isso para o cara que tá começando.

\section{Sugestão}

Não, hoje em dia você precisa de tudo isso, mas a realidade do jogo mudou, como você vai marcar por zona, tem que ensinar, o Basquete é um processo, como se deve, como faz a você vai em um treino da Telma é aquele treino que tá treinando fundamento, ué?! Você tem que ensinar para criança isso, você não pode pegar a criança no sub-13 e pegar abre cinco, fica só esse aqui porque é habilidoso e vai jogar, vamos defender esse cara assim, assim, claro que existe tudo. Só que quando você vai jogar nível de NBB para cima, você tem que pensar se o cara que está ali já sabe tudo isso e que dentro disso ele tem que atacar o ataque e botar pressão na bola, principalmente, depois tem as rotações e um monte de coisa, né?! 


\section{ANEXO L - ENTREVISTA 12}

\section{Visão Geral do Basquetebol Atual}

Basquete que tem que ser jogado da mesma maneira dos dois lados da quadra para cada time, isso eu tô nas entrevista com jogadores e técnicos e isso é tecla que todo mundo bate muito e não é só falar na entrevista, não tem muitos times que realmente se organiza a partir da Defesa porque, porquê fazer uma boa defesa pressionando a bola forçando adversário a fazer arremessos que ele não tá, tão acostumado ele não só vai diminuir a porcentagem de acerto do time adversário, como também vai ter a bola para jogar em transição eu vejo isso muito em uma equipe aqui de São Paulo, 'há ela não marca, a ela não, o técnico mudou', não o técnico reestruturou time dele para a partir de uma defesa pressionada faz o adversário as vezes errar ou chutar rápido ele tem a bola obviamente isso é vinculada a você ter um bom trabalho de rebote, mas é isso que vai te levar contratar e o contra-ataque no Basquete talvez seja uma coisas muito mais valiosas.

Porque no jogo de 5 contra 5 tem muito estudo, hoje em dia está muito fácil entre aspas para o treinador estudar último adversário como é aquela jogada, como que aquele jogador pontua no 5 contra 5 de meia quadra, então eu vejo a defesa é primordial para você contratar aqui, eu acho que é MaxFactor no Basquete hoje, quem contrata, quem joga em transição, são os times que tem sucesso, são o Warriors, o Rockets, aqui no Brasil é essa equipe, são times que se propõe a jogar dessa maneira para você jogar no 5 contra 5 , você tem que ter um time muito bom, tipo uma equipe do Rio de Janeiro, ela não precisa defender muito bem, porque no jogo de meia quadra, ele vai ter um ala que é um fator de desequilíbrio, ele tem o pivô que desequilibra qualquer defesa, agora outro pivô, fora os outros caras que estão ali paradinhos para receber uma bola e arremessar.

Agora se você não tem tanto esse desequilíbrio, mas se você não tem tanto esse desequilíbrio se você quer jogar em transição, você tem que defender a defesa vai ser é o papo de entrevista que eu mais ouço, há a agente tomou trinta pontos, mas é o que realmente funciona hoje. Se você não tiver a bola na mão, uma boa defesa você não vai conseguir ter sucesso no basquete moderno. 


\section{Técnicas defensivas}

Eu vejo algumas possibilidades a primeira é que hoje em dia a maioria dos times baseia-se o jogo do pick-and-roll e hoje em dia existem várias maneiras de se defender o pick-and-roll, você pode, se o cara não arremessa tão bem você vai passar por trás, se você tá jogando com um cara que você quer tirar o volume você vai dobrar e fazer ele passar a bola, se você tá jogando com um cara que tem um bom arremesso e vai sair junto e o pivô não vai poder porque o outro pivô vai ter que girar para fora, então eu acho que talvez isso seja coisa mais importante do basquete hoje, uma sincronia de todo mundo para que haja uma rotação para defender o pick-and-roll.

Porque o pick-and-roll hoje em dia é letal, todo mundo joga com o pick-androll tanto o cara da Bola quanto o cara que vai dar o roll ou o pop-out, então eu acho que isso talvez seja mais importante hoje obviamente, que ai a gente vai falar de outras coisas de técnicas de 1x1, de postura, de como eu vou um jogador de e gosta de driblar, eu agora em um jogo no Sul eu vi o ala de uma equipe, que é um menino de vinte poucos anos fez o primeiro tempo absurdo, ele anulou o ala do adversário cara, como você anula o esse ala no um contra um?

Com a mão alta, base, quando ele dar o drible você já encosta nele, porque ele vai querer dar uma volta para arremessar rápido. Então eu acho que essa sincronia, a técnica defensiva e o um contra um na defesa são muito importantes, porque existem jogadores que dependem de um contra um e se você conseguir diminuir um pouquinho volume de você vai ter sucesso no jogo de basquete, mas eu vejo como mais importante talvez hoje é essa sincronia entre os cinco caras na quadra, os cara estarem se falando.

Hoje em dia a gente sabe que tem que técnico que faz troca tripla porque são muitas as possibilidades que o Basquetebol Moderno dá, estão usando muito um pickand-roll que ainda vai um outro cara faz um bloqueio cego no pivô para sair para chutar, então se a defesa não estiver muito atenta, ela vai tomar uma cesta fácil porque o nível warriors, todo mundo hoje em dia se movimenta sem bola, então se você não tiver falando, atenção acho que você não vai ter sucesso defensivo, na minha visão uma boa defesa, passa por uma boa comunicação em primeiro lugar.

\section{Ataque $x$ Defesa}


Eu acho que o ataque de força defesa a mudar o pensamento, o basquete mudou muito, de uns 5 ou 8 anos para cá. Chutar bola de três em excesso era algo sempre visto como algo pejorativo, negativo e que só o Brasil faz e que países não faze, hoje em dia, acho que muito pelo Warriors mesmo, revolucionou um pouco o jogo e o ataque forçou a defesa a tá mais ligada, mais atenta.

Esse lance que eu comentei na resposta anterior de ter uma comunicação boa porque os caras estão se mexendo o tempo todo então vamos trocar tudo, 'com esse cara não dá' então troca e se a defesa não tiver muito ligada ela permitir cestas muito fáceis e vai abrir muito o leque de oportunidades que um ataque tem hoje em um jogo de Basquete, fora o atleticísmo dos jogadores meio Darwin parece, uma evolução natural então hoje em dia os caras conseguem coisas que a 10 anos atrás não conseguiam e talvez daqui a 10 anos a gente veja os caras fazendo coisas mais impressionantes ainda.

Eu acho que tudo isso força a defesa a mudar um pouco, a pensar meu eu penso assim, se eu jogasse na NBA e se eu fosse armador e eu vou jogar contra o Thunder como eu vou marcar o Westbrook, o que que eu vou fazer para parar esse cara, então eu acho que jogadores desse nível desse calibre aqui no Brasil você pode pegar o jogador ' $x$ '. Caramba como é que eu vou. Não vou tomar um crossover dele? Então eu acho que o ataque e evoluiu muito, o basquete mudou muito e isso forçou a defesa a ter um brio diferente um enfoque dentro do jogo.

\section{Classificação Clássica}

Eu acho que esses sistemas são divididos sim, mas eu acho que no basquete profissional de alto nível eu vejo que tá cada vez mais vezes marcar a zona, claro que você vai ver situações em que equipes vão marcar zona e vão ter sucesso porque o adversário não vai ter um bom aproveitamento, mas e se o adversário tivesse um bom aproveitamento?

O técnico ia ter que ter mudado, obviamente deu certo eles meteram 20 pontos no jogo dois e depois do jogo 3 os adversários já estavam um pouco desestabilizados, porque eu acho que essa defesa teve total parcela nessa desestabilização podemos dizer assim porque era um time que não teve um bom aproveitamento das bolas de três na temporada. 
Só que eu acho que o basquete de alto nível e não vejo que defesas combinadas e defesas pressão possam ser 100\% eficientes, eu acho que em uma situação específica talvez você consiga, mas no Basquete profissional de alto nível, eu vejo que é uma defesa individual muito bem sincronizada para ela funcionar.

\section{Sugestão}

Eu acho difícil algo diferente de uma defesa individual que vai ter, que ela vai ser personalizada, vamos dizer assim, cada técnico vai customizar ela de um jeito, 'vamos marcar individual dar o fundo para os caras e o pivô dobra', 'vamos marcar individual com esse cara, todo o pick-and-roll dobra', então eu acho que toda essa personalização e se a gente personificar, tipo se basear no seu adversário para construir essa personalização.

Eu acho que é isso que que faz sentido hoje no basquete moderno, você olhar pera aí, eu jogar contra a equipe ' $x$ ', 'como eu vou marcar o pick-and-roll do dos armadores, será que eu vou marcar do mesmo jeito? Não' então essa personalização que eu acho que é o que dá o diferencial de uma defesa para outra, claro que situações de zona, ou de pressão, ou de uma defesa combinada, que é difícil no Basquete de alto nível profissional.

Você também vai ter que ter esse ajuste, mas eu creio que hoje o basquete passa por uma defesa individual até porque os caras hoje em dia arremessam de três, todos os caras tem aproveitamento, então é muito difícil você achar uma maneira de sair disso e cada um pega o seu e vamos se falar, 'com esse cara é isso', 'com esse cara é aquilo' e 'quando o pivô subir', enfim, hoje em dia os caras sabem todo playbook do adversário, hoje tem o Cinergy e diversas outras mil ferramentas que permitem, aqui no Brasil né?!

Não falando nem da NBA, mas aqui no Brasil os técnicos estudam, muitas vezes eu vejo os caras vem batendo e chama a dois, quando ele chamou a dois, o armador tá marcando já fala, 'o é a dois, vai fazer o pick'. Então os caras já sabem vai ter dupla ali, ou corta-luz fora da Bola. Então essa customização da Defesa que eu acho que é o diferencial hoje em dia você se adaptar o adversário e os a situações que te favoreçam na defesa. 


\section{ANEXO M - ENTREVISTA 13}

\section{Visão Geral}

Hoje no basquetebol nós não temos matéria-prima, matéria-prima são os jogadores para defender internacionalmente o Brasil nas grandes competições, eu vejo um problema muito grande que sempre é falado, mas não é feito é o trabalho de base, principalmente pelos jogadores que são incutidos hoje a pensar numa NBA, não é nem pensar primeiro em uma seleção local, na seleção paulista, carioca e depois em uma seleção brasileira, para depois pensar nas grandes conquistas dos grandes mercados e isso é uma coisa que é muito preocupante e que você vê que tem vários jogadores com um potencial muito grande e que já foram fazer testes na NBA e quando voltaram não conseguiram jogar mais aquele basquetebol que estavam acostumados.

Já ficaram perdidos no meio do caminho tem vários jogadores que aqui para o consumo interno podem ser de grande valor, mas saindo daqui não tem condições mais jogar basquetebol internacionalmente, eu posso até estar sendo duro nas minhas palavras, mas eu estou vendo globalmente como é que funciona isso daí.

Antigamente você saia daqui, não estou falando da minha geração não, tô falando da geração passada e a geração retrasada, todas as gerações. Nós íamos para os locais jogar então nós tínhamos no mínimo seis, sete jogadores de ponta, jogadores de decisão, jogadores que iam para a quadra, que eram pragmáticos, jogadores que decidiam. Hoje nós não temos nada disso, tá certo?! Porque eles são todos eles são praticamente, não sei se a palavra é omissão, entendeu?! Mas, 'já que eu tô bem aqui, para que que eu vou me arriscar mais', para que que eu vou dar um salto a mais, para que que eu vou subir um degrau a mais?' e isso é muito preocupante.

Porque você quando vai jogar internacionalmente principalmente, você precisa ser protagonista, você precisa ser o homem entendeu?! Eu tô falando isso no masculino e no feminino, não só no masculino não, então isso aí, falta muito entendeu. O jogador hoje não pensa no hoje, ele pensa no amanhã, no quanto que ele pode ganhar, os dirigentes não estão preparados para lidar com esses jogadores, os dirigentes hoje ele gente tem medo dois jogadores, a maioria deles $90 \%$ ou até mais, 
medo de perder o jogado, do jogador ir para outra equipe e jogar bem contra equipe dele que é a coisa mais idiotas do mundo.

Então eu até entendo uma montagem de uma equipe o pessoal fica preocupado em dispensar um que não está servindo naquele momento, mas que amanhã pode jogar bem contra ele. Então são tantas coisas pequenas que você fica assustado e tenho acompanhado, eu tenho aqui, tenho conversado e não é uma opinião só minha não, é uma opinião do pessoal que fala aí até mais radicalmente, porque se não tiver um trabalho de comentarista que está faltando no Brasil, de técnico e de arbitragem, quanto a arbitragem eu vou até falar uma coisa sobre a arbitragem porque ela hoje no Brasil é muito criticada, mas internacionalmente ela é muito aplaudida, sabe é uma coisa que é muito muito interessante porque, os nossos árbitros são bons árbitros, entendeu?!

Mas aqui tantas regras em cima dele tanta pressão em cima deles que eles, é mais fácil para apitar uma final de uma olímpiada, do que apitar um jogo do campeonato nacional, do NBB. É muito mais fácil! Entendeu?! Porque eles são capaz de fazer isso daí, nós temos grandes árbitros, grandes árbitros, mas você vê que eles estão perdidos, dão técnica na hora que não tem dar, discutem quando não tem que discutir e quando chega nas competições internacionais esses caras sobram porque nós temos grandes árbitros, é só você ver a NBA, a NBA hoje é uma tristeza na arbitragem.

Nós temos que mudar o conceito de treinamento, quando eu falo baseado alguma coisa, certo? Não estou falando porque eu simplesmente acho, entendeu? Antes, eu tive uma oportunidade de jogar 13 anos nos Estados Unidos e quando eu jogava aqui no Brasil antes de ir para os Estados Unidos, eu treinava praticamente umas 6 horas por dia, eu saía, namorava, tomava o meu Chopp, tudo normal, ia sempre para a cama cedo, cheguei nos Estados Unidos, primeira semana treinamento 1h45min, terminava o treinamento eu ia para casa dormir, porque eu não aguentava, eu não aguentava de tão intenso que era o treinamento, certo?! Então porque isso ai?! Qual é a duração de uma partida, em torno de 1 h45 à 2hrs, certo?!

Então você vai treinar intensamente todos os dias como se estivesse em uma partida, perfeito, então tem uma lógica nesse sentido, então depois toda a parte de aprimoramento de fundamentos só seus e que você não consegue fazer em coletividade, você pega uma bola e vai para a quadra sozinho aquilo lá. Então é uma coisa que me chamou muito atenção e hoje eu vejo os profissionais trabalhando 
estamos treinando duas vezes por dia, seis horas por dia, isso é balela isso é bobagem. O jogador não consegue mais ficar esse tempo na quadra.

Agora se você tiver incentivado, treinamento curto e forte o treino vai render muito mais. Então são conceitos que você vai aprendendo a sua vida entendeu?! Outra coisa fundamentos no Brasil, fundamentos para mim é essencial, você vê qualquer jogador da NBA eles fazem o que quiserem, aqui no Brasil nós temos um problema que o jogador não gosta de treinar fundamentos, é aquilo, eles já estão no Topo então treinar é chato.

Vou te contar mais uma historinha da minha vida, depois de jogar nos estados unidos, eu fui para a Europa jogar na Itália e foi com um técnico lugoslavo, antiga lugoslávia naquela época, ele era simplesmente o melhor técnico da Europa na época e ele assumiu a equipe no meio da temporada, fez uma reunião com a equipe, ele falou tudo bem então. Então tem só um probleminha que eu tô sentindo aqui. Então vamos treinar duas horas a noite e mais duas horas de manhã só de fundamentos, na equipe tinham três ou quatro, três jogadores titulares da seleção italiana, um americano que foi bicampeão da NBA, eleito duas vezes como sexto melhor homem, tinham 3 ex-jogador da seleção italiana, tinha eu como estrangeiro.

Então todos os dias de 9 horas às 11 horas, nós íamos treinar fundamentos, você sabe o que é fundamento, bater bolinha esquerda, direita, fazer punho, entendeu?! Fazer passe e tudo. Esse é o treinamento para um time que era considerado o melhor time da Europa.

Então você vê que os conceitos de quem que realmente quer fazer as coisas grandes continuam com os grandes personagens. Agora quem não tem condições entendeu?! Não quer passar por isso e tudo na vida é sacrifícios. Então é baseado em tudo isso que eu vivenciei que eu posso falar hoje, não é que eu sou o dono da verdade.

\section{Evolução da defesa}

A evolução da defesa, se tem uma coisa que eu aprendi é que você tem que ter uma disposição para marcar. Porque é o posicionamento da Defesa e naturalmente você tem que ensinar isso aí, mas se você não tiver disposição para marcar, para querer marcar você não vai conseguir marcar. 
Mas o que é essa evolução na defesa?! Eu não sei. Você pode ter várias formas de defesa, zona, homem, box, fazer o diabo, mas se você não tiver a disposição de marcar, certo!? Vamos te dar agora o Cleveland agora, durante o primeiro período não marcou ninguém, daqui a pouco acaba se enaltecendo porquê?! Por conta da defesa, o que que mudou?!

A vontade de jogar, a disposição, então a disposição tem que ter, ela faz parte da defesa, a mesma coisa no ataque, aquele jogo que você tem para você 'hoje eu vou lá, hoje eu vou resolver', então você cria situações para resolver o jogo, então isso é tanto na defesa quanto no ataque. Então a defesa para mim claro tem a parte dos fundamentos da Defesa, tudo o que é trabalhado para você ser um grande defensor, mas se você não tiver disposição, você vai ser mais um na quadra.

\section{Fundamentos técnicos}

Olha dentro de quadra eu não posso falar, porque eu não vejo, eu não estou lá, eu não posso chegar e falar. Mas hoje é tudo jogo de força. Tudo é jogo de força, daqui a pouco tá lá o melhor defensor do campeonato da NBB.

Ai você analisando é porque o jogador é forte da umas pancadas legais, aí a arbitragem alivia, porque o cara tem um nome legal e isso acontecem muito. Então esse jogador se torna um grande defensor, aí na verdade quando esse cara vai para um nível internacional, aí que eu falo se você estiver me entrevistando aqui para nível paulista, é uma coisa jogadores são excepcionais para nível paulista, a nível brasileiro maravilhoso, saiu daqui já não são mais.

Então eu estou jogando no máximo em ter nível internacional, que é um lugar onde todo mundo tem que planejar chegar, isso que eu falo, você pode me perguntar se tem grandes defensores aqui? Tem, mas e amanhã, isso é uma briga que eu tenho até internamente, vejo a televisão, vejo os jogos pelas televisões e um grande defensor, um grande atacante e qual o próximo passo, vai conseguir chegar lá e jogar?! Então é isso daí entendeu?! 


\section{Conhecimento do Jogo}

Eu posso falar que eu tive a maior felicidade da minha vida, eu entrei na seleção brasileira com 16 anos, aí logo depois fomos jogar o campeonato mundial na antiga lugoslávia, a nossa equipe tinha um cara chamado Wlamir Marques, Menon, Rosa Branca, Mosquico, Edvar, Sérgio Macarrão, são jogadores que você olhava e se via uma técnica perfeita, uma leitura do jogo maravilhosa.

Então você não tinha um jogador, nenhum dos jogadores, a equipe todinha era talhada para saber fazer a leitura dos jogos, tinha o Hélio Rubens, para você ver a composição dessa equipe como que era. Então essa preocupação nossa ela era tão natural e de porque todos nós temos um fundamento demais, a leitura do jogo ela vinha naturalmente e não tinha nenhum jogador ali querendo fazer 50 pontos e aparecer mais do que o outro.

Ai que eu aprendi o que era Basquetebol o que que era coletividade, o que era ajuda, depois que passei para pré-seleção eu digo até você vá até meio difícil né tem outras coisa, entendeu?!

Porque a minha história com a seleção foi muito bonita e eu não joguei praticamente, entrei em quadra em dois jogos e joguei poucos minutos, mas o envolvimento que eu tive com esse pessoal foi aonde fez eu chegar onde cheguei, só sei que eu cheguei no meu máximo, se foi bom ou se foi ruim eu não sei, mas eu sei que eu cheguei no meu máximo e eu sei disso porque até hoje eu olho para eles com admiração e respeito, então somos amigos, um sacaneia o outro o tempo todinho entendeu, mas na hora, que eu olho entendeu que você tá na mesa com Wlamir Marques, com Edvar com o Menon entendeu?! Meus olhos ficam marejados muito respeito e admiração, você não pode imaginar.

O que esses caras fizeram era grandioso era uma seleção que os caras gostavam de assistir os jogos. Depois tinha minha geração, que eu acho que foi espetacular também, entendeu?! Tinha o Carioquinha, o Adilson, o Ubiratan que foi fundamental nisso aí tudinho, super excepcional.

Então tudo isso aí eu gosto, foi muito bacana nós discutíamos com a comissão técnica, nós tínhamos uma liberdade de conversar com os técnicos em relação à equipe, não era aquele negócio de comando obsessivo que você é obrigado a fazer o que eu tô mandando, nada disso, o treinamento era uma coisa, mas isso ai não tem nada a ver com o treinamento, o comando era dele ele que manda, mas é um negócio 
de troca de ideias, troca de energias que sempre existiu e é um negócio que eu sou muito suspeito para falar, porque eu tive uma felicidade muito grande quanto $a$ isso ai entendeu?! Eu tive grandes comandantes, grandes técnicos, sempre respeitei, sempre fui respeitado. Então para mim ficou fácil de jogar Basquetebol.

\section{Ataque e defesa}

Nessa época que eu estou falando em você não tinha transição, mas o Brasil jogava muito em velocidade, tinha praticamente quem dominava a tabela era o Ubiratan, tinha uma velocidade incrível para puxar o ataque, não era bom tecnicamente, mas a disposição era fantástica. Ubiratan, abria tampinha para a esquerda ou para a direita e abria para um lado que ou tinha o Mosquito ou o Edvar, ou o Mosquito e o Wlamir sempre tinha esse pessoal que tinha velocidade, então era sempre contra-ataque, chegava no contra-ataque e não dava, esse pessoal sabia a hora de parar, esperar os jogadores, mais ligeiros podemos dizer assim, para eles fazerem a transição todinha, entendeu?!

Então, tivemos essa facilidade, que hoje em dia eu não vejo, hoje eu vejo o que?! Bola de três pontos, fantástico, mas não do jeito que jogávamos com arremessos de três pontos. Eu assisti o último jogo do NBB, teve uma hora que eu falei eu não aguento, no segundo tempo principalmente não dá para assistir.

E o pior é o mais irritante, disso ai tudinho é o jogador arremessa 10 bolas, erra as 10 , ai daqui a pouco cara faz uma de três e o cara vira fenômeno, maravilho, mas se o cara jogar lá embaixo ele também vai fazer ponto, vai sofrer falta, bonificação, vai abrir o jogo, distribuir, jogar de frente. O negócio é tão irritante simples, mas tão simples.

\section{Essencial}

Os armadores, cabeças pensantes, nós não temos isso aí hoje, até os nossos próprios armadores, temos uma hora que eles querem. Bom vou falar de armadores agora, um dos maiores armadores que eu vi na minha vida foi um jogador de um metrô e noventa, do Real Madrid e Seleção espanhola. Esse jogador tinha dias que ele fazia 2 ou 4 pontos, mas tinha dias ele fazia 40 dependendo do que ele achava dentro da 
quadra do que ele achava importante para ele ou para a equipe, eu olhava para ele e era incrível um jogador de uma inteligência fora do normal, fui jogar na Itália tinha um outro armador e eu joguei com ele, a inteligência dele era uma coisa fantástica.

Aí você vem para o Brasil você tem jogadores tô dizendo lá atrás, essa coisa todinha. Então eu acho que hoje não tem jogador inteligente dentro de quadra. Um jogador inteligente, um jogador que fale eu não vou arriscar isso aqui agora porque o meu companheiro está melhor posicionado e tem que ter essa energia, o Basquetebol é um esporte coletivo então se você não jogar coletivamente não dá para jogar.

Tem um item de uma avaliação nos Estados Unidos, eu recebi essa avaliação, tem um boletim como se fosse matemática. Na universidade tem um boletim sobre o basquetebol, ataque, defesa, e tem um negócio chamado intimidação e era o um negócio que me chamou muito a atenção, intimidação, estou jogando e eu recebo uma defesa muito dura e é como eu vou reagir a essa defesa, vou ficar inibido ou vou mostrar minha postura, vou ficar intimidado e no Basquetebol hoje você vê isso, olha o Green o LeBron James, os caras intimidam porque eles são grandes?! Não, eles querem ganhar, só olhar para os olhos deles, eles ganham milhões mais mesmo assim, voam na bola, dão o melhor, saem na porrada. Eles querem ganhar.

\section{Classificação Clássica}

Não tem muita coisa para fazer não, eu sinceramente não acho, mas eu não posso falar muito porque dentro da quadra eu não consigo dizer, porque não estou lá dentro da quadra para acompanhar os treinamentos, se eu falar qualquer coisa para você. Mas pelo o que eu vejo, não tem diferença nenhuma, tudo que fazíamos lá atrás é feito hoje em dia, talvez mais fisicamente, porque antigamente era muito mais fundamento, de você não era nem tanto físico, hoje que é físico, então você vê uma evolução na parte física, não na parte de fundamento. Então as defesas para mim não mudaram em nada, pick-and-roll essas coisas tudinho, que nós fazíamos a 30 anos atrás.

Nós tínhamos um cara chamado Carioquinha, eu digo para você uma coisa, o Carioquinha era um Gênio, nós tínhamos uma coisa, que quando ele estava apertado, nós tínhamos uma combinação chamada vermelho, o que era vermelho?! 
Quando ele gritava vermelho, eu ia aonde que ele tivesse para correr daquele porque ele estava apertado, aí eu fazia o Bloqueio e girava e ia lá para baixo, entendeu?! Hoje é o pick-and-roll e é aquele negócio lá de vermelho, o cara é tão fantástico que quem fez a primeira ponte-aérea foi ele e Zé Geraldo, eu vi eles fazendo isso em treinamento e foi excepcional, o jogador brasileiro é muito criativo.

\section{Sugestão}

Eu acredito no treinamento e no comprometimento do jogador, porque isso é uma coletividade. 


\section{ANEXO N - ENTREVISTA 14}

\section{Basquetebol Atual}

Eu acho que a defesa é fundamental é o setor mais importante, eu acho que é pela defesa que você consegue os principais resultados. Você consegue ter um time inferior tecnicamente, mas se você tiver uma defesa aplicada você consegue equilibrar um jogo contra um adversário melhor, se você tiver uma defesa aplicada se as coisas forem corretamente feitas, né?!

Eu acho que é vital, é fundamental cada vez mais a defesa. Porque antigamente o Basquete, principalmente aqui no Brasil ele ficou muito caracterizado por um ala que era um jogador que pontuava, mas se você for ver o jogo dele, ele nunca foi um grande defensor, né?!

Na verdade, não é que ele não foi um grande defensor, é que ele nunca se preocupou em defender, porque a preocupação inicial do Basquete é a, o próprio nome do jogo é Bola ao Cesto, então o objetivo é fazer, é colocar a bola dentro do cesto. Então o primeiro objetivo claro da história era você trabalhar o ataque e a defesa era pouco, não tinha tanta importância.

Hoje é justamente o contrário, então você vê os grandes times a preocupação defensiva é muito maior, a aplicação defensiva ela faz uma diferença no jogo é eu estava até lendo recentemente um negócio que um dos itens importantes da defesa que muita gente não dá é o rebote ofensivo porque se você consegue capta muitos rebotes ofensivos, você evita que seu adversário saia em velocidade, você mantêm a sua posse de bola no ataque, então quer dizer.

É uma estatística que muita gente não dá tanta atenção, a devida importância para o rebote ofensivo. A importância de você bloquear esse contra-ataque que já é o início de se pegar sua defesa desprevenida, ainda com a transição, ainda mais com o Basquete de Transição como tá, então eu acho que é fundamental o trabalho na defesa e essa preocupação, eu acho que se hoje eu fosse virar técnico 'Ah! O Bulga quer ser técnico' eu iria estudar para caramba e a minha especialização seria na defesa, a gente tem hoje o Bruno Savignani do Corinthians, é eu batendo papo com o Gustavinho semana passada, ele estava aqui que ele falou assim 'a minha preocupação é defensiva hoje', não é no ataque. 


\section{Evolução do Basquete}

Eu fiquei muito tempo vendo muito tempo como telespectador mesmo né?! Porque eu queria ser veterinário então eu não trabalhava com isso, então eu não tinha essa visão de parar para ver como é a defesa, se é individual se é zona, se é box em quatro e um em individual, um sendo em individual e essa defesa 2:3 se é matchup e tal. Eu não tinha essa preocupação aí eu olhava o jogo de Basquetebol Individualmente me chamava a atenção qualquer um que vai ver basquete e como a gente falou, que a gente foi criado nessa mentalidade de ataque, então eu via os caras que mais pontuavam.

Então me chamava a atenção um atleta da NBA, quando eu era moleque, porque era um cara que era pontuador, que era um cara que pegava e chutava independente se estava sendo marcado individualmente ou não, eu não tinha essa preocupação de ter um bloqueio ou um pick-and-roll, para mim eu não tinha, eu não via o Basquete defensivamente como grande maioria.

Mas a partir do momento que você começa a trabalhar com isso então eu posso falar, a partir do momento que eu viro comentarista, em torno de 6 anos atrás, você vê que assim, eu consigo ver bastante jogos do NBB e do Basquetebol Europeu e agora com o crescimento do NBB bastante jogos do Basquete Nacional, e eu vou te falar que assim a preocupação que existe quanto a defesa, mas se você me perguntar se ela está evoluindo a ponto assim de chamar a atenção, eu acho que não, eu acho que são variações que acontecem, eu acho que vai muito também como algo que eu li recentemente, que a defesa coletiva ela nunca pode superar a defesa individual, eu acho que o cara tem que ter uma mentalidade defensiva de ajudar o time.

Eu acho que isso pode fazer uma diferença no geral, se o jogador tem essa mentalidade defensiva vai contribuir para a defesa do time, então nos aspectos básicos como a gente sempre aprendeu e se você vai estudar um pouco de basquete você vai ver que normalmente se defende o meio, empurra o jogador para a lateral, para dificultar usa os cantos, você fecha mais o meio, você vai agrupar mais, você vai ter atenção no cara da bola, você sempre vai ter uma visão privilegiada com o cara da bola, agora se você falar assim em sistema tático, em ter uma coisa nova, eu acho que mais da mentalidade individual dos caras e de você falar de ter esses aspectos básicos bem definidos. 
Para qualquer que seja o cara grande ou o cara pequeno, porque antigamente era assim, o cara grande era o que defendia, hoje você vê é o cara do toco é o cara do roubo, mas se você tem um cara atenção por exemplo as vezes no cara da bola, porque as vezes o cara da bola hoje no Basquete moderno, é o cara que acelera jogo, você vê ai o Russel Westbrook que é um cara físico e o jogo está cada vez mais físico, então eu acho que a defesa passa a ter parte é um dos ingredientes, do Basquetebol Moderno e que você vê que está cada vez mais físico então não adianta você ter só o cara grande marcando se você não tem o cara com atleticísmo para segurar os armadores e os alas e os caras que gostam de jogar no 1 contra 1 e isso a gente vê bastante na NBA por exemplo, né?!

Então se você falar assim 'você não vê um sistema uma melhor marcação, é eu acho que não, eu não consigo ver de seis anos para cá alguma evolução, algum método que tenha sido revolucionário na parada, entendeu?

\section{Essencial}

Eu acho que depende de time, depende de adversário. Se o adversário tem um cara realmente fora de série, você vai ter que marcar o cara diferente, você vai ter que tentar incomoda-lo de uma maneira diferente, eu acho que não tem uma regra básica 'eu vou jogar dessa maneira', eu acho que a nuances, a gente viu recente um jogo Boston contra Toronto e o jogo estava muito equilibrado e o Boston tinha a vantagem, ai o Brad Stevens no último quarto utilizou uma zona 2:3 para incomodar, para causar uma dificuldade no Toronto e acabou dando certo, ai você vai falar assim 'então quer dizer que todo o jogo, zona 2:3 para qualquer adversário, esse tipo vai dar certo?' Não, não necessariamente né?!

Então depende muito do adversário, eu acho que não tem uma regra e eu acho isso que é legal isso no Basquete, porque cada ataque. Eu acho que a intensidade defensiva tem que valer por cada jogada, todas as jogadas o cara tem que ter a mesma intensidade defensiva, seja ela individual, seja ela em zona, seja ela com bastante movimentação, seja com troca e ai você vai se adequar de acordo com o seu time, a se o time tem um LeBron James, o seu time pode fazer uma marcação individual no cara e fazer o restante me diamante, em quatro, é posicionamento diferente é em quatro e ai eu deixo para os técnicos e não para o comentarista. 
O comentarista tem que analisar o que está acontecendo e o que eles estão querendo causar de dano para o Franchise Player ou para o Grande Jogador de diferente que o cara vai ter que mudar, vai ter que sair da sua zona de conforto para mudar o jogo, esse é o grande detalhes isso na minha opinião, essa é minha visão como comentarista.

Eu não vou me apegar tanto ao que que os caras estão fazendo 'ah eles mudaram isso, ah eles mudaram aquilo', é logico que é importante em um determinado momento do jogo você perceber que ele saiu de uma individual e se moveu para uma zona 2:3, de fechar de diminuir de isolation nos caras saber que em um momento mais agudo ainda mais agora em playoff, que sabe que na reta final a bola vai ser na mão de um ou dois no máximo, que o time sabe que é um DeMar DeRozan que vai decidir e então você se dedicar, fechar espaço para poder diminuir o índice de aproveitamento do cara entendeu.

Eu acho que não tem uma regra, eu acho que você pode usar de acordo com o adversário, de acordo com o momento, até para não ficar 'a o seu time só joga em zona 2:3' você fica marcado por isso, você pode ser o melhor zona 2:3 da vida, você pode ser um monstro, só que o grande técnico defensivo, por exemplo aquele assistente, como você pode ver hoje o Tom Theabodeau começou como técnico assistente do Boston ele era assistente técnico defensivo e quando ele vai para o Chicago e ele é técnico o Chicago em três ou quatro temporadas é o melhor time de defesa da liga porquê?

Porque a mentalidade dele é a defensiva, então hoje existem caras especialistas em fazer defesa, especialistas em montar o time no ataque e eu acho que essa que é a variação, isso que é o importante, você ter especialistas em cada setor e poder ajudar da melhor maneira e não ficar engessado e não ficar previsível, isso serve para a defesa que é o nosso caso e no ataque, porque não adianta você atacar sempre da mesma maneira porque ai cara vai defender de um jeito 'porque assim ó, acabou'.

Vão criar uma dúvida, você tem que criar essa dúvida no adversário. 


\section{Classificação clássica}

Para uma nomenclatura normalmente você colocar esses quatro grupos, mas sabendo que existem há ramificações em cada uma delas, 'a tem a mista com quatro e um fixo, um out' como eu falei, quatro em box, quatro em diamante, três em diamante e dois presos, eu acho que as variações existem dentro dessa nomenclatura, acho que a nomenclatura é mais fácil para você dividir porque também não dá para você ramificar em várias e eu acho que você fazendo dessas quatro que está bem definido como você mesmo falou já é uma coisa antiga e vai ser mantido isso por muito tempo e você ramificar essas ai eu acho que é o interessante, agora nesse momento eu acho que não tem o porquê você alastrar ainda mais é você ter a noção de que existem esses quatro tipo e que cada uma delas com exceção da individual que é mais individual mesmo e não tem muito o que fazer é você criar as variações dentro das outras duas, de pressão, pressão no cara da bola. 